09-3

\title{
House Prices and Risk Sharing
}

\author{
by Dmytro Hryshko, University of Alberta, María José Luengo-Prado \\ Northeastern University and NEPPC Visiting Scholar, Bent E. Sørensen , \\ University of Houston and CEPR
}

\begin{abstract}
We show that homeowners are able to maintain a high level of consumption following job loss or disability in periods of rising house values. However, the consumption drop for consumers who simultaneously lose their job and equity in their houses is substantial. Using data from the Panel Study of Income Dynamics, we verify that homeowners smooth consumption more than renters, and that consumption smoothing improves when houses appreciate in the area of residence. We calibrate and simulate a model of endogenous homeownership and home-equity loans, and show that the model is able to reproduce the patterns in the data quite well.
\end{abstract}

This paper was written while María José Luengo-Prado was a visiting scholar at the New England Public Policy Center. The author's email address is: $\underline{\text { m.luengo@neu.edu }}$

This version: August 25, 2009 


\section{Introduction}

Many countries, including the United States, have experienced large fluctuations in house values over the last decade. For example, Providence, R.I., saw a 75 percent gain in home prices from 2001 to 2005, while Los Angeles, on the opposite coast, saw a gain of 91 percent according to the Federal Housing Finance Agency (FHFA). ${ }^{1}$ However, Providence house prices declined by 10 percent from 2006 to 2009, while those of Los Angeles fell even more, by 20 percent. As housing is the largest asset for most families, such swings are associated with large swings in the net worth of typical consumers, and it is of first-order importance to understand the impact of such fluctuations on consumption.

In this paper we show that rising house values help homeowners maintain their level of nondurable consumption after income losses. Unfortunately, during recessions such as the current subprime crisis, the drop in consumption can be severe for homeowners who simultaneously lose employment and housing equity. Our point estimates - combined with data on house prices - imply that a 10 percent drop in household income (relative to aggregate trend) will be associated with a 3 percent drop in nondurable consumption in Providence during 2006-2010, while a similar drop would have been associated with a 7 percent rise in consumption during 2001-2005. ${ }^{2}$ The deceleration in consumption growth will be even larger in cities such as Los Angeles, and the depreciation of house prices is likely to provide a severe drag on the recovery of the aggregate U.S. economy from the subprime crisis.

We use data from the Panel Study of Income Dynamics (PSID) to study consumption changes following the onset of disability or job loss stemming from displacement (arguably exogenous shocks to income). We investigate households' ability to maintain —or "smooth"consumption in the face of such shocks, but focus on deviations from countrywide fluctuations, or "risk sharing." Risk sharing is interesting per se, but focusing on risk sharing also allows us to abstract from a host of difficult-to-control-for aggregate variables that may affect consumption, such as the aggregate interest rate. Our main contribution is to study how risk sharing varies with house prices by matching PSID data and house price data at the metropolitan level from the FHFA. We focus on house-price appreciation rather than the level of house prices because house-price appreciation is an exogenous shock to homeowners' collateral. ${ }^{3} \mathrm{We}$ find that homeowners maintain relatively higher (lower) levels of nondurable consumption after job displacement or disability when house values increase (decrease).

To interpret our findings, we calibrate and simulate a model designed to capture the main features of homeownership - in particular the dual role of housing as a shelter and an asset. Furthermore, homeownership is endogenous in our model, which features finitely lived households with preferences for housing (shelter) and nondurable consumption. Housing services can be obtained either in the rental market or through homeownership, but buying or

\footnotetext{
${ }^{1}$ This agency was formerly known as the Office of Federal Housing Enterprise Oversight.

${ }^{2}$ These numbers are calculated using Table 2, column (1). House prices are based on first-quarter data, and house depreciation is assumed to be 0 from 2009 to 2010 .

${ }^{3}$ The PSID has information on household house equity, but these data are questionable for our purpose, because household-level equity is likely to be endogenous to risk aversion or other preference parameters that may affect consumption directly.
} 
selling a house requires payment of a proportional commission. Housing equity above a minimum down payment can be used as collateral but there are no un-collateralized loans. Households adjust (nondurable, non-housing) consumption, and possibly housing, in response to (exogenous) income fluctuations.

We perform panel-data regressions on the simulated data in the same fashion as we estimate our empirical relations using real data. We compare the estimated parameters from the data and from model simulations, and - to the degree that magnitudes match between actual and simulated data - interpret our empirical findings. Our simulations show that homeowners withstand income shocks better than renters. Further, the ability to weather income shocks increases significantly for homeowners when the relative price of housing increases. Our model leaves out many real-world complications. Nonetheless, we find that the predictions of the model match the results from the PSID well. We do not attempt to structurally fit our model, as in Li, Liu, and Yao (2009), who have a different focus but use a model similar to ours. The disadvantage of our approach, compared with their paper, is that we cannot test the model, and we discuss mainly the quantitative predictions regarding the impact of the shocks that match our empirical focus. The advantage is that our findings are robust to many forms of model misspecification.

Our empirical approach is related to work that has attempted to measure the direct impact of house values on consumption - typically under the label of "wealth effects" of house-price changes. Because national house prices correlate with economic conditions in general, the quantification of the effect of house prices on consumption remains controversial. The most promising avenue seems to be regressions that rely on regional house prices as pioneered by Attanasio and Weber (1994) — such regressions allow the authors to control for nationwide effects. Further, these authors simulate a theoretical model to evaluate the theoretical plausibility of their empirical estimates. Two recent papers in that vein are Campbell and Cocco (2007), who find evidence of a wealth effect, and Attanasio, Blow, Hamilton, and Leicester (2009), who argue that common causality is a more likely explanation for the patterns of consumption and house-price growth in the United Kingdom. Like these authors, we compare renters to owners, and, more briefly, young households to old households.

Our paper is also related to papers that examine "collateral effects" of house-price appreciation. This literature investigates whether rising house prices alleviate credit constraints for homeowners who can gain access to housing capital through refinancing or home-equity lines of credit. Of particular relevance is Hurst and Stafford (2004), who document that house equity is used as a mechanism to smooth income shocks. This work complements ours, because their empirical focus is on the decision to refinance while our work directly considers consumption. We do not attempt to identify credit-constrained households, because most indicators of credit constraints, such as outstanding debt or net worth, are endogenous to households' decisions, and our strategy is to use variables that can be considered exogenous. Of course, homeownership status is clearly endogenous, which is why we explicitly compare our empirical results to those predicted by our model. We show that our results are robust to the inclusion of (endogenous) wealth in the robustness section. 
Our paper is also related to Lustig and Van Nieuwerburgh (2004), who find, using aggregate data, that there is more risk sharing between U.S. metropolitan areas in periods when average U.S. house-price appreciation is high. ${ }^{4}$

We explain our empirical strategy in the next section, and describe the data and report our empirical estimation results in the third section. We present our theoretical model and its implications in the fourth section, and report the results of regressions using simulated data in the fifth section. The sixth section concludes.

\section{Regression specification}

In an endowment economy with one nondurable good, perfect Arrow-Debreu markets, and constant relative risk aversion utility, all consumers will have identical consumption growth rates. Mace (1991) tested this prediction in a panel-data regression of consumption on income with controls for aggregate effects.

Let $c_{i t}=\log c_{i t}-\log c_{i, t-1}$ be consumption growth for individual $i$ in year $t$ and $y_{i t}$ be income growth, defined analogously. Let $\bar{z}_{t}$ be the period $t$ specific mean of any generic variable $z$. We subtract the time-specific mean from all variables. Subtracting the aggregate nondiversifiable component then gives all estimated coefficients the interpretation of showing the impact on deviations from perfect risk sharing. Let $X_{i t}$ be a vector of controls (age, the square of age, and family size). The coefficient $\alpha$ in the panel-data regression:

$$
c_{i t}-\bar{c}_{t}=\mu+\alpha\left(y_{i t}-\bar{y}_{t}\right)+\left(X_{i t}-X_{t}\right)^{\prime} \delta+\varepsilon_{i t}
$$

can be interpreted as a measure of deviation from full risk sharing: if individual consumption growth rates are identical, the coefficient $\alpha$ will be 0 . Alternatively, if consumption of agent $i$ follows income perfectly, the coefficient $\alpha$ would be unity.

This specification also has the advantage that we can study consumption in a setting where the subtracted time average captures the potential impact of a host of aggregate variables that may affect consumption - in particular, the nationwide interest rate. We typically estimate equation (1) for owners and renters separately. In either case, the average of, say, income growth is calculated over the full sample of both renters and owners. This implies that we are examining deviations from perfect risk sharing between U.S. residents (at least to the extent that the PSID mimics the U.S. population). If we alternatively subtracted the time average for renters separately, the interpretation would be a test of risk sharing between renters.

Pooling data from regions with different house-price appreciation, we can capture the effect of house-price growth on risk sharing by interacting income changes with house-price changes. We run regressions of the form:

\footnotetext{
${ }^{4}$ Lustig and Van Nieuwerburgh (2004) consider the role of housing collateral in a general equilibrium model with state-contingent claims. However, they do not consider renters versus homeowners, and they do not perform econometric analysis using micro data.
} 
$c_{i t}-\bar{c}_{t}=\mu+\alpha\left(y_{i t}-\bar{y}_{t}\right)+\beta\left(h_{m t}-\bar{h}_{t}\right)+\gamma\left(y_{i t}-\bar{y}_{t}\right) \times\left(h_{m t}-\bar{h}_{t}\right)+\left(X_{i t}-X_{t}\right)^{\prime} \delta+\varepsilon_{i t}$

where $h_{m t}$ is the $\log$ difference in house prices in the metropolitan area where individual $i$ lives, while $\hbar_{t}$ is the mean $\log$ difference in house prices for all metros at time $t$. With this additional interaction term, $\gamma\left(y_{i t}-\bar{y}_{t}\right)\left(h_{m t}-h_{t}\right)$, the risk-sharing measure becomes $\alpha+\gamma\left(h_{m t}-h_{t}\right)$, and a non-zero value of $\gamma$ indicates that the amount of risk sharing is a function of metro house prices.

A negative value of $\gamma$ implies less sensitivity of consumption to idiosyncratic income-that is, more risk sharing when houses appreciate. It is essential for this interpretation that average income each time period is subtracted in the interaction, because risk sharing is measured as the sensitivity of $c_{i t}-\bar{c}_{t}$ to $y_{i t}-\bar{y}_{t}$. In equation (2), the time-varying coefficient to $y_{i t}-\bar{y}_{t}$ is $\alpha+\gamma\left(h_{m t}-\hbar_{t}\right)$. By subtracting $\hbar_{t}$ from $h_{m t}$, we remove the nationwide average house-price appreciation from the time-varying coefficient. We do this because the time-series variation in average house prices is likely correlated with other aggregate variables, such as stock market performance, and we want to hedge against the possibility that house prices will spuriously capture the effect of such variables.

We further examine the impact of job displacement. Let $D_{i t}$ be a dummy variable taking the value 1 if the head of household $i$ suffers displacement, and 0 otherwise. We examine the impact of job loss on consumption and the risk-sharing role of housing in the face of job displacement by estimating the relation:

$c_{i t}-\bar{c}_{t}=\mu+\alpha\left(y_{i t}-\bar{y}_{t}\right)+\beta\left(h_{m t}-\bar{h}_{t}\right)+\xi\left(D_{i t}-D_{t}\right)+\zeta\left(D_{i t}-D_{t}\right) \times\left(h_{m t}-\bar{h}_{t}\right)+\left(X_{i t}-X_{t}\right)^{\prime} \delta+\varepsilon_{i t}$.

Here, the derivative of idiosyncratic consumption growth with respect to displacement shocks is $\xi+\zeta\left(h_{m t}-h_{t}\right)$, and a positive coefficient of $\zeta$ implies that house-price appreciation dampens the effect of displacement on consumption growth - that is, risk sharing goes up with house prices. We also examine the effect of disability, captured by an indicator variable denoted by $L$, in an analogous fashion.

Empirical estimations

\section{Data}

We use individual- and household-level data from the PSID, which is a longitudinal study of a representative sample of U.S. households. This study started in 1968 and follows families over time, including young adults as they split off from the original family units. Combined with low attrition rates, this has meant that the sample size grew from 4,800 families in 1968 to more than 7,000 families in 2001, despite the fact that the study dropped some families in 1997 for cost reasons. In 1997 the PSID also changed from interviewing annually to interviewing biennially. 
The PSID data files provide a wide variety of information about both families and individuals collected over the span of the study. The central focus of the data is economic and demographic, with substantial detail on income sources and amounts, employment, family composition changes, and residential location. Information gathered in the survey applies to the circumstances of the family unit as a whole (such as type of housing), or to particular persons in the family unit (such as age and earnings). While the study collects some information about all individuals in the family unit, the greatest level of detail is ascertained for the primary adults heading the family unit.

The PSID maintains Geocode Match Files, which contain the identifiers necessary to link the main PSID data to Census data. Using the Geocode Match Files allows us to add data on characteristics of each respondent's neighborhood to the already rich array of socioeconomic variables collected in the PSID. ${ }^{5}$ In our work, we match households to their Metropolitan Statistical Area (MSA) of residence, and we use house-price appreciation measures at the metropolitan level.

As a measure of consumption we use food consumption, because of a lack of broader consumption aggregates, although we also show results for imputed nondurable consumption. Food consumption consists of food consumed at home and food consumed away from home (excluding food purchased at work or school). There was a change in the wording of the questionnaire in 1994: the PSID reported annual food costs until 1993, but has reported costs at the daily, weekly, biweekly, monthly, or annual frequency since 1994. For the years 19942005, we use household food consumption reported at the monthly or weekly frequency and convert those records to annual amounts. ${ }^{6}$ The household income measure used is the sum of real labor and transfer income of head and wife before taxes. We deflate food consumption at home and away from home by their respective price indices (from the Bureau of Labor Statistics), and income by the overall Consumer Price Index (CPI).

When constructing our displacement dummy, we consider a household head to be displaced if the head's "previous company folded/changed hands/moved out of town; employer died, went out of business," because of "strike, lockout," or because the head was "laid off/fired."7 The disability variable is constructed from two questions typically referred to as "limiting conditions." The first asks: Do "you (head) have any physical or nervous condition that limits the type of work or amount of work you can do?" The second question asks: "How much does it limit your work?" We assume the head is disabled if he or she answers yes to the first question, and indicates that the disability limits his or her ability to work somewhat or a lot. If the head answers yes to the first question and reports that the condition limits work a little, we

\footnotetext{
${ }^{5}$ The Geocode Match data are highly sensitive (usually pinpointing the census tract in which families live), and are available only under special contractual conditions designed to protect the anonymity of respondents.

${ }^{6} \mathrm{We}$ lose a low number of observations for households reporting food consumption at other frequencies. We do not include them in our sample because some, when converted to annual amounts, are clear outliers.

${ }^{7}$ The PSID did not collect information on displacement during the 1994-1997 waves.

${ }^{8}$ In 1973, 1974, and 1975, only new heads were asked these questions. In cases where the answer in one of those years is missing, we impute it using the answer from a preceding year.
} 
consider the head not to be disabled. We consider the head to be disabled if he or she answers yes to the first question, and further states: "can do nothing."

Because the PSID data (in particular, food consumption) are noisy at the annual frequency, we use four-year (overlapping) growth rates. This choice reduces measurement error and averages out temporary fluctuations in income and consumption. Economists typically agree that longer-lasting ("permanent") shocks matter more for welfare, so little is lost by looking at the longer frequencies, where permanent shocks are relatively more important. ${ }^{10}$

The four-year frequency complicates the construction of our disability and displacement indicators somewhat. In our growth regressions, the disability variable enters as 0 if there was no change in the disability status from period $t-4$ to $t$, as 1 if the head reports disability at $t$ but not at $t-4$, and as -1 if the head reports disability at $t-4$ but not at $t$. The displacement variable enters as 1 if the head reports being displaced in year $t-3, t-2, t-1$, or $t$. When presenting results by housing tenure status, we define a homeowner as a household that owned a house in all periods involved in calculating the consumption growth rate, and analogously for renters.

We should mention that in the PSID, the timing of several variables is not fully synchronized. The earnings and employment questions are designed to elicit information for the previous calendar year. For example, the income record in a survey year $t$ refers to the income earned in period $t-1$; the same holds for displacement status. Since most households are interviewed in the first quarter of the year, we assume that food consumption and limiting status records in a survey year $t$ refer to the food consumption and limiting status effective in period $t-1$. Similarly, demographic variables such as age and family size recorded in a survey year $t$ are assumed to correspond to the head's age and family size in period $t-1 .{ }^{11}$ The house-price index in year $t$ is the house-price index reported for the first quarter of the year.

Our sample selection procedure is as follows. For each year, we keep observations with nonzero and non-missing reports of food consumption at home. To hedge against outliers, we drop observations above the 99th percentile and below the 1st percentile of the annual food-athome distributions. We further set to missing the records of food away from home above the 99th percentile of each annual distribution. ${ }^{12}$ We then add up real food at home and food away from home to obtain a measure of total food consumption. We drop observations with missing records for head's labor income, and also observations with a ratio of total food consumption to income above the 99th percentile or below the 1st percentile of the annual distributions for the ratio. We also drop observations above the 99th percentile and below the 1st percentile of the four-year income growth and consumption growth distributions. We restrict our analysis to families with stable composition and a head of household of prime age (25-65), and for which

\footnotetext{
${ }^{9}$ Our results are similar if we use the answers to the first question only.

${ }^{10} \mathrm{We}$ choose an even number of years to match up with the biennial sampling frequency initiated by the PSID in 1997.

${ }^{11}$ This is necessary to enable us to keep observations after 1997, when the PSID switched to biennial data collection.

${ }^{12}$ We do not drop observations with zero records of food away from home. In the Consumer Expenditures Survey, which provides reliable information on the spending patterns of U.S. consumers, virtually everyone reports non-zero records of food at home, while a substantial fraction of respondents reports zero expenditures on food away from home (excluding food at work).
} 
we have information on housing status. ${ }^{13}$ We must also restrict our sample to households that reside in the same metropolitan area during a given four-year period, so that we can meaningfully assign to them four-year house-price changes in their MSA. ${ }^{14}$

\section{House-price appreciation}

To construct a measure of house-price appreciation, we use house-price indices at the MSA level published by the FHFA, which reports quarterly house-price indices for single-family detached properties. The agency bases these reports on data on conventional conforming mortgage transactions obtained from the Federal Home Loan Mortgage Corporation (Freddie $\mathrm{Mac}$ ) and the Federal National Mortgage Association (Fannie Mae).

The house-price indices are based on the methodology proposed by Case and Shiller (1989). Quarterly house-price indices are reported for the nation, the nine U.S. Census divisions, the 50 states (plus the District of Columbia), and MSAs and divisions. The index for each geographic area is estimated using repeated observations of housing values for individual single-family residential properties on which at least two mortgages were purchased or securitized by either Freddie Mac or Fannie Mae since January 1975. We focus on changes in metro-level house prices, which can be assumed to be exogenous for individual households. We deflate house values by the overall CPI.

When merging FHFA house-price indices with PSID data, we end up with a sample that covers the period 1980-2003. This period includes housing booms and busts. Figure 1 shows the distribution of real house-price appreciation (four-year growth rates to match our empirical specification) over the period. The overall mean (four-year) house-price appreciation is 6 percent, with a 19 percent standard deviation. Median house-price appreciation is lower at 4 percent. As is evident from the distribution, our sample includes both house-price appreciation and house-price depreciation episodes.

There is rich variation across MSAs and over time. The mean of average house appreciation by MSAs is just 3 percent, with a 5 percent standard deviation. Three of the MSAs with the lowest house-price appreciation during the period are Binghamton, Houston, and New Orleans, which have a mean (standard deviation) appreciation of -7.7 (13.5), -5.7 (14.5), and -3.3 (13.4) percent, respectively. Three of the MSAs with the highest house-price appreciation are Boston, San Francisco, and the New York City area, at 15.3 (28.2), 14.7 (22.9), and 11.5 (24.5), respectively (see panel [a] of Figure 2). Figure 2, panel (b), depicts the evolution of MSA house-price appreciation over time for selected MSAs. The figures provide clear evidence of important differences across MSAs.

\section{Estimation results}

We estimate the regressions described above. We show results estimated by a two-stage PraisWinsten GLS procedure, which is efficient in the case of first-order autocorrelation-our

\footnotetext{
${ }^{13}$ In the PSID, a small category of households in each wave is recorded as neither owners nor renters. Since it is not clear which group these households are most likely to belong to, we do not consider them in our empirical analysis.

${ }^{14}$ Our data exclude the Latino sample of the PSID, because it was added in 1990 and then discontinued in 1995.
} 
observations are overlapping and therefore, by construction, autocorrelated - or by instrumental variables estimation, where household income is instrumented..$^{15}$ In either case, the standard errors are calculated using robust clustering at the MSA level.

Table 1 presents summary statistics. The range of four-year log differences of consumption is between about -1.7 and 1.7, while that of income is even larger. House prices also show large deviations from the U.S. average. On average, about 12 percent of the sample receives a displacement shock during a four-year time span, while 6 percent suffers from a limiting condition and 4 percent recovers from one.

Table 2 shows the results of our main regression specification for the sample that pools homeowners and renters. We find, in all specifications, a very strong effect on food consumption from changes in family size, with an increase in family size leading to higher food consumption. This result is intuitive, and we will not comment on this variable any further. The elasticity of food consumption with respect to income is about 12 percent, while the elasticity of food consumption with respect to house prices varies from 12 to 14 percent, depending on the specification. The estimated effect of house-price appreciation on consumption is large and highly significant. The sensitivity of consumption to house prices is of obvious policy relevance, but we hesitate to stress this result, because it may be spurious for a number of reasons. For example, house prices in a region are correlated with personal income, and while we control for personal income in the leftmost three columns, average house prices may well be more correlated with permanent components of income. In that case, the "house-price effect" would still pick up an income effect. Alternatively, house prices may be correlated with expectations of future income (we come back to this issue below).

Our first approach to examining risk sharing is to check whether the effect of income on consumption is weaker when houses appreciate. The negative coefficient to the interaction of house prices and income points to significant risk sharing from house-price appreciation. The coefficient of -0.127 indicates that consumption would not react to the income loss at all in a period when house prices double. ${ }^{16}$

As noted, it is hard to untangle correlations between house prices and income in an area, and we therefore shift the focus to job displacement and disability, which are less likely to correlate with aggregate variables such as house prices. In the second column of Table 2, we examine the effect of job displacement. We see that consumption drops significantly, on the order of 4.7 percent, when the head of household experiences job displacement. This effect is mitigated when house prices go up. In fact, house-price appreciation of about 40 percent would be enough to keep consumption unchanged, according to our estimates for the full sample. (In our calculations we disregarded the own effect of house-price appreciation on consumption.)

The third column in Table 2 considers disability, which we interpret as having similar effects on earnings as displacement. (We therefore do not have separate simulations for

\footnotetext{
${ }^{15}$ Our data will have autocorrelation of order higher than one, but typically most efficiency gains are obtained as long as first-order correlation is allowed for.

${ }^{16}$ We approximate doubling house prices with a unity change in log-house prices and find $0.124-0.127 \approx 0$.
} 
"displacement" and "disability" in our theoretical section.) Displacement may potentially correlate with house prices in a state with a large concentrated industry, such as car manufacturing in Michigan: bad times for the automotive industry could lead to large-scale displacement and dropping house values. ${ }^{17}$ Disability is unlikely to correlate with other variables. However, compared with displacement, disability could give less significant results, because it is often the result of a gradual loss of earnings ability — see Stephens (2001). We find a similar pattern for disability, with the main effect of disability being strongly significant, but its interaction with the house-price growth is not statistically significant.

In columns (4) and (5) of Table 2, we drop income growth from our regressions. We observe larger negative effects of displacement and disability on consumption growth, because part of the effect is typically captured by declining income when income is included in the regression. In the last column, both disability and displacement and their interactions with house-price appreciation are included. We observe that these variables have such low correlation with each other that the point estimates are virtually the same as when the variables are included one by one.

Our results for the full sample may mask important heterogeneity of consumption responses to income changes, disability, and displacement shocks among owners and renters. Tables 3 and 4 summarize the results of regressions for the separate samples of homeowners and renters, respectively. Renters are almost twice as sensitive to income changes as owners - the coefficient to income growth is 0.095 for owners versus 0.176 for renters. This is consistent with the fact that owners are better able to insure food consumption than renters. However, because housing tenure is a choice variable of the consumer, this result could be due to unobserved differences between owners and renters. For owners, total food consumption drops by as much as 2.9 to 4.6 percent when the household head experiences displacement or disability. The interactions of disability and displacement variables with house-price growth are positive and quite precisely estimated, indicating higher risk sharing for owners when houses appreciate. In fact, houses have to appreciate about 26 (12) percent to absorb the adverse effect of displacement (disability) on food consumption of owners.

Renters experience a somewhat larger drop in consumption relative to owners when the head experiences displacement or disability. If the significant interaction terms for owners are due to the fact that housing equity alleviates credit constraints, we should not find similar effects for renters. In Table 4, we see that the interactions for displacement and disability are indeed not significant for renters at anything near normal levels of significance. Surprisingly, house prices themselves are highly significant for the consumption of renters, likely because of correlations with components or predictors of income. ${ }^{18}$ For our study, the important result is that we do not observe increases in risk sharing for renters when house prices change, but we do for homeowners. To determine the generality of our results, we perform a battery of robustness checks next.

\footnotetext{
${ }^{17}$ However, most of the variation in our sample is from layoffs, not from firm closings.

${ }^{18}$ Even in the absence of correlations with income, forward-looking renters may react to house prices. For instance, if they have saved for a house that becomes out of reach because of appreciation in house prices, they may spend these savings on nondurables. Such effects are likely not large, but this needs to be evaluated by model simulations.
} 


\section{Robustness analysis}

\section{Non-overlapping growth rates}

We run our regressions with non-overlapping growth rates by using data from 1980, 1984, 1990, 1994, 1999, and 2003. That approach decreases the sample size considerably, from 24,776 observations for owners and renters combined to 8,641. ${ }^{19}$ Table 5 reports the results, which are very similar to our findings (if not stronger) when we used overlapping growth rates. To reiterate, we observe risk sharing increasing for owners but not for renters when homes appreciate. Given the similarity of the results, we continue the rest of the analysis with the larger baseline sample.

\section{House-price residuals}

In an attempt to disentangle the correlation between house-price growth and income growth, we repeat the analysis, but use the residuals from a regression of (real) MSA house-price appreciation on (real) MSA income growth as our measure of house-price growth. ${ }^{20}$ The results are presented in Table 6 . While this approach lowers the estimated coefficients for house-price growth for both renters and owners (from 0.131 to 0.114 for owners, and from 0.149 to 0.115 for renters, in the specification without income growth), it does not eliminate the somewhat anomalous and significant "house-price effect" for renters. ${ }^{21}$ Importantly, all other coefficients in the regressions barely change. From now on, we use these residuals as our measure of house-price appreciation.

\section{IV regressions}

One further concern is that income may be endogenous to the desired consumption level. While we have tried to address this issue by focusing on the effect of arguably exogenous displacement and disability shocks, we also report results instrumenting for income. As instruments, we use the log income difference at the MSA level, and the (year-by-year) average log income difference (calculated from PSID data) of individuals with the same educational level, and in the same broadly defined cohort as the respondent, excluding the respondent. ${ }^{22}$

Table 7 shows the first-stage estimation. Both MSA income and average income are strong predictors for household income, with coefficients of 0.55 and $0.22(0.58$ and 0.26$)$, and tstatistics of about 7 and 5 (4 and 3) for owners (renters), while displacement and disability have clear negative effects on income.

\footnotetext{
${ }^{19}$ Food consumption data are unavailable in 1988 and 1989.

${ }^{20}$ The R-squared of the regression of house-price appreciation on income growth is 0.12 , and the coefficient to MSA income growth is estimated at 0.94 with a standard error of 0.03 .

${ }^{21}$ This is consistent with the claim in Attanasio, Blow, Hamilton, and Leicester (2009), who estimate that wealth effects often capture left-out variables that affect house prices and consumption simultaneously.

${ }^{22}$ We construct four year-of-birth cohorts and three educational groups. Our cohorts are defined for households with heads born in 1915-1929, 1930-1944, 1945-1959, and after 1959. Our educational groups are: high school dropouts (those with less than 12 years of education), high school graduates (those with more than 11 but less than 16 years of education), and college graduates (those with at least 16 years of education).
} 
The second-stage IV results are displayed in Table 8 . We find a coefficient to income growth of about 0.47 for owners and 0.56 for renters - see columns (1) and (4). These coefficients are significantly higher than their OLS counterparts, because our instruments are mainly correlated with the permanent-income component. In the IV regressions, the "house-price effect" for renters is no longer significant, while the effect remains for homeowners at about half the size. When income is instrumented, the direct effects of displacement and disability are not statistically different from zero, but the interaction terms are still clearly positive for owners and not for renters. (The interaction for disability is significant at the 5 percent level for owners, while that of displacement is close to significance at the 10 percent level.) Importantly, the coefficients for owners and renters are statistically different from each other. Overall, the results of these regressions deliver the same message: higher risk sharing for owners and no additional risk sharing for renters when houses appreciate.

\section{Young and old households}

Table 9 summarizes our results when we divide the sample by age. We classify households as "young" if their head is aged 40 or younger, and "old" if the head is over age 50 . Both groups represent roughly 35 percent of our total sample (heads in our sample are aged 25-65).

The elasticity of food consumption with respect to income is lowest for old homeowners, at about 9 percent, compared with 13 percent for young owners. There is no significant difference in the income elasticity of consumption for young and old renters. However, the income elasticity of consumption for both is clearly higher - at about 18 percent - than that for either group of owners: even young owners are able to smooth food consumption better than renters. The "wealth effect" is higher for old than for young owners (12 versus 10 percent), and we still estimate a positive effect of similar magnitude of house prices for young renters and old owners. The coefficient is no longer significant for old renters. That could reflect the fact that the correlation between house prices and expectations on future income vary by age, or it could simply be a result of the small sample size for old renters. Not surprisingly, displacement and disability have a stronger direct effect on old households than on young households (and more so for renters than for owners). This is intuitive, because old households may have lower chances of finding a new job of similar quality once they become displaced, and of recovering when becoming disabled.

Returning to the main focus of our study, we find that the interaction of displacement with house-price growth is nearly significant for old owners, in the direction of better risk sharing when prices go up. The interaction of the disability indicator with house-price growth is positive and precisely estimated for old homeowners, and negative and significant for young renters. That is, the latter group has less risk sharing when house prices go up when facing a disability shock. This finding is intuitive, as we argue that these interaction terms are mainly capturing a collateral effect, and old homeowners are likely to have accumulated more home equity.

\section{Food at home versus food away}

We also study the effect of house prices on risk sharing of the two components of food consumption: food at home and food away. Food away from home may be considered a luxury, and it should, therefore, have a higher income elasticity than food at home. Also, 
consumers should be more willing to tap home equity to maintain the consumption level of food at home than that of food away.

Table 10 shows lower elasticities of food consumption at home relative to total food consumption for both owners and renters. We also find a significant effect of house-price appreciation for both groups of consumers. The estimated interaction terms show that rising home values clearly help homeowners smooth consumption of food at home when they encounter displacement or disability. For renters, food at home drops substantially when the household is hit by a displacement shock, or when income drops. Insignificant interaction terms indicate that house prices play no role in smoothing renters' consumption.

When considering food away from home, in Table 11, we find that the income elasticity of this food component is larger than that of food at home, as expected. We do not find a significant effect of house prices on food away from home for either group. The effect of displacement on food away is estimated to be large both for homeowners and renters-about three times larger than the effect on food at home. Households appear to first cut their eating outside the home when the head loses his/her job. Disability also leads to a bigger reduction of food away than of food at home. In this case, the interaction terms are insignificant for both groups, indicating no role of house-price appreciation in risk sharing for this expenditure component.

In summary, the estimated coefficients to the interaction terms robustly point to the fact that homeowners are better able to maintain consumption of food at home when they lose jobs or become disabled if homes appreciate, which is not the case for food away.

\section{Other robustness tests}

Appendix A presents some additional robustness tests. Briefly, our results are similar if we use imputed nondurable consumption instead of food consumption, or if we use disposable income instead of income before taxes. We also consider whether our results might be capturing differences in household liquid wealth by splitting our sample by wealth level. Importantly, the interactions of displacement and disability with house-price growth are insignificant for renters of all wealth levels. This indicates that the house-price variable is not standing in for differences in wealth.

We also analyze the impact of household access to consumer installment loans on risk sharing. We find higher consumption growth for renters when credit is expanding. However, these types of loans do not seem to help either renters or owners smooth consumption when they face displacement or disability shocks - perhaps because these loans tend to dry up when consumers face adverse conditions. In either event, these results indicate that house prices are not a stand-in for regional credit conditions.

The model and calibration

To better interpret our results and control for possible selection bias, we introduce a model and perform regressions using simulated data from the model of the same form as those performed on the PSID data. An important feature of our model is that we explicitly consider homeownership as a choice for households (i.e., an endogenous tenure choice). Because we 
argue that the differential effect of house prices on consumption risk sharing for owners and renters is likely capturing a collateral effect, we need a model in which houses serve as collateral for loans.

We follow Díaz and Luengo-Prado (2008), and consider a life-cycle model where households derive utility from consumption of a nondurable good and housing services that can be obtained in a rental market or through home ownership. When purchasing a house, households must provide a down payment and pay transactions costs, while housing equity above a certain threshold can be used as collateral for loans. We allow for preferential tax treatment on owner-occupied housing, as in the U.S. tax system. Households face uninsurable earnings risk and uncertainty arising from changing house prices. We describe the details of the model next.

\section{The model}

\section{Preferences, endowments, and demography}

Households live for up to $T$ periods and face an exogenous probability of dying every period. During the first $R$ periods of life, they receive stochastic labor earnings, and at period $R$ households retire and receive a pension. When a household dies, it is replaced by a newborn. Households are not altruistic toward their offspring but may die with wealth, which is passed to the newborn as an accidental bequest. Houses are liquidated at death, so newborns receive only liquid assets as bequests.

Households derive utility from nondurable goods, and from housing services obtained from either renting or owning a home. One unit of housing stock provides one unit of housing services. The per-period utility of an individual of age $t$ born in period 0 is $u\left(c_{t}, s_{t}\right)$, where $c$ stands for nondurable consumption, and $s$ denotes housing services. Households cannot rent and own a home at the same time. The expected lifetime utility of a household born in period 0 is:

$$
E_{0} \sum_{t=0}^{T} \frac{1}{(1+\rho)} \zeta_{t} u\left(c_{t}, s_{t}\right)
$$

where $\rho \geq 0$ is the time discount rate and $\zeta_{t}$ is the probability of being alive at age $t$.

\section{Market arrangements}

A household starts any given period $t$ with a stock of residential assets, $h_{t-1} \geq 0$, deposits, $d_{t-1} \geq 0$, and collateral debt (mortgage debt and home-equity loans), $m_{t-1} \geq 0$. Deposits, meant to capture financial assets in general, earn a return $r_{t}^{d}$. Debt carries an interest payment at the rate $r_{t}^{m}$. There is no uncertainty about interest rates. Households buy the house that renders services in period $t$ at the beginning of the period. The price of one unit of housing stock in period $t$ (in terms of nondurable consumption) is $q_{t}$, while the rental price of one unit of housing stock is $r_{t}^{f}$ $-f$ denotes the housing stock rented. 
When buying a house, households must make a down payment, $\theta q_{t} h_{t}{ }^{23}$ This means that a new mortgage must satisfy the condition:

$$
m_{t} \leq(1-\theta) q_{t} h_{t}
$$

For homeowners who do not move in a given period, houses serve as collateral for loans (home-equity loans) with a maximum loan-to-value ratio of $(1-\theta)$. Thus, households can tap housing equity through a home-equity loan at no additional cost, but (5) must still be satisfied. If house prices go down, a homeowner who is "upside down" on a mortgage can simply service debt if he or she is not moving. In other words, as long as the homeowner stays in the same house, $m_{t}$ could be higher than $(1-\theta) q_{t} h_{t}$ if $m_{t}<m_{t-1}$. This situation can last as many periods as the household desires, but foreclosure is not allowed. ${ }^{24}$

Households must pay a fraction $\kappa$ of the house value when buying a house, which may be interpreted as a sales tax or a search cost. When selling a house, a homeowner loses a fraction $\chi$ of the house value, which may be interpreted as brokerage fees. Houses depreciate at the rate $\delta^{h}$, but if full maintenance is done, the house does not depreciate. However, households have some flexibility regarding how much maintenance to do in a given period. Specifically, buying and selling costs are paid if $h_{t}<\left(1-\delta^{h}\right) h_{t-1}$, which indicates the household is downsizing (beyond depreciation), or if $h_{t}>h_{t-1}$, which means the household is trading up. ${ }^{25}$

In this setup, households may want to sell their houses for various reasons. First, selling the stock is the only way to realize capital gains beyond the maximum loan-to-value ratio for home-equity loans. Second, households may want to increase or downsize housing consumption throughout the life cycle. Third, households may want to take advantage of relatively cheaper rental prices. On occasion, they may need to liquidate this asset to prop up nondurable consumption after depleting their deposits and maxing out home-equity loans. Households may also be forced to sell their houses as they are subject to an idiosyncratic moving shock, $z_{t}$. This shock is meant to capture the effect of "geographical" mobility stemming from job change, and of demographic shocks not modeled for simplicity.

\footnotetext{
${ }^{23}$ We abstract from income requirements for people purchasing houses. Many lenders follow the rule of thumb of "three times income" in determining the size of mortgages. However, the empirical literature finds that wealth constraints are more important than income constraints when people purchase a home. See, for example, Linneman, Megbolugbe, Watcher, and Cho (1997), or Quercia, McCarthy, and Watcher (2000).

${ }^{24}$ These assumptions simplify the computation of the model while allowing us to consider both down-payment requirements and home-equity loans without modeling specific mortgage contracts or mortgage choice. See Li and Yao (2007) for an alternative model with refinancing costs, and Campbell and Cocco (2003) for a discussion of optimal mortgage choice.

${ }^{25}$ Results are robust to alternative formulations of the adjustment costs, such as pure maintenance or pure depreciation. Our specification, which is in between the two, is slightly easier to implement computationally with a discrete grid.
} 


\section{The government}

The government taxes income, $y$, at the rate $\tau_{y}$. Interest payments on mortgages and homeequity loans are deductible from the income base. The deduction percentage is denoted as $\tau_{m}$. Moreover, imputed housing rents for homeowners are tax-free. Then, taxable income in period $t$ is $y_{t}^{\tau}=y_{t}-\tau_{m} r_{t}^{m} m_{t-1}$. The entire proceeds from taxation are used to finance government expenditures that do not affect individuals at the margin.

\section{Earnings and house-price uncertainty}

Households are subject to household-specific risk in labor earnings and house-price risk common to residents of the same region. For working-age households, labor earnings, $w_{t}$, are the product of permanent income and a transitory shock $\left(P_{t}\right.$ and $v_{t}$, respectively):

$w_{t}=P_{t} v_{t}$ and $P_{t}=P_{t-1} \gamma_{t} \varepsilon_{t} S_{t}$.

$\Delta \log P_{t}$, is the sum of a non-stochastic life-cycle component $\operatorname{logg}_{t}$, an idiosyncratic permanent shock, $\log \varepsilon_{t} \sim N\left(-\sigma_{\varepsilon}{ }^{2} / 2, \sigma_{\varepsilon}{ }^{2}\right)$, and a displacement shock, logs, which reduces permanent income with a small probability $p\left(s_{t}=\lambda \prec 1\right.$ with probability $p$ and 1 , otherwise). The displacement shock is meant to capture employment and/or disability shocks that affect income for more than one period. (That is, we do not have disability and displacement separately in our regressions with simulated data, as we do in the regressions with PSID data.) The idiosyncratic transitory shock is $\log v_{t} \sim N\left(-\sigma_{v}{ }^{2} / 2, \sigma_{v}{ }^{2}\right)$.

Retirees receive a pension proportional to permanent earnings in the last period of their working life. For a household born at time $0, w_{t}=b P_{R}, \forall t>R .^{26}$

Housing prices are uncertain and, following Li and Yao (2007), we assume that house-price appreciation is an i.i.d. normal process: $q_{t} / q_{t-1}-1=\mathrm{Q}_{t}$, with $\mathrm{Q}_{t} \sim N\left(\mu_{\mathrm{e}}, \sigma_{\mathrm{Q}}^{2}\right)$. This specification implies that house-price shocks are permanent. ${ }^{27}$

\section{Calibration}

Our calibration is constructed to reproduce three statistics from the Survey of Consumer Finances: the homeownership rate, the median wealth-to-earnings ratio for working-age households, and the median ratio of home value to total wealth for homeowners ( 70 percent, 1.8 , and .82 , respectively).

\footnotetext{
${ }^{26}$ This simplification is required for computational reasons and is common in the literature. See, for example, Storesletten, Telmer, and Yaron (2004).

${ }^{27}$ This assumption is common in the literature (e.g., Cocco 2005; Campbell and Cocco 2003), and greatly simplifies the computation of the model by facilitating a renormalization of the household problem with fewer state variables.
} 
To match the targets, we choose three parameters: the discount rate, $\rho$, the weight of housing in the utility function, denoted by $1-\alpha$, and the value of the smallest house (relative to the annual value of permanent income) homeowners can purchase, $\underline{\tilde{\underline{h}}}$ (3.15 percent, .2, and 1.65 , respectively). The general strategy in choosing the remaining parameters is to focus, whenever possible, on the empirical evidence for the median household (see Appendix B for details, and Table 12 for parameter values).

\section{Patterns of homeownership and wealth}

Figure 3 depicts the evolution of some key variables throughout the life cycle in our baseline calibration. All series are normalized by mean earnings. Panel (a) shows mean labor income (earnings for workers and pensions for retirees) and nondurable consumption. For workingage households, the life-cycle profile for earnings is calibrated to the profile estimated by Cocco, Gomes, and Maenhout (2005) for households with a high school degree. Earnings peak at age 47 . For retirees, the pension-replacement ratio is calibrated to be 50 percent of permanent earnings in the last working period. Our model produces a hump-shaped nondurable consumption profile with a peak around age 60 .

Panel (b) in Figure 3 depicts mean wealth and its different components throughout the life cycle. Total wealth is hump-shaped and peaks at ages 60-63, with a value about 2.96 times mean earnings in the economy, declining rapidly afterward. Because we do not allow for altruism in the model, total wealth is zero for those who reach the oldest-possible age (not depicted). Housing wealth (including collateralized debt) increases until age 52-55, then stays fairly constant until it begins to decrease at age 72 , when the homeownership rate starts to decline. Financial assets become negative at age 72 as retirees take advantage of reverse mortgages.

The targets of our calibration are the overall homeownership rate in the United States, the median wealth-to-earnings ratio for working-age households, and the median ratio of house value to total wealth for homeowners. Figure 4 plots the life-cycle patterns of these three variables against the data. ${ }^{28}$ The median wealth-to-earnings ratio in the model - see panel (a) - follows the ratio in the data very closely until age 59, and diverges significantly thereafter, probably because we are not allowing for heterogeneity in retirement ages. In our model, gross housing wealth is a higher (lower) fraction of total wealth than in the data for the oldest (youngest) cohorts. The fact that we are abstracting from intergenerational altruism (that is, older cohorts exhaust their assets as they age) may account for the divergence for the oldest households. Other possibilities are limited availability of reverse mortgages in real life, or uncertainty about health expenses in old age, which may result in higher liquid savings. The timing of accidental bequest (received early in life in the form of liquid wealth) could explain the divergence for the youngest cohorts.

Panel (b) in Figure 4 depicts the life-cycle profile of homeownership rates in our benchmark calibration and in the data. Although we can reproduce the average U.S. homeownership rate, our model underestimates homeownership for ages 24 to 40 , and overestimates

\footnotetext{
${ }^{28}$ We use data from the Survey of Consumer Finances (averages from 1989 to 2004) instead of the PSID for these graphs, because the SCF has somewhat better information on wealth, and the sample sizes are larger, which are advantageous when examining different age groups.
} 
homeownership rates for older cohorts, with the exception of the oldest. In our benchmark calibration, the oldest cohort turns to renting in the last period of life, to free forced housing equity in the form of the down payment, which is not the case in the data.

It seems we would need further heterogeneity and/or additional assumptions to exactly replicate homeownership patterns and other profiles by age. However, this is not the focus of our paper. Our aim is to determine if our empirical findings are consistent with a story in which housing equity is used to alleviate liquidity constraints. To this end, we study the quantitative predictions of this model (with the key features of endogenous tenure choice and a collateral role for housing) regarding the effect of house-price changes on risk sharing.

Simulation

We simulate 27 "regions" with 5,000 people each for a number of periods. House-price shocks are common to all individuals in a given region (there are only three possible house-price shocks), while all other shocks (income and moving shocks) are idiosyncratic. We set up the simulations so that in regions 1 through 9, the house-price shock is the lowest value for the last four periods (house-price depreciation). In regions 10 through 18, the house-price shock is the middle value (constant house prices), while in regions 19 through 27, the house-price shock is the highest value (house-price appreciation). The results we present are calculated using the last five periods of the simulations (which represent 10 years, as one period in our model corresponds to two years) ${ }^{29}$

\section{Regression results from simulated data}

To match the specification in our empirical section, we use four-year log differences in consumption, income, and house prices, and overlapping growth rates in the regressions. Our displacement dummy is equal to 1 in period $t$ if the household suffers a displacement shock in periods $t, t-1, t-2$ or $t-3$. As in the data, when presenting results by tenure status, we define a homeowner as a household that owned a house in all periods involved in calculating the consumption growth rate. We define renters analogously. To facilitate comparisons with our empirical results, we restrict our attention to households with heads aged 28-64. (As explained in Appendix B, households are born at age 24 and retire at age 66.) Table 14 , column (1), shows that the propensity to consume is 0.17 , on average, and that consumption grows significantly with house-price appreciation. According to column (2), a 10 percent house-price appreciation would result in a 1.5 percent increase in consumption. The sensitivity of consumption to income changes goes down when houses appreciate, as shown by the estimated negative coefficient for the interaction term in column (2).

The third column reveals a clear drop in consumption in the face of displacement, in addition to that captured by income, of about 17 percent. The third column also shows a positive term to the interaction of house-price growth with displacement, indicating more risk sharing when houses appreciate. In other words, in periods of house-price appreciation, consumption changes correlate less with income changes than in periods of house-price depreciation.

\footnotetext{
${ }^{29}$ Results are not very different if we include more periods in our regressions, so we keep the sample smaller for tractability.
} 
In Table 15, we consider the results for owners and renters, respectively. Renters react much more strongly to income than owners do (the marginal propensity to consume is 0.13 for owners and 0.29 for renters). Owners appear to use house equity to smooth consumption, as in the data. The increase in risk sharing following house-price appreciation (a negative $\gamma$ ) is estimated with very high statistical significance for owners but not for renters. Most importantly, we observe a significant impact of risk sharing when measured as the interaction of house prices with displacement for homeowners, an effect that is not present for renters.

Table 16 summarizes the model's predictions when we split the sample by age. As in the empirical part, we classify households as young if their head is aged 40 or younger, and old if the head is over age 50. The result we want to stress is that the effect of house-price appreciation on consumption (in the direction of more risk sharing) is strongest for old owners, who are more likely to have accumulated home equity, as in the data.

When comparing the size of the estimated coefficients in the data and in the model, we see some discrepancies. First, the MPCs out of income are larger in the simulated data, particularly for renters. That is, on average, there is more risk sharing in the actual data, or income is measured with error. Our model assumes only one type of liquid asset that brings interest income: safe bonds. In the real world, asset income comes in many forms that often are not measured well. In particular, capital gains were large and variable during the period we consider. Also, individuals share risk with family members and through various ethnic, religious, and other networks, which we do not model, and which may account for lower marginal propensity to consume (MPC) in reality. While measurement error in income and the availability of alternative risk-sharing mechanisms not considered in the model could explain this difference, another possibility is a bequest motive, which we consider next. Second, in the model, house-price appreciation increases the consumption of owners and has no effect on the consumption of renters, while in the actual data we estimate a significant house-price effect for renters. We argue that the latter may be picking up an income effect (that is, a correlation of house prices with income components or predictors of income). Also, the estimated wealth effect for owners is higher in simulated data than in PSID data, which could be due to the fact that extracting equity out of the house is costless in our model. ${ }^{30}$ Third, compared with the data, the estimated effect of displacement shocks is significantly larger. As shown in Appendix B, this can be easily "fixed" if we allow some displacement shocks to be transitory and some to be permanent without affecting other estimated coefficients. Finally, the estimated coefficients for the interaction terms of house-price growth and income shocks are substantially larger in PSID data.

To check the robustness of our main finding - the fact that house-price appreciation significantly increases risk sharing for homeowners and not for renters - and to see if we can improve the fit of the model, we proceed to consider some extensions of our model suggested by our empirical results.

\footnotetext{
${ }^{30} \mathrm{We}$ will not explore this issue further here, because computationally it is very costly to include a refinancing cost.
} 


\section{Model extensions}

We consider two main extensions: (1) correlation of house prices with income, assuming perfect correlation between a regional income shock and house-price shocks; and (2) the effect of warm-glow bequests, which may motivate seniors to hold on to their housing stock or housing equity, and may bring the MPCs for income closer to those in the data. To compare results more easily, we recalibrate parameters so that in all scenarios we have the same overall homeownership rate, median wealth-to-earnings ratio for working-age households, and median ratio of house value to total wealth for homeowners.

Table 17 displays the parameters for alternative model specifications, and Appendix B provides a few more details on the new assumptions. Appendix B also discusses results using a CES utility function instead of the benchmark Cobb-Douglas. Our results are barely affected by this choice once the model is recalibrated: it shows just slightly lower MPCs for both owners and renters with CES when housing and nondurables are complements. Our intuition for this finding is that in the presence of adjustment costs, homeowners do not have the flexibility to adjust housing consumption rapidly to changes in relative prices. ${ }^{31}$

\section{Comparisons with the baseline case}

Figure 5 illustrates the life-cycle profile for homeownership with and without correlations between income and house prices. With a positive correlation, homeownership is lower for the youngest cohorts and higher for the older cohorts (the model is calibrated to produce the same overall homeownership ratio in both scenarios). Houses are less useful for smoothing income shocks, and because the down-payment constraint tends to bind for the younger and poorer households, these households postpone homeownership. If parameters were not recalibrated, the overall home ownership rate would simply be lower.

Table 18 shows results for four alternative calibrations. Some interesting patterns emerge. For example, with a positive correlation between income and house price, house-price appreciation has a stronger effect on consumption growth. In fact, the so-called house-price effect is even statistically significant for renters: this is capturing expectations about future income. While we do not claim that our parameterization is necessarily very good in terms of matching reality, these results highlight that it is "tricky business" to estimate the wealth effect of house-price appreciation in general. House prices are not set in a vacuum, and will correlate with components of income or possibly with other important variables, such as the probability of current or future job loss.

Comparing the cases with a bequest motive with the baseline of accidental bequests, we observe a significantly lower MPC for renters when a bequest motive is at play. This is intuitive because, in the absence of a bequest motive, poor consumers (typically renters) would spend a higher fraction of increases in income. Importantly, our house-price interaction terms are consistently significant for owners, with a sign indicating risk sharing, while that is not the case for renters.

\footnotetext{
${ }^{31} \mathrm{See} \mathrm{Li,} \mathrm{Liu,} \mathrm{and} \mathrm{Yao} \mathrm{(2009)} \mathrm{for} \mathrm{a} \mathrm{structural} \mathrm{estimation} \mathrm{of} \mathrm{household} \mathrm{preferences} \mathrm{over} \mathrm{housing} \mathrm{and}$ nondurables.
} 
The regressions on simulated data leave us with one puzzle we have not been able to solve. While the sign of the interaction terms matches well between the data and the model, the estimated coefficient of the interaction term is much larger in the data. This poses a puzzle that awaits future research.

\section{Conclusion}

In a calibrated theoretical model in which agents can own or rent, we show that homeowners are better able to share income risks than renters. Using household-level data from the PSID, and house price data from the FHFA, we find that U.S. households are significantly better able to maintain their level of consumption after job loss or disability if they are homeowners in regions where housing is appreciating. Our interpretation is that this results from homeowners' improved collateral.

The coefficients we estimate are of economically significant magnitudes. For example, if we ignore potential wealth effects, a homeowner who becomes disabled will see a drop in consumption of about 4 percent over a four-year period if house prices are constant, but no change in consumption if house prices in the metro area increase by about 15 percent during the same time period. However, if house prices are dropping by, say, 40 percent - as is not uncommon in the wake of the 2008 subprime crisis - a staggering consumption drop of 14 percent can be expected for a homeowner who becomes disabled. ${ }^{32}$

\footnotetext{
${ }^{32}$ This illustration is based on the coefficients in column (5) of Table 3.
} 


\section{References}

Attanasio, O. P., L. Blow, R. Hamilton, and A. Leicester. 2009. "Booms and Busts:

Consumption, House Prices, and Expectations." Economica 76(301):20-50.

Attanasio, O. P., and G. Weber. 1994. "The UK Consumption Boom of the Late 1980s: Aggregate Implications of Microeconomic Evidence.” Economic Journal 104(427):12691302.

Blundell, R., L. Pistaferri, and I. Preston. 2008. "Consumption Inequality and Partial Insurance." American Economic Review 98(5):1887-1921.

Campbell, J., and J. F. Cocco. 2003. "Household Risk Management and Optimal Mortgage Choice.” Quarterly Journal of Economics 118(4): 1149-1194.

Campbell, J. Y., and J. F. Cocco. 2007. "How Do House Prices Affect Consumption?

Evidence from Micro Data," Journal of Monetary Economics 54(3):591-621.

Case, K., and R. Shiller. 1989. "The Efficiency of the Market for Single-Family Homes." American Economic Review 79: 125-137.

Cocco, J. F. 2005. "Portfolio Choice in the Presence of Housing." Review of Financial Studies 18(2):535-567.

Cocco, J. F., F. J. Gomes, and P. J. Maenhout. 2005. "Consumption and Portfolio Choice over the Life Cycle." Review of Financial Studies 18(2):491-533.

Díaz, A., and M. J. Luengo-Prado. 2008. "On the User Cost and Homeownership.” Review of Economic Dynamics 11(3):584-613.

Díaz, A., and M. J. Luengo-Prado. 2009. “The Wealth Distribution with Durable Goods." International Economic Review, forthcoming.

Feenberg, D., and E. Coutts. 1993. “An Introduction to the TAXSIM Model.” Journal of Policy Analysis and Management 12(1):189-194.

Goetzmann, W. N., and M. I. Spiegel. 2000. "The Policy Implications of Portfolio Choice in Underserved Mortgage Markets." Working paper no. 00-18. New Haven, CT: International Center for Finance, Yale School of Management.

Gruber, J. W., and R. F. Martin. 2003. "Precautionary Savings and the Wealth Distribution with Illiquid Durables." International finance discussion paper no. 773. Washington, DC: Board of Governors of the Federal Reserve System.

Harding, J. P., S. S. Rosenthal, and C. Sirmans. 2007. "Depreciation of Housing Capital, Maintenance, and House Price Inflation: Estimates from a Repeat Sales Model.” Journal of Urban Economics 61(2):193-217.

Hendricks, L. 2001."Bequests and Retirement Wealth in the United States.” Mimeo, Arizona State University.

Hurst, E., and F. Stafford. 2004. "Home Is Where the Equity Is: Mortgage Refinancing and Household Consumption." Journal of Money, Credit, and Banking 36(6):985-1014. 
Li, W., H. Liu, and R. Yao. 2009. "Housing over Time and over the Life Cycle: A Structural Estimation.” Working paper no. 09-7. Research Department, Philadelphia Federal Reserve Bank.

Li, W., and R. Yao. 2007. "The Life-Cycle Effects of House Price Changes." Journal of Money, Credit and Banking 39(6):1375-1409.

Linneman, P., I. F. Megbolugbe, S. F. Watcher, and M. Cho. 1997. "Do Borrowing Constraints Change U.S. Homeownership Rates?” Journal of Housing Economics 6(4):318333.

Luengo-Prado, M., and B. E. Sorensen. 2008. "What Can Explain Excess Smoothness and Sensitivity of State-Level Consumption?" Review of Economics and Statistics 90(1):65-80.

Lustig, H., and S. Van Nieuwerburgh. 2004. "How Much Does Household Collateral Constrain Regional Risk Sharing?” Working paper no. 10505. NBER.

Mace, B. J. 1991. "Full Insurance in the Presence of Aggregate Uncertainty." Journal of Political Economy 99(5):928-956.

Munnell, A. H., and M. Soto. 2005. "What Replacement Rates Do Households Actually Experience in Retirement?" Working paper no. 2005-10. Boston, MA: Center for Retirement Research, Boston College.

Prescott, E. C. 2004. "Why Do Americans Work So Much More Than Europeans? Federal Reserve Bank of Minneapolis Quarterly Review, July, 2-13.

Quercia, R. G., G. W. McCarthy, and S. F. Watcher. 2000. "The Impacts of Affordable Lending Efforts on Homeownership Rates.” McLean, VA: Federal Home Loan Mortgage Corp.

Sinai, T., and N. S. Souleles. 2005. "Owner-Occupied Housing as a Hedge against Rent Risk." Quarterly Journal of Economics 120(2):763-789.

Stephens, M. 2001. "The Long-Run Consumption Effects of Earnings Shocks." Review of Economics and Statistics 83(1):28-36.

Storesletten, K., C. Telmer, and A. Yaron. 2004. "Consumption and Risk Sharing over the Life Cycle.” Journal of Monetary Economics 51(3):609-633. 
Appendix A. Further Robustness Analysis

\section{Disposable income}

We repeat our analysis using changes in household disposable income to control for shocks to household income flows stemming from changes in the tax code. We use the TAXSIM tool at the National Bureau of Economic Research (NBER) to obtain a consistently estimated measure of taxes on head's and wife's labor incomes. We then subtract tax obligations from our income measure to obtain household disposable non-financial income. (The PSID computed head's and wife's combined federal income taxes from 1970 up to 1991, but we do not use these data because our sample extends well beyond 1991.)

Results are presented in Table A-1. The estimated coefficients to income growth are slightly higher both for renters and owners relative to the estimated coefficients in Table 6 . This is consistent with theoretical predictions, because a higher fraction of shocks to disposable income is passed on to consumption. Importantly, the results for displacement and disability shocks, and their interactions, are virtually the same for this income measure.

\section{House prices and risk sharing of total nondurable consumption}

Much of the theoretical and empirical research in this area focuses on the response of total nondurable consumption to income changes. Although the PSID does not collect measures of total nondurable consumption, Blundell, Pistaferri, and Preston (2008) impute nondurable consumption of PSID households in a study of the joint dynamics of consumption and income inequality in the United States. Using data from the Bureau of Labor Statistics' Consumer Expenditure Survey (CEX) for 1980-1992, these authors estimate a structural equation for food consumption as a function of nondurable consumption and demographics, and invert the estimated equation to obtain a measure of nondurable consumption for PSID households. We follow their imputation strategy here. We use extracts of the CEX for 1980-2002 from the NBER.

In the CEX, households report at most four quarterly observations on consumption components. We use data for households that respond in all four quarters, and that are complete income reporters. The first report of consumption may be in different quarters and months of a quarter. If household consumption is recorded in both years $t$ and $t+1$, we assume that annual consumption refers to year $t$ if that year contains at least six months of consumption records, and to year $t+1$ otherwise. In the PSID, heads are males in households with couples, while in the CEX heads are considered to be those who rent or own the unit of residence. To make the definitions of heads compatible, we assume that heads are males in the CEX families with couples. We drop households whose heads are part-time or full-time college students. As in our selection rules for the PSID sample, we drop observations for households with zero or missing records for food consumption at home. We further trim the annual distributions of food at home below the 1st and above the 99th percentiles, and the annual distributions of food away from home above the 99th percentile (as in our PSID sample). Our final CEX sample contains households whose heads are 25-65 years old and born between 1915 and 1978. Our measure of nondurable consumption is the sum of annual 
expenditures on food at home, food away from home, food at work, alcohol and tobacco, clothes and personal care, domestic services, transportation (such as gasoline, tolls, and insurance), airfares, entertainment, gambling and charity, business services, life insurance, and utility payments.

In the first column of Table A-2, we report the results of an OLS regression of food consumption on our measure of nondurable consumption, demographic controls, and prices. Note that food consumption, as in the PSID, is the sum of food at home and food away from home, while nondurable consumption, besides food at home and food away from home, includes food at work. The expenditure elasticity of food consumption is high in the 1980s, and drops steadily to about 0.61 in 2002 . However, the estimated elasticities may be biased because of measurement error in nondurable consumption, and because of endogeneity of food and nondurable consumption. We therefore follow Blundell, Pistaferri, and Preston (2008), and instrument log nondurable consumption (and its interactions with year and education dummies) with the year-by-year averages of the head's and wife's log hourly real wages (and their interactions with year and education dummies).

The results are presented in the second column of Table A-2. The estimated elasticity in 2002 is higher, at about 0.8. We do not find a discernible trend in the estimated elasticities in the IV regression, as was found in the OLS regression, and by Blundell, Pistaferri, and Preston (2008). When we include rent payments and imputed rent for homeowners in our measure of nondurable consumption, we obtain results similar to those in Blundell, Pistaferri, and Preston (2008) (the third and fourth columns of Table A-2). In the IV regression, the expenditure elasticity of food consumption is high in the 1980s (about 0.89 ), and declines to about 0.78 in 2002.

Because our simulation model separates non-housing consumption and housing services, we use the estimated coefficients in the second column of Table A-2 (based on the consumption measure, which excludes housing services) to impute nondurable (non-housing) consumption to PSID households for 1980-2002. This time span is shorter than that used in our previous food regressions, and as a result our samples are smaller.

In Table A-3, we report the results for (imputed) nondurable consumption. The response of nondurable consumption to income growth is a bit higher than the response of food consumption -0.116 versus 0.095 for owners, and 0.204 versus 0.176 for renters. This is consistent with the theory, as the response of food consumption to income changes is equal to the product of the expenditure elasticity of food, estimated to be below 1, and the response of nondurable consumption to income changes. The response of nondurable consumption to house-price growth is also slightly higher. For owners, nondurable consumption drops in the event of the head's displacement or disability. For renters, nondurable consumption drops substantially if the head becomes displaced, and less so when the head becomes disabled. The interactions of the displacement shocks with house-price growth are not precisely estimated. However, even for this smaller sample, we find that the risk of disability is better shared for owners in times of house-price appreciation. 


\section{Wealth-rich versus wealth-poor}

Although we eliminate the effect of economy-wide fluctuations in stock prices by taking out the aggregate component in our empirical regressions, house-price appreciation may still be correlated with appreciation of household portfolios. If that is the case, one would expect the interactions of house-price growth with disability or displacement to be significant for renters with high initial liquid wealth.

In Table A-4 we analyze this, presenting our main regressions for samples of owners and renters who are "wealth-rich" or "wealth-poor." The measure of initial liquid wealth we use is household total net worth, excluding business wealth and the value of housing in 1984 (the earliest record on wealth in the PSID). We split households into two samples. Households whose liquid wealth in 1984 is above the 60th percentile of the liquid wealth distribution are labeled wealth-rich households. Households whose liquid wealth in 1984 is below the 40th percentile of the wealth distribution are labeled wealth-poor. We further split those two samples into samples of owners and renters. We find that wealth-rich owners are the least sensitive to income shocks, while wealth-poor renters are the most sensitive. Importantly, the interactions of displacement and disability with house-price growth are insignificant for the poor and rich samples of renters. We conclude that it is unlikely that the estimated effects of our interactions are contaminated by some unmeasured shocks to household liquid wealth.

\section{Credit conditions on installment loans}

We also analyze the impact of consumer installment loans on risk sharing. We construct a measure of credit conditions for these loans using the quarterly Senior Loan Officer Survey on Bank Lending Practices. This survey, conducted by the Federal Reserve Board, includes some 60 large domestic banks and 24 U.S. branches of foreign banks. We use a variable that captures the net percentage of respondents that indicate more willingness to make consumer installment loans. To match the quarterly frequency of the data to our four-year growth rates, our measure on credit conditions is a moving average of the last 12 quarters at a given point in time. We focus on consumer installment loans because, unlike home-equity loans, they are available to both homeowners and renters.

Table A-5 reports the results from regressions that, like those in the main text, include interaction of credit conditions with displacement and disability shocks, rather than interactions with house-price growth. We find that credit conditions for installment loans do not seem to have an effect on homeowners. For renters, we find higher consumption growth when credit is expanding. However, these loans do not seem to help renters smooth consumption when they experience displacement or disability shocks, perhaps because these loans tend to dry up when consumers are facing adverse conditions. ${ }^{33}$

\footnotetext{
${ }^{33}$ Our variable for credit conditions is for the aggregate United States, while our house-price interaction is the MSA-specific deviation from aggregate house-price appreciation. Our discussion assumes that the effect of potential MSA-specific credit conditions would be similar to the results here.
} 
Appendix B. The Household Problem and Calibration

\section{The household problem}

The problem solved by a newborn at time 0 can be written as:

$$
\max _{\left\{c_{t}, f_{t}, h_{t}, d_{t}, m_{t}, x_{t}\right\}_{t=0}^{T}} E_{0} \sum_{t=0}^{T} \frac{1}{(1+\rho)^{t}} \zeta_{t} u\left(c_{t},\left(1-x_{t}\right) f_{t}+x_{t} h_{t}\right),
$$

subject to

$$
\begin{aligned}
& c_{t} \geq 0, f_{t} \geq 0, h_{t} \geq 0, d_{t} \geq 0, m_{t} \geq 0, x_{t} \in\{0,1\}, z_{t} \in\{0,1\}, \forall t=0, \ldots, T, \\
& c_{t}+\left(1-x_{t}\right) r_{t}^{f} f_{t}+d_{t}-m_{t}+x_{t}(1+I \kappa) q_{t} h_{t}+x_{t-1} I \chi q_{t}\left(1-\delta_{h}\right) h_{t-1}+\tau_{y} y_{t}^{\tau} \leq \\
& w_{t}+\left(1+r_{t}^{d}\right) d_{t-1}-\left(1+r_{t}^{m}\right) m_{t-1}+x_{t-1} q_{t}\left(1-\delta_{h}\right) h_{t-1}, \forall t=0, \ldots, T, \\
& w_{t}=P_{t} \nu_{t}, \quad P_{t}=P_{t-1} \gamma_{t} \epsilon_{t} s_{t}, \quad \forall t \leq R . \quad w_{t}=b P_{R}, \forall t>R, \\
& y_{t}^{\tau}=w_{t}+r_{t}^{d} d_{t-1}-\tau_{m} r_{t}^{m} m_{t-1}, \forall t=0, \ldots, T, \\
& m_{t} \leq(1-\theta) q_{t} h_{t} \text { or } m_{t}<m_{t-1} \text { if } m_{t}>(1-\theta) q_{t} h_{t} \text { and } h_{t}=h_{t-1}, \\
& \forall t=0, \ldots, T-1 ; m_{T}=0,
\end{aligned}
$$

Equation (A-2) contains non-negativity constraints, and states that households cannot be renters and homeowners at the same time ( $x_{t}$ is an indicator of homeownership in period $t$ ), and face moving shocks. Equation (A-3) is the budget constraint, where $I$ is an indicator function equal to 1 if the household is moving, and 0 otherwise. Equation (A-4) describes labor income for working-age households, and the pension benefit for retirees. Equation (A-5) spells out taxable income. Equation (A-6) is the collateralized debt constraint, which says that the maximum loan-to-value ratio for new mortgages and equity lines of credit is $1-\theta$, allowing for an exception for non-movers who can simply pay their mortgage. Finally, equation (A-7) captures the dynamics of housing prices.

Under these assumptions, households prefer equity to debt financing of their houses (i.e., they pay their mortgages before accumulating deposits), as long as the after-tax rate on mortgages, $\left(1-\tau_{m} \tau_{y}\right) r_{t}^{m}$, is higher than the after-tax return on deposits, $\left(1-\tau_{y}\right) r_{t}^{d}$. For details on the solution method, see Díaz and Luengo-Prado (2009). 


\section{Calibration details}

\section{Preferences, endowments, and demography}

For computational reasons, one period is two years. Households are born at age $24(i=1)$, and die at the maximum age of $85(i=31)$. The retirement age is $66(i=22)$. Survival probabilities are taken from the latest U.S. Vital Statistics (for females in 2003), published by the National Center for Health Statistics. The implied fraction of working-age households is 75.6 percentslightly lower than the fraction in the PSID, 78.6 percent. Most parameters are quoted in annual terms, but are adjusted to a biennial frequency in our calculations.

For preferences regarding consumption of nondurable goods and housing services, we choose the non-separable Cobb-Douglas utility function:

$$
u(c, s)=\frac{\left(c^{\alpha} s^{1-\alpha}\right)^{1-\sigma}}{1-\sigma}
$$

The risk aversion parameter is $\sigma=2$.

We follow Cocco, Gomes, and Maenhout (2005) in our labor earnings calibration. Using data from the PSID, those authors estimate the life-cycle profile of income, as well as the variance of permanent and transitory shocks, for three different educational groups: no high school, high school, and college. We choose these authors' estimates of the variance of permanent and transitory shocks for households whose head has a high school degree - the typical median household (0.01, and 0.073, respectively). These values are typical in the literature: see Storesletten, Telmer, and Yaron (2004). For consistency, we also use the estimated growth rate of the non-stochastic life-cycle component of earnings for a household with a high school degree from Cocco, Gomes, and Maenhout (2005).

To calibrate the displacement shock, we follow the evidence in Stephens (2001). The literature on job displacement finds that annual earnings fall 25-40 percent in the year of displacement, while earnings fall by roughly 15 percent after a disability shock. Annual earnings are well below expected levels six years after the initial shock in both cases. Since we model displacement as a permanent shock, we set the income loss from the shock toward the lower end of these findings: 25 percent (i.e., $\lambda=0.75$ ). The probability of the displacement shock is 3 percent, a bit below the 5-15 percent found using datasets such as the PSID. (Numbers vary depending on the specific definitions of displacement and disability.) Cocco, Gomes, and Maenhout (2005) do not allow for a displacement shock, so $\sigma_{\varepsilon}{ }^{2}$ is adjusted so that the overall variance of the permanent component inclusive of the disability shock is their estimate, .01 . We have tried other combinations of displacement probabilities and income losses from the shock and our main results are not affected.

In our model, retirees face no income uncertainty. Their pension is set at 50 percent of permanent income in the last period of working life. That figure is between the 42 percent estimated in Munnell and Soto (2005) as the median replacement rate for newly retired workers, according to both the Health Retirement Survey and Social Security Administration data, and the 68 percent in Cocco, Gomes, and Maenhout (2005), calculated as a ratio of 
average income for retirees and average income in the last working year before retirement (PSID data).

To calibrate the moving shock, we use information on moving rates from the Current Population Survey, and follow Díaz and Luengo-Prado (2008), who calculate moving rates by age cohort. For example, in 2005, 10 percent of respondents aged 24 or older report having moved since the previous year. Moving rates are lower for homeowners and decrease with age. Among movers, roughly 53 percent report having moved for reasons other than housing choices (such as a new job, family reasons, and natural disasters). Because the moving shock in our model tries to capture these reasons for moving, we start with the yearly moving probabilities and multiply them by .53 . Also, because our model is calibrated so that one period is two years, we multiply the yearly probabilities by 1.8, to account for the fact that moving probabilities are not independent across years. Our simulation results are very similar if we just use a biennial 10 percent exogenous moving probability for all working-age households and no moving shock for retirees.

In our setup, there is no age limit on credit availability and in the event of death, houses are liquidated at the price in the previous period, to avoid most negative accidental bequests. A negative bequest is still possible for a homeowner who dies at a young age after a period of house-price depreciation. We assume the government takes the loss in this case.

\section{Market arrangements}

The minimum down payment is 20 percent, slightly below the 25 percent average down payment for 1963-2001 reported by the Federal Housing Finance Board. Gruber and Martin (2003), using CEX data, document that selling costs for housing can be up to 7 percent, while buying costs are around 2.5 percent. We set the selling cost equal to 6 percent, a typical realtor fee, and the buying cost to 2 percent, within the range of the estimates of those authors. The

interest rate on deposits, $r^{d}$, is set to 4 percent in annual terms (the average real rate for 19672005, as calculated in Díaz and Luengo-Prado [2009]), while the interest rate on mortgages is set to 4.5 percent.

\section{Taxes}

To calibrate the income tax rate, $\tau_{y}$, we use data on personal income and personal taxes from the National Income and Product Accounts (NIPA) of the Bureau of Economic Analysis, as well as information from TAXSIM, the NBER tax calculator. ${ }^{34}$ For the period 1989-2004, personal taxes represent 12.47 percent of personal income in NIPA. As in Prescott (2004), we multiply this number by 1.6 to reflect the fact that marginal income tax rates are usually higher than average rates. The 1.6 number is the mean ratio of marginal income tax rates to average tax rates, based on TAXSIM (see Feenberg and Coutts [1993]). The final number is 19.96 percent, which we approximate using $\tau_{y}=0.20$. We assume mortgage payments are fully deductible, $\tau_{m}=1$.

\footnotetext{
34 The TAXSIM data are available at http://www.nber.org/ taxsim.
} 


\section{House prices}

Housing prices follow the process $q_{t}=q_{t-1}\left(1+\mathrm{Q}_{t}\right)$, where $\mathrm{Q} \sim N\left(\mu_{\mathrm{Q}}, \sigma_{\mathrm{Q}}^{2}\right) \cdot \mu_{\mathrm{Q}}=0$ and $\sigma_{\mathrm{Q}}^{2}=.0132$ - as in $\mathrm{Li}$ and Yao (2007), and within the estimates of Goetzmann and Spiegel (2000). We assume $\varrho_{t}$ is serially uncorrelated, and uncorrelated with the income shocks. The housing maintenance cost rate, $\delta^{h}$, is set to 1.5 percent, as estimated in Harding, Rosenthal, and Sirmans (2007).

The rental price is proportional to house prices. In particular:

$$
r_{t}^{f}=\frac{q_{t}-E_{t}\left[\frac{1}{1+\left(1-\tau_{y}\right) r_{t+1}^{d}} q_{t+1}\left(1-\delta^{h}\right)\right]}{1-\tau_{y}}=q_{t} \frac{\left(1-\tau_{y}\right) r_{t+1}^{d}+\delta_{h}}{\left(1-\tau_{y}\right)\left(1+\left(1-\tau_{y}\right) r_{t+1}^{d}\right)},
$$

which can be interpreted as the user cost for a landlord who is not liquidity constrained, who is not subject to adjustment costs, and who pays income taxes on rental income. This calibration choice is consistent with the estimates in Sinai and Souleles (2005), who find that the house-price-to-rent ratio capitalizes expected future rents, as any other asset (see Díaz and Luengo-Prado [2009]). For our benchmark calibration, $r_{t} / q_{t}$ is roughly 5.7 percent annually.

\section{Alternative model specifications}

\section{Transitory and permanent displacement shocks}

Our benchmark calibration produces a coefficient for the displacement indicator that is about three times larger than in the data. To explore if we can better match the size of the displacement coefficient, we explore a specification in which we allow for permanent and transitory displacement shocks simultaneously. This change may also make our model more realistic, as the impact of displacement and disability can differ greatly across households.

As in our benchmark calibration, permanent shocks result in a 25 percent loss of income, but now occur with a 1 percent probability in annual terms. The probability that an individual will receive a transitory displacement shock is calibrated to be 5 percent, and involves a transitory income loss of 60 percent. This combination of shocks results in a mean for the displacement dummy of 0.116 and a standard deviation of 0.32 , matching PSID data in Table 1.

Table B-2 shows that this change brings down the estimated coefficient for the displacement indicator using simulated data from 17 percent (column [3] of Table 2) to 5 percent, in line with the estimated coefficient in PSID data. However, this change does not allow us to better match the size of the coefficients for the interaction terms of displacement shocks and houseprice growth. 


\section{Correlation between income shocks and house-price shocks}

To allow for a possible correlation between income shocks and house-price shocks, we modify the income process described in equation (6) by introducing a regional permanent shock, $g_{t}$, common to all residents of the region. Thus, $P_{t}=P_{t-1} g_{t} \gamma_{t} \varepsilon_{t} S_{t}$, where $\log g_{t} \sim$ $N\left(-\sigma_{g}{ }^{2} / 2, \sigma_{g}{ }^{2}\right)$. To calibrate $\sigma_{g}$, we use the evidence in Luengo-Prado and Sorensen (2008). We save on state variables by assuming that the regional income shock and the house-price shock are perfectly correlated. This case can be seen as the opposite extreme from our baseline calibration in terms of income/house-price correlation.

\section{A bequest motive}

We consider warm-glow altruism. The utility derived from bequeathing wealth, $X_{t}$, is:

$$
v\left(X_{t}\right)=b \frac{X_{t}\left(\alpha^{\alpha}\left[(1-\alpha) / r_{t}^{f_{t}}\right]^{1-\alpha}\right)^{1-\sigma}}{1-\sigma},
$$

where $b$ measures the strength of the bequest motive, and terminal wealth equals the value of the housing stock, after depreciation takes place and adjustment costs are paid, plus financial assets: $X_{t}=q_{t} h_{t}\left(1-\delta^{h}\right)(1-\chi)+d_{t}$.

The Cobb-Douglas utility assumption we use as our benchmark would result in the inheritor's expenditure on nondurable consumption, $c$, and housing service, $r_{t} f_{t}$, at a fixed proportion $\alpha /(1-\alpha)$. We consider bequests with and without correlation between income and house-price shocks. In this case, we have one additional calibration parameter, the strength of the bequest motive, so we add one additional target, the mean bequest-to-income ratio, set to 2.5 consistent with the evidence in Hendricks (2001).

\section{CES utility}

Table B-2 reports results using a different utility function under different specifications: no bequest or house-price/income correlation, and bequests with house-price/income correlation. In particular, we use the findings in Li, Liu, and Yao (2009), and consider a CES utility function with an intra-temporal elasticity of substitution between housing and nondurable consumption of 0.33 (i.e., housing and nondurables are complements).

In this case, the expenditure shares on housing and nondurables for renters are not independent of the relative price of the two goods, as in the Cobb-Douglas case. The parameter that controls the expenditure share on housing and nondurables, the discount rate, and the minimum house size are recalibrated to reproduce the same homeownership rate, wealth-to-income ratio, and ratio of house value to total wealth as in the case with a CobbDouglas utility function.

The estimated coefficients using our simulated data are not very sensitive to this change. For example, with no bequest or correlation between house prices and income shocks, the MPC 
for owners with CES utility is 0.11 versus 0.125 with Cobb-Douglas (the changes for other parameters are even lower). Most importantly, the house-price interaction terms are consistently significant for owners, indicating additional risk sharing, and not for renters. 
Table 1: Summary Statistics for Empirical Data

\begin{tabular}{lrrrr}
\hline Variable & Mean & SD & Min & Max \\
\hline$c_{i t}-\bar{c}_{t}$ & 0.000 & 0.443 & -1.722 & 1.706 \\
$y_{i t}-\bar{y}_{t}$ & -0.000 & 0.449 & -3.178 & 2.497 \\
$h_{m t}-\bar{h}_{t}$ & 0.000 & 0.141 & -0.636 & 0.579 \\
$\left(h_{m t}-\bar{h}_{t}\right) \times\left(y_{i t}-\bar{y}_{t}\right)$ & 0.003 & 0.061 & -0.599 & 0.826 \\
$D_{i t}$ & 0.116 & 0.320 & 0.000 & 1.000 \\
$\left(D_{i t}-\bar{D}_{t}\right) \times\left(h_{m t}-\bar{h}_{t}\right)$ & -0.001 & 0.048 & -0.459 & 0.488 \\
$L_{i t}$ & 0.019 & 0.277 & -1.000 & 1.000 \\
$\left(L_{i t}-\bar{L}_{t}\right) \times\left(h_{m t}-\bar{h}_{t}\right)$ & -0.000 & 0.039 & -0.579 & 0.564 \\
Owner & 0.698 & 0.459 & 0.000 & 1.000 \\
Age & 45.016 & 10.242 & 25.000 & 65.000 \\
\hline
\end{tabular}

Notes: Variable definitions as follows: $c_{i t}$ is the (4-year) log difference of consumption for individual $i$ in year $t, y_{i t}$ is the $\log$ difference of household income, and $\bar{y}_{t}$ is the mean log income difference in period $t . h_{m t}$ is the log difference in house prices in the metropolitan area where individual $i$ lives, while $\bar{h}_{t}$ is the mean log difference in house prices for all metros at time $t$. $D_{i t}$ is a dummy variable equal to 1 if individual $i$ receives a displacement shock in periods $t-3$, $t-2, t-1$, or $t$ and 0 otherwise; $L_{i t}$ is a variable equal to 1 if individual $i$ reports a condition limiting her ability to work at time $t$ and does not report having a limiting condition at time $t-4,-1$ is she reports a limiting condition in $t-4$ and not in $t$, and 0 otherwise. 
Table 2: Risk Sharing Regressions: The Effect of Housing Prices on Food Consumption. Full Sample

\begin{tabular}{|c|c|c|c|c|c|c|}
\hline & (1) & $(2)$ & $(3)$ & $(4)$ & $(5)$ & $(6)$ \\
\hline Income $\mathrm{G}$. & $\begin{array}{c}0.124^{* * *} \\
(15.15)\end{array}$ & $\begin{array}{c}0.122^{* * *} \\
(13.85)\end{array}$ & $\begin{array}{c}0.123^{* * *} \\
(14.59)\end{array}$ & & & \\
\hline House price $\mathrm{G}$. & $\begin{array}{c}0.120^{* * *} \\
(6.97)\end{array}$ & $\begin{array}{c}0.118^{* * *} \\
(6.60)\end{array}$ & $\begin{array}{c}0.120^{* * *} \\
(6.86)\end{array}$ & $\begin{array}{c}0.137^{* * *} \\
(7.36)\end{array}$ & $\begin{array}{c}0.140^{* * *} \\
(7.67)\end{array}$ & $\begin{array}{c}0.137^{* * *} \\
(7.28)\end{array}$ \\
\hline Inc. G. x House price G. & $\begin{array}{c}-0.127^{*} \\
(-1.95)\end{array}$ & & & & & \\
\hline Displaced & & $\begin{array}{c}-0.047^{* * *} \\
(-5.35)\end{array}$ & & $\begin{array}{c}-0.062^{* * *} \\
(-6.93)\end{array}$ & & $\begin{array}{c}-0.061^{* * *} \\
(-6.83)\end{array}$ \\
\hline Displaced x House price G. & & $\begin{array}{c}0.113^{*} \\
(1.93)\end{array}$ & & $\begin{array}{c}0.119^{* *} \\
(2.04)\end{array}$ & & $\begin{array}{c}0.115^{*} \\
(1.96)\end{array}$ \\
\hline Disabled & & & $\begin{array}{c}-0.036^{* * *} \\
(-3.74)\end{array}$ & & $\begin{array}{c}-0.047^{* * *} \\
(-4.81)\end{array}$ & $\begin{array}{c}-0.044^{* * *} \\
(-4.53)\end{array}$ \\
\hline Disability x House price G. & & & $\begin{array}{l}0.081 \\
(1.25)\end{array}$ & & $\begin{array}{l}0.092 \\
(1.37)\end{array}$ & $\begin{array}{l}0.080 \\
(1.16)\end{array}$ \\
\hline Fam. size G. & $\begin{array}{c}0.301^{* * *} \\
(23.21)\end{array}$ & $\begin{array}{c}0.303^{* * *} \\
(22.84)\end{array}$ & $\begin{array}{c}0.300^{* * *} \\
(23.18)\end{array}$ & $\begin{array}{c}0.306^{* * *} \\
(23.20)\end{array}$ & $\begin{array}{c}0.304^{* * *} \\
(23.54)\end{array}$ & $\begin{array}{c}0.306^{* * *} \\
(23.13)\end{array}$ \\
\hline Age & $\begin{array}{l}-0.002 \\
(-1.02)\end{array}$ & $\begin{array}{l}-0.003 \\
(-1.08)\end{array}$ & $\begin{array}{l}-0.003 \\
(-1.06)\end{array}$ & $\begin{array}{l}-0.002 \\
(-0.78)\end{array}$ & $\begin{array}{l}-0.001 \\
(-0.60)\end{array}$ & $\begin{array}{l}-0.002 \\
(-0.84)\end{array}$ \\
\hline Age sq./100 & $\begin{array}{l}-0.001 \\
(-0.27)\end{array}$ & $\begin{array}{l}-0.001 \\
(-0.22)\end{array}$ & $\begin{array}{l}-0.001 \\
(-0.22)\end{array}$ & $\begin{array}{l}-0.003 \\
(-0.92)\end{array}$ & $\begin{array}{l}-0.003 \\
(-1.09)\end{array}$ & $\begin{array}{l}-0.002 \\
(-0.85)\end{array}$ \\
\hline Adj. R sq. & 0.074 & 0.075 & 0.074 & 0.061 & 0.059 & 0.062 \\
\hline $\mathrm{F}$ & 191.2 & 152.8 & 167.8 & 145.0 & 148.6 & 122.4 \\
\hline $\mathrm{N}$ & 24,764 & 23,490 & 24,760 & 23,490 & 24,760 & 23,486 \\
\hline
\end{tabular}

Notes: In column (1), we run the regression: $c_{i t}-\bar{c}_{t}=\mu+\alpha\left(y_{i t}-\bar{y}_{t}\right)+\beta\left(h_{m t}-\bar{h}_{t}\right)+\gamma\left(y_{i t}-\bar{y}_{t}\right) \times\left(h_{m t}-\bar{h}_{t}\right)+$ $\left(X_{i t}-\bar{X}_{t}\right)^{\prime} \delta+\varepsilon_{i t}$, where $c_{i t}$ is the 4-year log difference of consumption for individual $i$ in year $t$, $y_{i t}$ is the 4-year $\log$ difference of household income, and $\bar{y}_{t}$ is the mean 4 -year log income difference in period $t$; $h_{m t}$ is the 4 -year log difference in house prices in the MSA where individual $i$ lives, while $\bar{h}_{t}$ is the mean 4-year log difference in house prices for the whole sample of MSAs, and $X_{i t}$ is a matrix of control variables. In column (2), we run the regression: $c_{i t}-\bar{c}_{t}=\mu+\alpha\left(y_{i t}-\bar{y}_{t}\right)+\beta\left(h_{m t}-\bar{h}_{t}\right)+\xi\left(D_{i t}-\bar{D}_{t}\right)+\zeta\left(D_{i t}-\bar{D}_{t}\right) \times\left(h_{m t}-\bar{h}_{t}\right)+\left(X_{i t}-\bar{X}_{t}\right)^{\prime} \delta+\varepsilon_{i t}$, where $D_{i t}$ is a dummy variable taking the value 1 if the head of household $i$ suffers displacement, 0 otherwise. In column (3), we run the same regression as in column (2) and use $L_{i t}$ instead of $D_{i t}$, where $L_{i t}$ captures the disability shock.

Our sample is restricted to households who resided in the same MSA and did not change family composition during that time span. Serial correlation in the regression errors is corrected using the Prais-Winsten transformation; robust standard errors in the regressions clustered by the MSA where the household lives between years $t$ and $t-4$. t-statistics in parentheses. $* * *$ significant at the $1 \%$ level, ${ }^{* *}$ significant at the $5 \%$ level, ${ }^{*}$ significant at the $10 \%$ level. 
TABle 3: Risk Sharing Regressions For Owners

\begin{tabular}{|c|c|c|c|c|c|c|}
\hline & $(1)$ & $(2)$ & $(3)$ & $(4)$ & $(5)$ & (6) \\
\hline Income G. & $\begin{array}{c}0.095^{* * *} \\
(10.79)\end{array}$ & $\begin{array}{c}0.095^{* * *} \\
(9.76)\end{array}$ & $\begin{array}{c}0.094^{* * *} \\
(10.46)\end{array}$ & & & \\
\hline House price G. & $\begin{array}{c}0.113^{* * *} \\
(5.28)\end{array}$ & $\begin{array}{c}0.117^{* * *} \\
(5.27)\end{array}$ & $\begin{array}{c}0.115^{* * *} \\
(5.36)\end{array}$ & $\begin{array}{c}0.131^{* * *} \\
(5.85)\end{array}$ & $\begin{array}{c}0.130^{* * *} \\
(5.94)\end{array}$ & $\begin{array}{c}0.130^{* * *} \\
(5.80)\end{array}$ \\
\hline Inc. G. x House price G. & $\begin{array}{c}-0.153^{* *} \\
(-2.56)\end{array}$ & & & & & \\
\hline Displaced & & $\begin{array}{c}-0.035^{* * *} \\
(-2.94)\end{array}$ & & $\begin{array}{c}-0.046^{\text {*** }} \\
(-3.80)\end{array}$ & & $\begin{array}{c}-0.044^{* * *} \\
(-3.70)\end{array}$ \\
\hline Displaced $x$ House price G. & & $\begin{array}{c}0.137^{*} \\
(1.81)\end{array}$ & & $\begin{array}{c}0.144^{*} \\
(1.87)\end{array}$ & & $\begin{array}{c}0.132^{*} \\
(1.72)\end{array}$ \\
\hline Disabled & & & $\begin{array}{c}-0.029^{* *} \\
(-2.51)\end{array}$ & & $\begin{array}{c}-0.037^{* * *} \\
(-3.29)\end{array}$ & $\begin{array}{c}-0.034^{* * *} \\
(-2.97)\end{array}$ \\
\hline Disability x House price G. & & & $\begin{array}{c}0.246^{* * *} \\
(3.30)\end{array}$ & & $\begin{array}{c}0.265^{* * *} \\
(3.49)\end{array}$ & $\begin{array}{c}0.252^{* * *} \\
(3.24)\end{array}$ \\
\hline Fam. size G. & $\begin{array}{c}0.331^{* * * *} \\
(22.91)\end{array}$ & $\begin{array}{c}0.333^{* * *} \\
(22.64)\end{array}$ & $\begin{array}{c}0.331^{* * * *} \\
(23.00)\end{array}$ & $\begin{array}{c}0.336^{* * *} \\
(22.78)\end{array}$ & $\begin{array}{c}0.335^{* * *} \\
(23.14)\end{array}$ & $\begin{array}{c}0.337^{* * * *} \\
(22.85)\end{array}$ \\
\hline Age & $\begin{array}{c}-0.007^{* *} \\
(-2.15)\end{array}$ & $\begin{array}{c}-0.006^{*} \\
(-1.88)\end{array}$ & $\begin{array}{c}-0.007^{* *} \\
(-2.22)\end{array}$ & $\begin{array}{l}-0.004 \\
(-1.24)\end{array}$ & $\begin{array}{l}-0.005 \\
(-1.51)\end{array}$ & $\begin{array}{l}-0.004 \\
(-1.27)\end{array}$ \\
\hline Age sq./100 & $\begin{array}{l}0.004 \\
(1.05)\end{array}$ & $\begin{array}{c}0.003 \\
(0.82)\end{array}$ & $\begin{array}{c}0.004 \\
(1.12)\end{array}$ & $\begin{array}{l}-0.000 \\
(-0.08)\end{array}$ & $\begin{array}{l}0.000 \\
(0.14)\end{array}$ & $\begin{array}{l}-0.000 \\
(-0.03)\end{array}$ \\
\hline Adj. R sq. & 0.090 & 0.090 & 0.090 & 0.080 & 0.080 & 0.081 \\
\hline $\mathrm{F}$ & 177.8 & 135.6 & 177.6 & 150.3 & 192.3 & 131.1 \\
\hline $\mathrm{N}$ & 17,277 & 16,288 & 17,273 & 16,288 & 17,273 & 16,284 \\
\hline
\end{tabular}

Notes: See notes to Table 2. Sample is restricted to households who continuously owned a house between years $t$ and $t-4$, resided in the same MSA and did not change family composition during that time span. Serial correlation in the regression errors is corrected using the Prais-Winsten transformation; robust standard errors in the regressions clustered by the MSA where the household lives between years $t$ and $t-4$. t-statistics in parentheses. *** significant at the $1 \%$ level, ${ }^{* *}$ significant at the $5 \%$ level, * significant at the $10 \%$ level. 
TABle 4: Risk Sharing Regressions for Renters

\begin{tabular}{|c|c|c|c|c|c|c|}
\hline & $(1)$ & $(2)$ & $(3)$ & $(4)$ & $(5)$ & $(6)$ \\
\hline Income G. & $\begin{array}{c}0.176^{* * *} \\
(11.56)\end{array}$ & $\begin{array}{c}0.167^{* * *} \\
(10.51)\end{array}$ & $\begin{array}{c}0.174^{* * *} \\
(11.20)\end{array}$ & & & \\
\hline House price G. & $\begin{array}{c}0.130^{* * *} \\
(3.06)\end{array}$ & $\begin{array}{c}0.120^{* * *} \\
(2.93)\end{array}$ & $\begin{array}{c}0.125^{* * *} \\
(3.01)\end{array}$ & $\begin{array}{c}0.149^{* * *} \\
(3.42)\end{array}$ & $\begin{array}{c}0.159^{* * *} \\
(3.57)\end{array}$ & $\begin{array}{c}0.149^{* * *} \\
(3.49)\end{array}$ \\
\hline Inc. G. $x$ House price G. & $\begin{array}{l}-0.098 \\
(-0.87)\end{array}$ & & & & & \\
\hline Displaced & & $\begin{array}{c}-0.057^{* * *} \\
(-3.23)\end{array}$ & & $\begin{array}{c}-0.082^{* * *} \\
(-4.62)\end{array}$ & & $\begin{array}{c}-0.081^{* * *} \\
(-4.61)\end{array}$ \\
\hline Displaced x House price G. & & $\begin{array}{c}0.076 \\
(0.70)\end{array}$ & & $\begin{array}{l}0.079 \\
(0.73)\end{array}$ & & $\begin{array}{l}0.075 \\
(0.69)\end{array}$ \\
\hline Disabled & & & $\begin{array}{c}-0.043^{* *} \\
(-2.07)\end{array}$ & & $\begin{array}{c}-0.058^{* *} \\
(-2.57)\end{array}$ & $\begin{array}{c}-0.055^{* *} \\
(-2.47)\end{array}$ \\
\hline Disability x House price G. & & & $\begin{array}{l}-0.163 \\
(-1.05)\end{array}$ & & $\begin{array}{l}-0.180 \\
(-1.09)\end{array}$ & $\begin{array}{l}-0.184 \\
(-1.11)\end{array}$ \\
\hline Fam. size G. & $\begin{array}{c}0.252^{* * *} \\
(14.26)\end{array}$ & $\begin{array}{c}0.257^{* * *} \\
(14.13)\end{array}$ & $\begin{array}{c}0.252^{* * *} \\
(14.17)\end{array}$ & $\begin{array}{c}0.262^{* * *} \\
(14.71)\end{array}$ & $\begin{array}{c}0.255^{* * *} \\
(14.54)\end{array}$ & $\begin{array}{c}0.261^{* * *} \\
(14.49)\end{array}$ \\
\hline Age & $\begin{array}{l}0.002 \\
(0.48)\end{array}$ & $\begin{array}{c}0.002 \\
(0.38)\end{array}$ & $\begin{array}{l}0.002 \\
(0.48)\end{array}$ & $\begin{array}{l}-0.000 \\
(-0.09)\end{array}$ & $\begin{array}{c}0.000 \\
(0.12)\end{array}$ & $\begin{array}{l}-0.001 \\
(-0.12)\end{array}$ \\
\hline Age sq./100 & $\begin{array}{l}-0.005 \\
(-1.13)\end{array}$ & $\begin{array}{l}-0.005 \\
(-1.12)\end{array}$ & $\begin{array}{l}-0.005 \\
(-1.12)\end{array}$ & $\begin{array}{l}-0.004 \\
(-0.97)\end{array}$ & $\begin{array}{l}-0.005 \\
(-1.08)\end{array}$ & $\begin{array}{l}-0.004 \\
(-0.93)\end{array}$ \\
\hline Adj. R sq. & 0.059 & 0.060 & 0.059 & 0.039 & 0.036 & 0.040 \\
\hline $\mathrm{F}$ & 95.9 & 84.3 & 84.7 & 46.9 & 41.6 & 36.9 \\
\hline $\mathrm{N}$ & 7,487 & 7,202 & 7,487 & 7,202 & 7,487 & 7,202 \\
\hline
\end{tabular}

Notes: See notes to Table 2. Sample is restricted to households who continuously rented a house between years $t$ and $t-4$, resided in the same MSA and did not change family composition during that time span. Serial correlation in the regression errors is corrected using the Prais-Winsten transformation; robust standard errors in the regressions clustered by the MSA where the household lives between years $t$ and $t-4$. t-statistics in parentheses. *** significant at the $1 \%$ level, ${ }^{* *}$ significant at the $5 \%$ level, * significant at the $10 \%$ level. 
Table 5: Risk Sharing Regressions. Non-overlapping Growth Rates

\begin{tabular}{|c|c|c|c|c|c|c|c|c|}
\hline & \multicolumn{4}{|c|}{ Owners } & \multicolumn{4}{|c|}{ Renters } \\
\hline & $(1)$ & $(2)$ & $(3)$ & $(4)$ & $(5)$ & $(6)$ & $(7)$ & $(8)$ \\
\hline Income G. & $\begin{array}{c}0.088^{* * * *} \\
(7.48)\end{array}$ & $\begin{array}{c}0.085^{* * *} \\
(7.06)\end{array}$ & $\begin{array}{c}0.086^{* * *} \\
(7.33)\end{array}$ & & $\begin{array}{c}0.172^{* * * *} \\
(8.09)\end{array}$ & $\begin{array}{c}0.168^{* * *} \\
(7.90)\end{array}$ & $\begin{array}{c}0.170^{* * *} \\
(8.04)\end{array}$ & \\
\hline House price G. & $\begin{array}{c}0.108^{* * *} \\
(2.91)\end{array}$ & $\begin{array}{c}0.117^{* * *} \\
(3.12)\end{array}$ & $\begin{array}{c}0.120^{* * *} \\
(3.25)\end{array}$ & $\begin{array}{c}0.134^{* * *} \\
(3.61)\end{array}$ & $\begin{array}{c}0.121 \\
(1.12)\end{array}$ & $\begin{array}{c}0.117 \\
(1.10)\end{array}$ & $\begin{array}{c}0.121 \\
(1.13)\end{array}$ & $\begin{array}{l}0.147 \\
(1.37)\end{array}$ \\
\hline Inc. G. x House price G. & $\begin{array}{c}-0.259 * * * \\
(-2.70)\end{array}$ & & & & $\begin{array}{l}-0.056 \\
(-0.32)\end{array}$ & & & \\
\hline Displaced & & $\begin{array}{c}-0.061^{* * *} \\
(-3.54)\end{array}$ & & $\begin{array}{c}-0.069^{* * *} \\
(-3.98)\end{array}$ & & $\begin{array}{c}-0.052^{*} \\
(-1.85)\end{array}$ & & $\begin{array}{c}-0.077^{* * *} \\
(-2.62)\end{array}$ \\
\hline Displaced $x$ House price G. & & $\begin{array}{c}0.273^{* *} \\
(2.27)\end{array}$ & & $\begin{array}{c}0.287^{* *} \\
(2.40)\end{array}$ & & $\begin{array}{l}-0.068 \\
(-0.36)\end{array}$ & & $\begin{array}{l}-0.083 \\
(-0.42)\end{array}$ \\
\hline Disabled & & & $\begin{array}{c}-0.052^{* *} \\
(-2.41)\end{array}$ & $\begin{array}{c}-0.058^{* * *} \\
(-2.69)\end{array}$ & & & $\begin{array}{l}-0.057 \\
(-1.62)\end{array}$ & $\begin{array}{c}-0.077^{* *} \\
(-2.15)\end{array}$ \\
\hline Disability x House price G. & & & $\begin{array}{c}0.303^{*} \\
(1.78)\end{array}$ & $\begin{array}{c}0.315^{*} \\
(1.88)\end{array}$ & & & $\begin{array}{c}0.284 \\
(1.03)\end{array}$ & $\begin{array}{l}0.277 \\
(0.98)\end{array}$ \\
\hline Fam. size G. & $\begin{array}{c}0.362^{* * *} \\
(16.46)\end{array}$ & $\begin{array}{c}0.360^{* * * *} \\
(16.44)\end{array}$ & $\begin{array}{c}0.361^{* * *} \\
(16.44)\end{array}$ & $\begin{array}{c}0.363^{* * *} \\
(17.12)\end{array}$ & $\begin{array}{c}0.290^{* * * *} \\
(8.84)\end{array}$ & $\begin{array}{c}0.290^{* * *} \\
(8.85)\end{array}$ & $\begin{array}{c}0.290^{* * *} \\
(8.96)\end{array}$ & $\begin{array}{c}0.301^{* * *} \\
(9.68)\end{array}$ \\
\hline Age & $\begin{array}{l}-0.002 \\
(-0.38)\end{array}$ & $\begin{array}{l}-0.002 \\
(-0.46)\end{array}$ & $\begin{array}{l}-0.003 \\
(-0.50)\end{array}$ & $\begin{array}{l}-0.001 \\
(-0.13)\end{array}$ & $\begin{array}{c}0.010 \\
(1.23)\end{array}$ & $\begin{array}{c}0.010 \\
(1.23)\end{array}$ & $\begin{array}{c}0.010 \\
(1.20)\end{array}$ & $\begin{array}{l}0.008 \\
(0.92)\end{array}$ \\
\hline Age sq./100 & $\begin{array}{l}-0.001 \\
(-0.29)\end{array}$ & $\begin{array}{l}-0.001 \\
(-0.24)\end{array}$ & $\begin{array}{l}-0.001 \\
(-0.14)\end{array}$ & $\begin{array}{l}-0.004 \\
(-0.69)\end{array}$ & $\begin{array}{c}-0.015^{*} \\
(-1.67)\end{array}$ & $\begin{array}{c}-0.015^{*} \\
(-1.70)\end{array}$ & $\begin{array}{l}-0.014 \\
(-1.63)\end{array}$ & $\begin{array}{l}-0.014 \\
(-1.52)\end{array}$ \\
\hline Adj. R sq. & 0.103 & 0.104 & 0.104 & 0.098 & 0.076 & 0.077 & 0.077 & 0.055 \\
\hline $\mathrm{F}$ & 92.4 & 83.8 & 97.0 & 89.1 & 37.8 & 36.8 & 33.6 & 18.7 \\
\hline $\mathrm{N}$ & 6,143 & 6,143 & 6,142 & 6,142 & 2,495 & 2,495 & 2,495 & 2,495 \\
\hline
\end{tabular}

Notes: See notes to Table 2. We use 4-year log differences from 1980, 1984, 1990, 1994, 1999 and 2003 only (food expenditures were not collected in 1988 and 1989 in the PSID). OLS regressions; robust standard errors in the regressions clustered by the MSA where the household lives between years $t$ and $t-4$. t-statistics in parentheses. ${ }^{* * *}$ significant at the $1 \%$ level, ${ }^{* *}$ significant at the $5 \%$ level, * significant at the $10 \%$ level. 
Table 6: Risk Sharing Regressions. House Price Residuals

\begin{tabular}{|c|c|c|c|c|c|c|c|c|}
\hline & \multicolumn{4}{|c|}{ Owners } & \multicolumn{4}{|c|}{ Renters } \\
\hline & (1) & $(2)$ & (3) & (4) & $(5)$ & $(6)$ & (7) & (8) \\
\hline Income $\mathrm{G}$. & $\begin{array}{c}0.096^{* * *} \\
(10.67)\end{array}$ & $\begin{array}{c}0.096^{* * *} \\
(9.78)\end{array}$ & $\begin{array}{c}0.094^{* * *} \\
(10.47)\end{array}$ & & $\begin{array}{c}0.177^{* * *} \\
(11.57)\end{array}$ & $\begin{array}{c}0.168^{* * *} \\
(10.49)\end{array}$ & $\begin{array}{c}0.175^{* * *} \\
(11.19)\end{array}$ & \\
\hline House price G. & $\begin{array}{c}0.101^{* * *} \\
(4.54)\end{array}$ & $\begin{array}{c}0.104^{* * *} \\
(4.52)\end{array}$ & $\begin{array}{c}0.102^{* * *} \\
(4.58)\end{array}$ & $\begin{array}{c}0.114^{* * *} \\
(4.88)\end{array}$ & $\begin{array}{c}0.100^{* *} \\
(2.41)\end{array}$ & $\begin{array}{c}0.090^{* *} \\
(2.20)\end{array}$ & $\begin{array}{c}0.095^{* *} \\
(2.28)\end{array}$ & $\begin{array}{c}0.115^{* * *} \\
(2.67)\end{array}$ \\
\hline Inc. G. $x$ House price G. & $\begin{array}{c}-0.131^{* *} \\
(-2.26)\end{array}$ & & & & $\begin{array}{l}-0.104 \\
(-0.92)\end{array}$ & & & \\
\hline Displaced & & $\begin{array}{c}-0.036^{* * *} \\
(-3.02)\end{array}$ & & $\begin{array}{c}-0.046^{* * *} \\
(-3.77)\end{array}$ & & $\begin{array}{c}-0.057^{* * *} \\
(-3.27)\end{array}$ & & $\begin{array}{c}-0.082^{* * *} \\
(-4.69)\end{array}$ \\
\hline Displaced x House price G. & & $\begin{array}{c}0.140^{*} \\
(1.75)\end{array}$ & & $\begin{array}{c}0.134^{*} \\
(1.65)\end{array}$ & & $\begin{array}{l}0.074 \\
(0.55)\end{array}$ & & $\begin{array}{l}0.063 \\
(0.47)\end{array}$ \\
\hline Disabled & & & $\begin{array}{c}-0.029^{* *} \\
(-2.55)\end{array}$ & $\begin{array}{c}-0.034^{* * *} \\
(-3.00)\end{array}$ & & & $\begin{array}{c}-0.043^{* *} \\
(-2.06)\end{array}$ & $\begin{array}{c}-0.055^{* *} \\
(-2.45)\end{array}$ \\
\hline Disability x House price G. & & & $\begin{array}{c}0.254^{* * *} \\
(3.04)\end{array}$ & $\begin{array}{c}0.261^{* * *} \\
(3.05)\end{array}$ & & & $\begin{array}{l}-0.141 \\
(-0.85)\end{array}$ & $\begin{array}{l}-0.162 \\
(-0.91)\end{array}$ \\
\hline Fam. size G. & $\begin{array}{c}0.331^{* * *} \\
(22.88)\end{array}$ & $\begin{array}{c}0.334^{* * *} \\
(22.62)\end{array}$ & $\begin{array}{c}0.332^{* * * *} \\
(22.96)\end{array}$ & $\begin{array}{c}0.337^{* * *} \\
(22.79)\end{array}$ & $\begin{array}{c}0.252^{* * *} \\
(14.15)\end{array}$ & $\begin{array}{c}0.256^{* * *} \\
(14.02)\end{array}$ & $\begin{array}{c}0.251^{* * *} * \\
(14.04)\end{array}$ & $\begin{array}{c}0.260^{* * *} * \\
(14.33)\end{array}$ \\
\hline Age & $\begin{array}{c}-0.007^{* *} \\
(-2.16)\end{array}$ & $\begin{array}{c}-0.006^{*} \\
(-1.86)\end{array}$ & $\begin{array}{c}-0.007^{* *} \\
(-2.21)\end{array}$ & $\begin{array}{l}-0.004 \\
(-1.25)\end{array}$ & $\begin{array}{l}0.002 \\
(0.48)\end{array}$ & $\begin{array}{l}0.002 \\
(0.37)\end{array}$ & $\begin{array}{l}0.002 \\
(0.47)\end{array}$ & $\begin{array}{l}-0.001 \\
(-0.14)\end{array}$ \\
\hline Age sq./100 & $\begin{array}{l}0.004 \\
(1.05)\end{array}$ & $\begin{array}{l}0.003 \\
(0.81)\end{array}$ & $\begin{array}{c}0.004 \\
(1.11)\end{array}$ & $\begin{array}{l}-0.000 \\
(-0.05)\end{array}$ & $\begin{array}{l}-0.005 \\
(-1.11)\end{array}$ & $\begin{array}{l}-0.005 \\
(-1.10)\end{array}$ & $\begin{array}{l}-0.005 \\
(-1.10)\end{array}$ & $\begin{array}{l}-0.004 \\
(-0.91)\end{array}$ \\
\hline Adj. R sq. & 0.089 & 0.090 & 0.090 & 0.080 & 0.058 & 0.060 & 0.059 & 0.039 \\
\hline $\mathrm{F}$ & 174.0 & 135.2 & 173.7 & 130.4 & 95.5 & 83.6 & 82.9 & 31.1 \\
\hline $\mathrm{N}$ & 17,277 & 16,288 & 17,273 & 16,284 & 7,487 & 7,202 & 7,487 & 7,202 \\
\hline
\end{tabular}

Notes: See notes to Table 2. The only difference is that instead of house-price appreciation by MSA, we use the residuals from a regression of MSA house-price appreciation on MSA income growth as our measure of house-price growth. 
Table 7: First-Stage Regression for Income Growth

\begin{tabular}{lcc}
\hline \hline & Owners & Renters \\
\hline & & \\
Income G. (coh/edu./year group) & $0.222^{* * *}$ & $0.258^{* * *}$ \\
& $(4.66)$ & $(2.95)$ \\
MSA Income G. & $0.551^{* * *}$ & $0.575^{* * *}$ \\
& $(7.07)$ & $(4.13)$ \\
House price G. & $0.089^{* * *}$ & $0.117^{* * *}$ \\
& $(3.52)$ & $(2.76)$ \\
Displaced & $-0.105^{* * *}$ & $-0.152^{* * *}$ \\
& $(-9.21)$ & $(-9.94)$ \\
Displaced x House price G. & 0.061 & -0.075 \\
& $(0.77)$ & $(-0.69)$ \\
Disabled & $-0.114^{* * *}$ & $-0.092^{* * *}$ \\
& $(-9.17)$ & $(-5.19)$ \\
Disability x House price G. & $0.189^{* *}$ & -0.070 \\
& $(1.99)$ & $(-0.52)$ \\
Fam. size G. & $0.034^{* * *}$ & $0.031^{*}$ \\
Age & $(2.75)$ & $(1.84)$ \\
& $0.026^{* * *}$ & $-0.010^{* *}$ \\
Age sq./100 & $(7.57)$ & $(-2.06)$ \\
Adj. R sq. & $-0.034^{* * *}$ & 0.004 \\
F (instruments) & $(-9.44)$ & $(0.76)$ \\
N & 0.058 & 0.050 \\
\hline
\end{tabular}

Notes: The instruments for income are the mean of the 4-year log difference of income for the respondent's cohort/education/year group in period $t$ (excluding the respondent) and the 4-year log MSA income difference. t-statistics in parentheses. *** significant at the $1 \%$ level, ${ }^{* *}$ significant at the $5 \%$ level, ${ }^{*}$ significant at the $10 \%$ level. 
Table 8: IV Risk Sharing Regressions

\begin{tabular}{|c|c|c|c|c|c|c|}
\hline & \multicolumn{3}{|c|}{ Owners } & \multicolumn{3}{|c|}{ Renters } \\
\hline & (1) & $(2)$ & (3) & (4) & $(5)$ & $(6)$ \\
\hline Income $\mathrm{G}$. & $\begin{array}{c}0.469^{* * *} \\
(3.27)\end{array}$ & $\begin{array}{c}0.469^{* * *} \\
(3.09)\end{array}$ & $\begin{array}{c}0.457^{* * *} \\
(3.01)\end{array}$ & $\begin{array}{c}0.563^{* *} \\
(2.29)\end{array}$ & $\begin{array}{l}0.558^{*} \\
(1.82)\end{array}$ & $\begin{array}{l}0.628^{*} \\
(1.92)\end{array}$ \\
\hline House price G. & $\begin{array}{c}0.056^{*} \\
(1.79)\end{array}$ & $\begin{array}{c}0.066^{* *} \\
(1.99)\end{array}$ & $\begin{array}{c}0.071^{* *} \\
(2.22)\end{array}$ & $\begin{array}{c}0.031 \\
(0.61)\end{array}$ & $\begin{array}{l}0.049 \\
(0.86)\end{array}$ & $\begin{array}{l}0.043 \\
(0.73)\end{array}$ \\
\hline Displaced & $\begin{array}{l}0.008 \\
(0.36)\end{array}$ & $\begin{array}{c}0.008 \\
(0.35)\end{array}$ & $\begin{array}{l}0.006 \\
(0.29)\end{array}$ & $\begin{array}{l}0.002 \\
(0.05)\end{array}$ & $\begin{array}{l}0.001 \\
(0.02)\end{array}$ & $\begin{array}{l}0.008 \\
(0.16)\end{array}$ \\
\hline Displaced x House price G. & $\begin{array}{l}0.121 \\
(1.47)\end{array}$ & $\begin{array}{l}0.121 \\
(1.42)\end{array}$ & $\begin{array}{l}0.122 \\
(1.44)\end{array}$ & $\begin{array}{l}0.068 \\
(0.45)\end{array}$ & $\begin{array}{l}0.061 \\
(0.40)\end{array}$ & $\begin{array}{l}0.067 \\
(0.42)\end{array}$ \\
\hline Disabled & $\begin{array}{l}0.012 \\
(0.68)\end{array}$ & $\begin{array}{c}0.012 \\
(0.66)\end{array}$ & $\begin{array}{l}0.012 \\
(0.62)\end{array}$ & $\begin{array}{l}-0.008 \\
(-0.23)\end{array}$ & $\begin{array}{l}-0.008 \\
(-0.22)\end{array}$ & $\begin{array}{l}-0.001 \\
(-0.01)\end{array}$ \\
\hline Disability x House price G. & $\begin{array}{c}0.194^{* *} \\
(1.99)\end{array}$ & $\begin{array}{c}0.199^{* *} \\
(2.02)\end{array}$ & $\begin{array}{c}0.202^{* *} \\
(2.05)\end{array}$ & $\begin{array}{l}-0.145 \\
(-0.91)\end{array}$ & $\begin{array}{l}-0.138 \\
(-0.86)\end{array}$ & $\begin{array}{l}-0.122 \\
(-0.78)\end{array}$ \\
\hline Fam. size G. & $\begin{array}{c}0.325^{* * *} \\
(18.50)\end{array}$ & $\begin{array}{c}0.326^{* * *} \\
(18.61)\end{array}$ & $\begin{array}{c}0.326^{* * *} \\
(18.79)\end{array}$ & $\begin{array}{c}0.247^{* * *} \\
(10.44)\end{array}$ & $\begin{array}{c}0.246^{* * *} \\
(9.98)\end{array}$ & $\begin{array}{c}0.243^{* * *} \\
\quad(9.29)\end{array}$ \\
\hline Age & $\begin{array}{c}-0.016^{* * *} \\
(-2.60)\end{array}$ & $\begin{array}{c}-0.016^{* *} \\
(-2.54)\end{array}$ & $\begin{array}{c}-0.015^{* *} \\
(-2.53)\end{array}$ & $\begin{array}{l}0.005 \\
(1.05)\end{array}$ & $\begin{array}{l}0.005 \\
(1.00)\end{array}$ & $\begin{array}{c}0.007 \\
(1.22)\end{array}$ \\
\hline Age sq./100 & $\begin{array}{c}0.016^{* *} \\
(2.21)\end{array}$ & $\begin{array}{c}0.016^{* *} \\
(2.15)\end{array}$ & $\begin{array}{c}0.016^{* *} \\
(2.12)\end{array}$ & $\begin{array}{l}-0.006 \\
(-1.13)\end{array}$ & $\begin{array}{l}-0.006 \\
(-1.13)\end{array}$ & $\begin{array}{l}-0.007 \\
(-1.28)\end{array}$ \\
\hline State effects & $\mathrm{N}$ & $\mathrm{Y}$ & $\mathrm{Y}$ & $\mathrm{N}$ & $\mathrm{Y}$ & $\mathrm{Y}$ \\
\hline Year effects & $\mathrm{N}$ & $\mathrm{N}$ & $\mathrm{Y}$ & $\mathrm{N}$ & $\mathrm{N}$ & $\mathrm{Y}$ \\
\hline $\mathrm{N}$ & 16,284 & 16,281 & 16,281 & 7,202 & 7,200 & 7,200 \\
\hline
\end{tabular}

Notes: See notes to Table 2. Regressions use the residual measure of house-price appreciation as in Table 6. t-statistics in parentheses. *** significant at the $1 \%$ level, ** significant at the $5 \%$ level, $*$ significant at the $10 \%$ level. 
Table 9: Risk Sharing Regressions. Young vs. Old

\begin{tabular}{|c|c|c|c|c|c|c|c|c|}
\hline & \multicolumn{4}{|c|}{ YOUNG } & \multicolumn{4}{|c|}{ OLD } \\
\hline & \multicolumn{2}{|c|}{ Owner } & \multicolumn{2}{|c|}{ Renter } & \multicolumn{2}{|c|}{ Owner } & \multicolumn{2}{|c|}{ Renter } \\
\hline & $(1)$ & $(2)$ & $(3)$ & $(4)$ & $(5)$ & $(6)$ & $(7)$ & $(8)$ \\
\hline Income G. & $\begin{array}{c}0.134^{* * *} \\
(6.38)\end{array}$ & $\begin{array}{c}0.126^{* * *} \\
(6.26)\end{array}$ & $\begin{array}{c}0.175^{* * *} \\
(8.88)\end{array}$ & $\begin{array}{c}0.183^{* * *} \\
(9.36)\end{array}$ & $\begin{array}{c}0.092^{* * *} \\
(7.60)\end{array}$ & $\begin{array}{c}0.092^{* * *} \\
(7.69)\end{array}$ & $\begin{array}{c}0.173^{* * *} \\
(6.29)\end{array}$ & $\begin{array}{c}0.181^{* * *} \\
(6.61)\end{array}$ \\
\hline House price G. & $\begin{array}{c}0.099 * * \\
(2.29)\end{array}$ & $\begin{array}{c}0.098^{* *} \\
(2.33)\end{array}$ & $\begin{array}{c}0.120^{* *} \\
(2.06)\end{array}$ & $\begin{array}{c}0.114^{*} \\
(1.95)\end{array}$ & $\begin{array}{c}0.126^{* * *} \\
(3.31)\end{array}$ & $\begin{array}{c}0.117^{* * *} \\
(3.03)\end{array}$ & $\begin{array}{r}0.078 \\
(0.73)\end{array}$ & $\begin{array}{l}0.060 \\
(0.59)\end{array}$ \\
\hline Displaced & $\begin{array}{l}-0.011 \\
(-0.53)\end{array}$ & & $\begin{array}{c}-0.042^{*} \\
(-1.81)\end{array}$ & & $\begin{array}{c}-0.059^{* * *} \\
(-3.58)\end{array}$ & & $\begin{array}{c}-0.155^{* * *} \\
(-3.78)\end{array}$ & \\
\hline Displaced x House price G. & $\begin{array}{l}-0.035 \\
(-0.31)\end{array}$ & & $\begin{array}{l}-0.065 \\
(-0.46)\end{array}$ & & $\begin{array}{c}0.252 \\
(1.61)\end{array}$ & & $\begin{array}{l}0.286 \\
(0.92)\end{array}$ & \\
\hline Disabled & & $\begin{array}{l}-0.040 \\
(-1.38)\end{array}$ & & $\begin{array}{l}-0.001 \\
(-0.03)\end{array}$ & & $\begin{array}{c}-0.038^{* *} \\
(-2.37)\end{array}$ & & $\begin{array}{c}-0.075^{* *} \\
(-2.41)\end{array}$ \\
\hline Disability x House price G. & & $\begin{array}{l}0.123 \\
(0.57)\end{array}$ & & $\begin{array}{c}-0.527^{*} \\
(-1.74)\end{array}$ & & $\begin{array}{c}0.272^{* * * *} \\
(2.71)\end{array}$ & & $\begin{array}{l}-0.147 \\
(-0.65)\end{array}$ \\
\hline Fam. size G. & $\begin{array}{c}0.297^{* * *} \\
(11.92)\end{array}$ & $\begin{array}{c}0.291^{* * *} \\
(12.07)\end{array}$ & $\begin{array}{c}0.267^{* * *} \\
(9.63)\end{array}$ & $\begin{array}{c}0.256^{* * *} \\
(9.60)\end{array}$ & $\begin{array}{c}0.324^{* * *} \\
(14.10)\end{array}$ & $\begin{array}{c}0.324^{* * *} \\
(14.50)\end{array}$ & $\begin{array}{c}0.294^{* * *} \\
(7.77)\end{array}$ & $\begin{array}{c}0.290^{* * * *} \\
(7.75)\end{array}$ \\
\hline Age & $\begin{array}{c}0.074^{* * * *} \\
(3.08)\end{array}$ & $\begin{array}{c}0.065^{* * * *} \\
(2.88)\end{array}$ & $\begin{array}{l}-0.041 \\
(-1.30)\end{array}$ & $\begin{array}{l}-0.039 \\
(-1.27)\end{array}$ & $\begin{array}{c}-0.055^{* * *} \\
(-3.43)\end{array}$ & $\begin{array}{c}-0.049^{* * *} \\
(-3.16)\end{array}$ & $\begin{array}{l}-0.038 \\
(-0.83)\end{array}$ & $\begin{array}{l}-0.042 \\
(-0.95)\end{array}$ \\
\hline Age sq./100 & $\begin{array}{c}-0.109^{* * *} \\
(-3.14)\end{array}$ & $\begin{array}{c}-0.096^{* * *} \\
(-2.95)\end{array}$ & $\begin{array}{l}0.063 \\
(1.33)\end{array}$ & $\begin{array}{c}0.061 \\
(1.32)\end{array}$ & $\begin{array}{c}0.047^{* * *} \\
(3.28)\end{array}$ & $\begin{array}{c}0.042^{* * * *} \\
(3.06)\end{array}$ & $\begin{array}{c}0.032 \\
(0.81)\end{array}$ & $\begin{array}{l}0.038 \\
(0.98)\end{array}$ \\
\hline Adj. R sq. & 0.050 & 0.047 & 0.045 & 0.045 & 0.073 & 0.074 & 0.063 & 0.060 \\
\hline $\mathrm{F}$ & 59.4 & 62.7 & 44.2 & 48.8 & 73.6 & 94.1 & 26.4 & 23.5 \\
\hline $\mathrm{N}$ & 5,142 & 5,408 & 3,883 & 4,027 & 5,739 & 6,039 & 1,689 & 1,729 \\
\hline
\end{tabular}

Notes: See notes to Table 2. Young is up to 40 years old; old is above 50. Regressions use the residual measure of houseprice appreciation as in Table 6. t-statistics in parentheses. $* * *$ significant at the $1 \%$ level, $* *$ significant at the $5 \%$ level, $*$ significant at the $10 \%$ level. 
Table 10: Risk Sharing Regressions. Food Consumption at Home

\begin{tabular}{|c|c|c|c|c|c|c|c|c|}
\hline & \multicolumn{4}{|c|}{ Owners } & \multicolumn{4}{|c|}{ Renters } \\
\hline & $(1)$ & $(2)$ & $(3)$ & $(4)$ & $(5)$ & $(6)$ & $(7)$ & $(8)$ \\
\hline Income $\mathrm{G}$. & $\begin{array}{c}0.070^{* * *} \\
(6.75)\end{array}$ & $\begin{array}{c}0.068^{* * *} \\
(6.08)\end{array}$ & $\begin{array}{c}0.069^{* * *} \\
(6.66)\end{array}$ & & $\begin{array}{c}0.150^{* * *} \\
(9.17)\end{array}$ & $\begin{array}{c}0.145^{* * *} \\
(8.55)\end{array}$ & $\begin{array}{c}0.148^{* * *} \\
(8.87)\end{array}$ & \\
\hline House price G. & $\begin{array}{c}0.123^{* * *} \\
(5.31)\end{array}$ & $\begin{array}{c}0.128^{* * *} \\
(5.26)\end{array}$ & $\begin{array}{c}0.124^{* * * *} \\
(5.24)\end{array}$ & $\begin{array}{c}0.135^{* * *} \\
(5.48)\end{array}$ & $\begin{array}{c}0.153^{* * *} \\
(3.57)\end{array}$ & $\begin{array}{c}0.141^{* * *} \\
(3.31)\end{array}$ & $\begin{array}{c}0.147^{* * * *} \\
(3.44)\end{array}$ & $\begin{array}{c}0.162^{* * *} \\
(3.59)\end{array}$ \\
\hline Inc. G. $x$ House price G. & $\begin{array}{l}-0.100 \\
(-1.52)\end{array}$ & & & & $\begin{array}{l}-0.118 \\
(-0.92)\end{array}$ & & & \\
\hline Displaced & & $\begin{array}{c}-0.035^{* * *} \\
(-3.14)\end{array}$ & & $\begin{array}{c}-0.042^{* * * *} \\
(-3.63)\end{array}$ & & $\begin{array}{l}-0.027 \\
(-1.53)\end{array}$ & & $\begin{array}{c}-0.049 * * * \\
(-2.82)\end{array}$ \\
\hline Displaced x House price G. & & $\begin{array}{c}0.165^{*} \\
(1.89)\end{array}$ & & $\begin{array}{c}0.154^{*} \\
(1.73)\end{array}$ & & $\begin{array}{l}0.169 \\
(1.31)\end{array}$ & & $\begin{array}{l}0.160 \\
(1.22)\end{array}$ \\
\hline Disabled & & & $\begin{array}{c}-0.025^{* *} \\
(-2.03)\end{array}$ & $\begin{array}{c}-0.027^{* *} \\
(-2.18)\end{array}$ & & & $\begin{array}{l}-0.025 \\
(-0.98)\end{array}$ & $\begin{array}{l}-0.035 \\
(-1.34)\end{array}$ \\
\hline Disability x House price G. & & & $\begin{array}{c}0.286^{* * *} \\
(3.19)\end{array}$ & $\begin{array}{c}0.289^{* * *} \\
(3.28)\end{array}$ & & & $\begin{array}{l}-0.291 \\
(-1.57)\end{array}$ & $\begin{array}{l}-0.310 \\
(-1.57)\end{array}$ \\
\hline Fam. size G. & $\begin{array}{c}0.423^{* * *} \\
(23.88)\end{array}$ & $\begin{array}{c}0.428^{* * *} \\
(23.73)\end{array}$ & $\begin{array}{c}0.423^{* * *} * \\
(23.99)\end{array}$ & $\begin{array}{c}0.430^{* * *} * \\
(24.09)\end{array}$ & $\begin{array}{c}0.315^{* * *} \\
(14.25)\end{array}$ & $\begin{array}{c}0.319^{* * *} \\
(14.34)\end{array}$ & $\begin{array}{c}0.314^{* * *} \\
(14.15)\end{array}$ & $\begin{array}{c}0.322^{* * *} \\
(14.44)\end{array}$ \\
\hline Age & $\begin{array}{c}-0.008^{* *} \\
(-2.16)\end{array}$ & $\begin{array}{c}-0.008^{* *} \\
(-2.07)\end{array}$ & $\begin{array}{c}-0.008^{* *} \\
(-2.21)\end{array}$ & $\begin{array}{c}-0.006^{*} \\
(-1.70)\end{array}$ & $\begin{array}{l}0.003 \\
(0.66)\end{array}$ & $\begin{array}{l}0.003 \\
(0.54)\end{array}$ & $\begin{array}{l}0.003 \\
(0.66)\end{array}$ & $\begin{array}{l}0.001 \\
(0.18)\end{array}$ \\
\hline Age sq./100 & $\begin{array}{l}0.005 \\
(1.15)\end{array}$ & $\begin{array}{l}0.004 \\
(1.04)\end{array}$ & $\begin{array}{c}0.005 \\
(1.20)\end{array}$ & $\begin{array}{l}0.002 \\
(0.52)\end{array}$ & $\begin{array}{l}-0.007 \\
(-1.23)\end{array}$ & $\begin{array}{l}-0.006 \\
(-1.14)\end{array}$ & $\begin{array}{l}-0.007 \\
(-1.23)\end{array}$ & $\begin{array}{l}-0.005 \\
(-1.01)\end{array}$ \\
\hline Adj. R sq. & 0.104 & 0.106 & 0.105 & 0.102 & 0.056 & 0.057 & 0.056 & 0.044 \\
\hline $\mathrm{F}$ & 161.2 & 127.0 & 167.7 & 134.1 & 68.6 & 58.9 & 59.3 & 41.7 \\
\hline $\mathrm{N}$ & 17,260 & 16,275 & 17,256 & 16,271 & 7,505 & 7,218 & 7,505 & 7,218 \\
\hline
\end{tabular}

Notes: See notes to Table 2. Regressions use the residual measure of house-price appreciation as in Table 6. t-statistics in parentheses. ${ }^{* * *}$ significant at the $1 \%$ level, ${ }^{* *}$ significant at the $5 \%$ level, ${ }^{*}$ significant at the $10 \%$ level. 
Table 11: Risk Sharing Regressions. Food Consumption Away From Home

\begin{tabular}{|c|c|c|c|c|c|c|c|c|}
\hline & \multicolumn{4}{|c|}{ Owners } & \multicolumn{4}{|c|}{ Renters } \\
\hline & $(1)$ & $(2)$ & $(3)$ & $(4)$ & $(5)$ & $(6)$ & $(7)$ & $(8)$ \\
\hline Income $\mathrm{G}$. & $\begin{array}{c}0.178^{* * *} \\
(8.77)\end{array}$ & $\begin{array}{c}0.179^{* * *} \\
(8.56)\end{array}$ & $\begin{array}{c}0.176^{* * *} \\
(8.72)\end{array}$ & & $\begin{array}{l}0.245^{* * *} \\
(9.74)\end{array}$ & $\begin{array}{c}0.229^{* * *} \\
(8.26)\end{array}$ & $\begin{array}{c}0.243^{* * *} \\
(9.49)\end{array}$ & \\
\hline House price $\mathrm{G}$. & $\begin{array}{l}-0.003 \\
(-0.06)\end{array}$ & $\begin{array}{l}-0.003 \\
(-0.07)\end{array}$ & $\begin{array}{c}0.002 \\
(0.03)\end{array}$ & $\begin{array}{l}0.021 \\
(0.38)\end{array}$ & $\begin{array}{l}0.056 \\
(0.58)\end{array}$ & $\begin{array}{c}0.066 \\
(0.73)\end{array}$ & $\begin{array}{c}0.060 \\
(0.66)\end{array}$ & $\begin{array}{c}0.106 \\
(1.11)\end{array}$ \\
\hline Inc. G. x House price G. & $\begin{array}{l}-0.104 \\
(-0.75)\end{array}$ & & & & $\begin{array}{l}0.023 \\
(0.09)\end{array}$ & & & \\
\hline Displaced & & $\begin{array}{c}-0.093^{* * *} \\
(-3.57)\end{array}$ & & $\begin{array}{c}-0.109^{* * *} \\
(-4.18)\end{array}$ & & $\begin{array}{c}-0.098^{* * *} \\
(-3.52)\end{array}$ & & $\begin{array}{c}-0.128^{* * *} \\
(-4.37)\end{array}$ \\
\hline Displaced x House price G. & & $\begin{array}{l}-0.120 \\
(-0.77)\end{array}$ & & $\begin{array}{l}-0.133 \\
(-0.86)\end{array}$ & & $\begin{array}{l}-0.213 \\
(-0.88)\end{array}$ & & $\begin{array}{l}-0.203 \\
(-0.82)\end{array}$ \\
\hline Disabled & & & $\begin{array}{c}-0.058^{* *} \\
(-2.16)\end{array}$ & $\begin{array}{c}-0.073^{* * *} \\
(-2.69)\end{array}$ & & & $\begin{array}{l}-0.052 \\
(-1.08)\end{array}$ & $\begin{array}{l}-0.075 \\
(-1.57)\end{array}$ \\
\hline Disability x House price G. & & & $\begin{array}{l}0.217 \\
(1.27)\end{array}$ & $\begin{array}{l}0.287 \\
(1.63)\end{array}$ & & & $\begin{array}{l}0.213 \\
(0.61)\end{array}$ & $\begin{array}{l}0.258 \\
(0.70)\end{array}$ \\
\hline Fam. size G. & $\begin{array}{l}0.047 \\
(1.58)\end{array}$ & $\begin{array}{l}0.043 \\
(1.38)\end{array}$ & $\begin{array}{l}0.049 \\
(1.62)\end{array}$ & $\begin{array}{l}0.046 \\
(1.48)\end{array}$ & $\begin{array}{l}-0.015 \\
(-0.34)\end{array}$ & $\begin{array}{l}-0.013 \\
(-0.27)\end{array}$ & $\begin{array}{l}-0.016 \\
(-0.36)\end{array}$ & $\begin{array}{l}-0.004 \\
(-0.08)\end{array}$ \\
\hline Age & $\begin{array}{c}0.009 \\
(1.46)\end{array}$ & $\begin{array}{l}0.009 \\
(1.40)\end{array}$ & $\begin{array}{l}0.009 \\
(1.42)\end{array}$ & $\begin{array}{c}0.014^{* *} \\
(2.03)\end{array}$ & $\begin{array}{c}0.016 \\
(1.61)\end{array}$ & $\begin{array}{l}0.014 \\
(1.35)\end{array}$ & $\begin{array}{c}0.015 \\
(1.59)\end{array}$ & $\begin{array}{l}0.010 \\
(1.01)\end{array}$ \\
\hline Age sq./100 & $\begin{array}{c}-0.012^{*} \\
(-1.81)\end{array}$ & $\begin{array}{l}-0.012^{*} \\
(-1.74)\end{array}$ & $\begin{array}{c}-0.012^{*} \\
(-1.76)\end{array}$ & $\begin{array}{c}-0.019^{* *} \\
(-2.59)\end{array}$ & $\begin{array}{c}-0.021^{* *} \\
(-2.00)\end{array}$ & $\begin{array}{c}-0.019^{*} \\
(-1.77)\end{array}$ & $\begin{array}{c}-0.021^{* *} \\
(-1.98)\end{array}$ & $\begin{array}{l}-0.018 \\
(-1.59)\end{array}$ \\
\hline Adj. R sq. & 0.011 & 0.012 & 0.012 & 0.004 & 0.020 & 0.020 & 0.020 & 0.005 \\
\hline $\mathrm{F}$ & 20.2 & 19.4 & 20.1 & 12.1 & 20.4 & 17.7 & 16.9 & 9.7 \\
\hline $\mathrm{N}$ & 14,690 & 13,829 & 14,687 & 13,826 & 5,130 & 4,900 & 5,130 & 4,900 \\
\hline
\end{tabular}

Notes: See notes to Table 2. Regressions use the residual measure of house-price appreciation as in Table 6.

t-statistics in parentheses. ${ }^{* * *}$ significant at the $1 \%$ level, ${ }^{* *}$ significant at the $5 \%$ level, ${ }^{*}$ significant at the $10 \%$ level. 
Table 12: Benchmark Calibration Parameters

Preferences

Cobb-Douglas utility; .2 weight for housing

Discount rate $3.15 \%$; risk aversion 2

DEMOGRAPHICS

One period is two years

Households are born at 24, retire at 66 and die at 84 the lattest.

Mortality shocks: U.S. vital statistics (females), 2003.

INCOME

Variance of permanent (transitory) shocks .01 (.073)

Displacement probability: $3 \%$; income loss $25 \%$

Pension: $50 \%$ of permanent income

MOVING SHOCKS

Current Population Survey, 2005

Housing MARKET

Down payment 20\%; buying (selling) cost 2.5\% (7\%)

TAXES

Income tax rate $20 \%$ (TAXSIM); mortgage interest fully deductible

Housing Prices

Average real appreciation 0; variance .0131;

Rent-to-price ratio $5.7 \%$

OTHER

No income and house-price correlation

No bequest motive but accidental bequests 
Table 13: Summary Statistics of Simulated Data

\begin{tabular}{lrrrr}
\hline Variable & Mean & SD & Min & Max \\
\hline$c_{i t}-\bar{c}_{t}$ & 0.000 & 0.210 & -1.283 & 1.237 \\
$y_{i t}-\bar{y}_{t}$ & 0.000 & 0.533 & -1.491 & 1.525 \\
$h_{m t}-\bar{h}_{t}$ & 0.000 & 0.293 & -0.369 & 0.348 \\
$\left(h_{m t}-\bar{h}_{t}\right) \times\left(y_{i t}-\bar{y}_{t}\right)$ & 0.000 & 0.156 & -0.562 & 0.547 \\
$D_{i t}$ & 0.059 & 0.235 & 0.000 & 1.000 \\
$\left(D_{i t}-\bar{D}_{t}\right) \times\left(h_{m t}-\bar{h}_{t}\right)$ & 0.000 & 0.069 & -0.347 & 0.328 \\
Owner & 0.643 & 0.479 & 0.000 & 1.000 \\
Age & 45.8 & 11.0 & 28 & 64 \\
\hline
\end{tabular}

Notes: Variable definitions as follows: $c_{i t}$ is the (4-year) log difference of consumption for individual $i$ in year $t, y_{i t}$ is the log difference of income, and $\bar{c}_{t}\left(\bar{y}_{t}\right)$ is the mean log consumption (income) difference in period $t . h_{m t}$ is the log difference in house prices in the region where individual $i$ lives, while $\bar{h}_{t}$ is the mean $\log$ difference in house prices for all regions in period $t$. $D_{i t}$ is the displacement shock indicator. 
Table 14: Risk Sharing Regressions in the Model. Full Sample (of ages 28-64)

\begin{tabular}{lccccc}
\hline \hline & $(1)$ & $(2)$ & $(3)$ & $(4)$ & $(5)$ \\
\hline & & & & & \\
Income Growth & $0.17^{* * *}$ & $0.17^{* * *}$ & $0.16^{* * *}$ & & $0.16^{* * *}$ \\
& $(95.84)$ & $(181.98)$ & $(96.22)$ & & $(171.90)$ \\
House Price Growth & & $0.15^{* * *}$ & $0.15^{* * *}$ & $0.15^{* * *}$ & $0.15^{* * *}$ \\
& & $(97.21)$ & $(103.22)$ & $(90.11)$ & $(102.95)$ \\
Income G. $\times$ House Price G. & & $-0.04^{* * *}$ & & & $-0.04^{* * *}$ \\
& & $(-17.03)$ & & & $(-17.94)$ \\
Displaced & & & $-0.17^{* * *}$ & $-0.22^{* * *}$ & $-0.17^{* * *}$ \\
& & & $(-100.49)$ & $(-138.35)$ & $(-104.26)$ \\
Displaced $\times$ House Price G. & & & $0.04^{* * *}$ & $0.04^{* * *}$ & $0.03^{* * *}$ \\
& & & $(7.47)$ & $(7.60)$ & $(5.22)$ \\
Age & $-0.01^{* * *}$ & $-0.01^{* * *}$ & $-0.01^{* * *}$ & $-0.02^{* * *}$ & $-0.01^{* * *}$ \\
& $(-34.31)$ & $(-32.72)$ & $(-36.10)$ & $(-58.17)$ & $(-36.01)$ \\
Age sq./100 & $0.01^{* * *}$ & $0.01^{* * *}$ & $0.01^{* * *}$ & $0.02^{* * *}$ & $0.01^{* * *}$ \\
& $(24.31)$ & $(23.63)$ & $(25.10)$ & $(49.31)$ & $(25.13)$ \\
Adj. R sq. & 0.251 & 0.284 & 0.319 & 0.127 & 0.320 \\
F & 17361.1 & 15243.9 & 13471.9 & 4496.1 & 14127.7 \\
N & 274,291 & 274,291 & 274,291 & 274,291 & 274,291 \\
\hline
\end{tabular}

Notes: We simulate 27 regions. Regions 1-9 experience house-price depreciation; regions 10-18 experience no changes in house prices, and regions 19-27 experience house-price appreciation.

Regressions of the form:

$c_{i t}-\bar{c}_{t}=\mu+\alpha\left(y_{i t}-\bar{y}_{t}\right)+\beta\left(h_{m t}-\bar{h}_{t}\right)+\gamma\left(y_{i t}-\bar{y}_{t}\right) \times\left(h_{m t}-\bar{h}_{t}\right)+\xi\left(D_{i t}-\bar{D}_{t}\right)+\zeta\left(D_{i t}-\bar{D}_{t}\right) \times\left(h_{m t}-\bar{h}_{t}\right)+\left(X_{i t}-\bar{X}_{t}\right)^{\prime} \delta+\varepsilon_{i t}$.

$c_{i t}$ is the (4-year) log difference of consumption for individual $i$ in year $t, y_{i t}$ is the log difference of income, and $\bar{y}_{t}$ is the mean $\log$ income difference in period $t . h_{m t}$ is the log difference in house prices in the region where individual $i$ lives, while $\bar{h}_{t}$ is the mean log difference in house prices for all regions during period $t$. $D_{i t}$ is the displacement shock indicator.

Prais-Winsten regressions. Robust standard errors in the regressions clustered by region. t-statistics in parentheses. *** significant at the $1 \%$ level, ** significant at the $5 \%$ level, * significant at the $10 \%$ level. 
Table 15: Risk Sharing Regressions in the Model. Owners vs. Renters

\begin{tabular}{|c|c|c|c|c|c|c|}
\hline & \multicolumn{3}{|c|}{ Owners } & \multicolumn{3}{|c|}{ Renters } \\
\hline & $(1)$ & $(2)$ & $(3)$ & $(4)$ & $(5)$ & $(6)$ \\
\hline Income Growth & $\begin{array}{c}0.13^{* * *} \\
(213.07)\end{array}$ & $\begin{array}{c}0.12^{* * *} \\
(102.04)\end{array}$ & & $\begin{array}{c}0.29^{* * *} \\
(213.95)\end{array}$ & $\begin{array}{c}0.28^{* * *} \\
(175.62)\end{array}$ & \\
\hline House Price Growth & $\begin{array}{c}0.22^{* * *} \\
(132.99)\end{array}$ & $\begin{array}{c}0.22^{* * *} \\
(135.15)\end{array}$ & $\begin{array}{c}0.22^{* * *} \\
(116.67)\end{array}$ & $\begin{array}{c}0.00 \\
(0.94)\end{array}$ & $\begin{array}{c}0.00 \\
(1.44)\end{array}$ & $\begin{array}{c}0.01 \\
(1.33)\end{array}$ \\
\hline Income G. $\times$ House Price G. & $\begin{array}{c}-0.02^{* * *} \\
(-13.28)\end{array}$ & & & $\begin{array}{c}0.01^{* * *} \\
(2.80)\end{array}$ & & \\
\hline Displaced & & $\begin{array}{l}-0.16^{* * *} \\
(-101.34)\end{array}$ & $\begin{array}{l}-0.19^{* * *} \\
(-131.32)\end{array}$ & & $\begin{array}{c}-0.20 * * * \\
(-51.52)\end{array}$ & $\begin{array}{c}-0.27^{* * *} \\
(-71.82)\end{array}$ \\
\hline Displaced $\times$ House Price G. & & $\begin{array}{c}0.04^{* * *} \\
(8.51)\end{array}$ & $\begin{array}{c}0.04^{* * *} \\
(9.08)\end{array}$ & & $\begin{array}{c}0.01 \\
(0.99)\end{array}$ & $\begin{array}{c}0.01 \\
(0.82)\end{array}$ \\
\hline Age & $\begin{array}{c}0.02^{* * * *} \\
(46.48)\end{array}$ & $\begin{array}{c}0.02^{* * *} \\
(46.26)\end{array}$ & $\begin{array}{c}0.01^{* * * *} \\
(20.34)\end{array}$ & $\begin{array}{c}-0.04^{* * *} \\
(-50.30)\end{array}$ & $\begin{array}{c}-0.04^{* * *} \\
(-48.97)\end{array}$ & $\begin{array}{c}-0.06^{* * *} \\
(-64.34)\end{array}$ \\
\hline Age sq./100 & $\begin{array}{c}-0.02^{* * *} \\
(-42.19)\end{array}$ & $\begin{array}{c}-0.02^{* * *} \\
(-41.96)\end{array}$ & $\begin{array}{c}-0.01^{* * * *} \\
(-22.55)\end{array}$ & $\begin{array}{c}0.04^{* * *} \\
(40.25)\end{array}$ & $\begin{array}{c}0.04^{* * *} \\
(39.63)\end{array}$ & $\begin{array}{c}0.06^{* * *} \\
(55.16)\end{array}$ \\
\hline Adj. R sq. & 0.301 & 0.347 & 0.177 & 0.436 & 0.459 & 0.168 \\
\hline $\mathrm{F}$ & 13070.0 & 13483.8 & 4445.9 & 12860.0 & 9514.2 & 3361.2 \\
\hline $\mathrm{N}$ & 176,246 & 176,246 & 176,246 & 69,329 & 69,329 & 69,329 \\
\hline
\end{tabular}

Notes: See notes to Table 14. Prais-Winsten regressions. Robust standard errors in the regressions clustered by region. t-statistics in parentheses. $* * *$ significant at the $1 \%$ level, $* *$ significant at the $5 \%$ level, * significant at the $10 \%$ level. 
Table 16: Risk Sharing Regressions in the Model. Young vs. Old

\begin{tabular}{|c|c|c|c|c|c|c|c|c|}
\hline & \multicolumn{4}{|c|}{ YOUNG } & \multicolumn{4}{|c|}{ OLD } \\
\hline & \multicolumn{2}{|c|}{ Owner } & \multicolumn{2}{|c|}{ Renter } & \multicolumn{2}{|c|}{ Owner } & \multicolumn{2}{|c|}{ Renter } \\
\hline & $(1)$ & $(2)$ & $(3)$ & $(4)$ & $(5)$ & $(6)$ & $(7)$ & $(8)$ \\
\hline Income Growth & $\begin{array}{l}0.13^{* * *} \\
(120.59)\end{array}$ & $\begin{array}{c}0.13^{* * *} \\
(90.35)\end{array}$ & $\begin{array}{l}0.37^{* * *} \\
(230.48)\end{array}$ & $\begin{array}{c}0.36^{* * *} \\
(182.56)\end{array}$ & $\begin{array}{l}0.12^{* * *} \\
(163.91)\end{array}$ & $\begin{array}{c}0.12^{* * *} \\
(86.30)\end{array}$ & $\begin{array}{c}0.13^{* * *} \\
(24.61)\end{array}$ & $\begin{array}{c}0.12^{* * *} \\
(22.42)\end{array}$ \\
\hline House Price Growth & $\begin{array}{c}0.18^{* * *} \\
(73.12)\end{array}$ & $\begin{array}{c}0.18^{* * *} \\
(78.17)\end{array}$ & $\begin{array}{c}0.00 \\
(0.67)\end{array}$ & $\begin{array}{c}0.01 \\
(1.66)\end{array}$ & $\begin{array}{c}0.24^{* * *} \\
(95.89)\end{array}$ & $\begin{array}{c}0.25^{* * *} \\
(94.66)\end{array}$ & $\begin{array}{c}0.01 \\
(1.68)\end{array}$ & $\begin{array}{c}0.01 \\
(1.22)\end{array}$ \\
\hline Income G. $\times$ House Price G. & $\begin{array}{c}-0.02^{* * *} \\
(-5.95)\end{array}$ & & $\begin{array}{c}0.02^{* * *} \\
(3.22)\end{array}$ & & $\begin{array}{c}-0.02^{* * *} \\
(-7.57)\end{array}$ & & $\begin{array}{l}-0.03 \\
(-1.65)\end{array}$ & \\
\hline Displaced & & $\begin{array}{l}-0.18^{* * *} \\
(-55.76)\end{array}$ & & $\begin{array}{c}-0.16^{* * *} \\
(-34.57)\end{array}$ & & $\begin{array}{c}-0.14^{* * *} \\
(-58.69)\end{array}$ & & $\begin{array}{c}-0.25^{* * *} \\
(-26.03)\end{array}$ \\
\hline Displaced $\times$ House Price G. & & $\begin{array}{c}0.03^{* *} \\
(2.26)\end{array}$ & & $\begin{array}{c}0.02 \\
(1.37)\end{array}$ & & $\begin{array}{c}0.05^{* * *} \\
(6.51)\end{array}$ & & $\begin{array}{l}-0.04 \\
(-0.94)\end{array}$ \\
\hline Age & $\begin{array}{c}0.05^{* * *} \\
(11.33)\end{array}$ & $\begin{array}{c}0.05^{* * *} \\
(12.31)\end{array}$ & $\begin{array}{c}-0.10^{* * *} \\
(-11.83)\end{array}$ & $\begin{array}{c}-0.10^{* * *} \\
(-11.66)\end{array}$ & $\begin{array}{c}0.02^{* * *} \\
(5.73)\end{array}$ & $\begin{array}{c}0.02^{* * *} \\
(5.59)\end{array}$ & $\begin{array}{c}0.04^{* *} \\
(2.17)\end{array}$ & $\begin{array}{c}0.04^{* *} \\
(2.20)\end{array}$ \\
\hline Age sq./100 & $\begin{array}{c}-0.07^{* * *} \\
(-10.01)\end{array}$ & $\begin{array}{c}-0.07^{* * *} \\
(-10.86)\end{array}$ & $\begin{array}{c}0.12^{* * *} \\
(9.71)\end{array}$ & $\begin{array}{c}0.12^{* * *} \\
(9.50)\end{array}$ & $\begin{array}{c}-0.02^{* * *} \\
(-6.65)\end{array}$ & $\begin{array}{c}-0.02^{* * *} \\
(-6.49)\end{array}$ & $\begin{array}{c}-0.04^{* *} \\
(-2.36)\end{array}$ & $\begin{array}{c}-0.04^{* *} \\
(-2.36)\end{array}$ \\
\hline Adj. R sq. & 0.265 & 0.318 & 0.532 & 0.546 & 0.334 & 0.373 & 0.126 & 0.176 \\
\hline $\mathrm{F}$ & 5179.7 & 5358.3 & 21189.5 & 12398.6 & 6542.7 & 7550.6 & 147.7 & 310.8 \\
\hline $\mathrm{N}$ & 36,680 & 36,680 & 43,287 & 43,287 & 86,489 & 86,489 & 6,309 & 6,309 \\
\hline
\end{tabular}

Notes: See notes to Table 14. Young is 24-40, old is 50-65. Prais-Winsten regressions. Robust standard errors in the regressions clustered by region. t-statistics in parentheses. *** significant at the $1 \%$ level, ${ }^{* *}$ significant at the $5 \%$ level, $*$ significant at the $10 \%$ level. 
Table 17: Parameters for Alternative Calibrations

\begin{tabular}{lcccc}
\hline \hline & $\begin{array}{c}\text { Discount } \\
\text { Rate } \%\end{array}$ & $\begin{array}{c}\text { Housing } \\
\text { Parameter }\end{array}$ & $\begin{array}{c}\text { Minimum } \\
\text { House size }\end{array}$ & $\begin{array}{c}\text { Bequest } \\
\text { Parameter }\end{array}$ \\
\hline Acc. Bequest/No correlation & 3.15 & 0.2 & 1.65 & 0 \\
Acc. Bequest/Correlation & 3.33 & 0.23 & 1.55 & 0 \\
Bequest/No correlation & 4.5 & 0.19 & 1.68 & 1.65 \\
Bequest/Correlation & 4.5 & 0.21 & 1.65 & 1.4 \\
CES Acc. Bequest/ No correlation & 2.95 & 0.61 & 1.64 & 0 \\
CES Bequest/correlation & 4.02 & 0.62 & 1.67 & 1 \\
\hline
\end{tabular}


Table 18: Risk Sharing Regressions in the Model for Owners under Different Specifications

\begin{tabular}{|c|c|c|c|c|c|c|c|c|}
\hline & \multicolumn{4}{|c|}{ Owners } & \multicolumn{4}{|c|}{ Renters } \\
\hline & \multicolumn{2}{|c|}{ Accidental Bequests } & \multicolumn{2}{|c|}{ Bequest Motive } & \multicolumn{2}{|c|}{ Accidental Bequests } & \multicolumn{2}{|c|}{ Bequest Motive } \\
\hline & $\begin{array}{c}\text { No corr. } \\
\text { (1) }\end{array}$ & $\begin{array}{c}\text { Corr. } \\
(2)\end{array}$ & $\begin{array}{c}\text { No corr. } \\
(3)\end{array}$ & $\begin{array}{c}\text { Corr. } \\
(4)\end{array}$ & $\begin{array}{c}\text { No corr. } \\
\quad(5)\end{array}$ & $\begin{array}{c}\text { Corr. } \\
(6)\end{array}$ & $\begin{array}{c}\text { No corr. } \\
\quad(7)\end{array}$ & $\begin{array}{c}\text { Corr. } \\
(8)\end{array}$ \\
\hline \multirow[t]{2}{*}{ Income Growth } & $0.12^{* * *}$ & $0.12^{* * *}$ & $0.12^{* * *}$ & $0.12^{* * *}$ & $0.28^{* * *}$ & $0.31^{* * *}$ & $0.19^{* * *}$ & $0.19^{* * *}$ \\
\hline & $(194.15)$ & $(283.68)$ & $(174.01)$ & $(193.39)$ & $(195.18)$ & $(212.28)$ & $(136.35)$ & $(140.79)$ \\
\hline \multirow[t]{2}{*}{ House Price Growth } & $0.22^{* * *}$ & $0.33^{* * *}$ & $0.24^{* * *}$ & $0.34^{* * *}$ & 0.00 & $0.13^{* * *}$ & -0.00 & $0.15^{* * *}$ \\
\hline & $(135.89)$ & $(200.50)$ & $(153.78)$ & $(205.09)$ & $(0.89)$ & $(41.21)$ & $(-0.37)$ & $(57.27)$ \\
\hline \multirow[t]{2}{*}{ Income G. $\times$ House Price G. } & $-0.02^{* * *}$ & 0.00 & $-0.02^{* * *}$ & 0.00 & $0.01^{* * *}$ & 0.00 & -0.00 & 0.01 \\
\hline & $(-11.42)$ & $(0.60)$ & $(-11.54)$ & $(0.72)$ & $(2.84)$ & $(0.41)$ & $(-0.99)$ & $(1.42)$ \\
\hline \multirow[t]{2}{*}{ Displaced } & $-0.16^{* * *}$ & $-0.16^{* * *}$ & $-0.15^{* * *}$ & $-0.15^{* * *}$ & $-0.19^{* * *}$ & $-0.18^{* * *}$ & $-0.20^{* * *}$ & $-0.19^{* * *}$ \\
\hline & $(-99.83)$ & $-121.87)$ & $(-107.66)$ & $(-89.65)$ & $(-49.45)$ & $(-50.68)$ & $(-73.04)$ & $(-59.14)$ \\
\hline \multirow[t]{2}{*}{ Displaced $\times$ House Price G. } & $0.03^{* * *}$ & $0.03^{* * *}$ & $0.03^{* * *}$ & $0.03^{* * *}$ & 0.02 & $0.03^{* *}$ & 0.01 & 0.02 \\
\hline & $(6.97)$ & $(6.04)$ & $(6.33)$ & $(4.57)$ & (1.03) & (2.37) & $(0.67)$ & $(1.55)$ \\
\hline \multirow[t]{2}{*}{ Age } & $0.02^{* * *}$ & $0.01^{* * *}$ & $0.02^{* * *}$ & $0.01^{* * *}$ & $-0.04^{* * *}$ & $-0.04^{* * *}$ & $0.01^{* * *}$ & $0.01^{* * *}$ \\
\hline & & $(35.54)$ & $(46.30)$ & $(32.75)$ & $(-48.99)$ & $(-52.59)$ & $(17.18)$ & $(13.05)$ \\
\hline \multirow[t]{2}{*}{ Age sq./100 } & $-0.02^{* * *}$ & $-0.01^{* * *}$ & $-0.02^{* * *}$ & $-0.01^{* * *}$ & $0.04^{* * *}$ & $0.04^{* * *}$ & $-0.01^{* * *}$ & $-0.02^{* * *}$ \\
\hline & $(-42.26)$ & $(-35.32)$ & $(-39.61)$ & $(-34.59)$ & $(39.54)$ & $(43.61)$ & $(-18.98)$ & $(-13.37)$ \\
\hline Adj. R sq. & 0.348 & 0.442 & 0.363 & 0.459 & 0.459 & 0.511 & 0.323 & 0.364 \\
\hline $\mathrm{F}$ & 10038.2 & 32614.2 & 12482.5 & 20132.6 & 12217.7 & 12764.9 & 5482.1 & 5769.5 \\
\hline $\mathrm{N}$ & 176,246 & 177,508 & 164,513 & 154,230 & 69,329 & 70,388 & 78,310 & 90,986 \\
\hline
\end{tabular}

Notes: See notes to Table 14.

Prais-Winsten regressions. Robust standard errors in the regressions clustered by region. t-statistics in parentheses. *** significant at the $1 \%$ level, ** significant at the $5 \%$ level, * significant at the $10 \%$ level. 
Table A-1: Risk Sharing Regressions. House Price Residuals. Changes in Household Disposable InCOMe

\begin{tabular}{|c|c|c|c|c|c|c|c|c|}
\hline & \multicolumn{4}{|c|}{ Owners } & \multicolumn{4}{|c|}{ Renters } \\
\hline & (1) & $(2)$ & (3) & (4) & (5) & (6) & (7) & (8) \\
\hline Income G. & $\begin{array}{c}0.101^{* * *} \\
(9.90)\end{array}$ & $\begin{array}{c}0.101^{* * *} \\
(8.98)\end{array}$ & $\begin{array}{c}0.100^{* * *} \\
(9.80)\end{array}$ & & $\begin{array}{c}0.188^{* * *} * \\
(10.69)\end{array}$ & $\begin{array}{c}0.178^{* * *} \\
(9.59)\end{array}$ & $\begin{array}{c}0.186^{* * *} \\
(10.26)\end{array}$ & \\
\hline House price $\mathrm{G}$. & $\begin{array}{c}0.102^{* * *} \\
(4.59)\end{array}$ & $\begin{array}{c}0.105^{* * *} \\
(4.54)\end{array}$ & $\begin{array}{c}0.103^{* * *} \\
(4.58)\end{array}$ & $\begin{array}{c}0.114^{* * *} \\
(4.88)\end{array}$ & $\begin{array}{c}0.106^{* *} \\
(2.50)\end{array}$ & $\begin{array}{c}0.096^{* *} \\
(2.31)\end{array}$ & $\begin{array}{c}0.101^{* *} \\
(2.39)\end{array}$ & $\begin{array}{c}0.117^{* * *} \\
(2.72)\end{array}$ \\
\hline Inc. G. x House price G. & $\begin{array}{c}-0.149^{* *} \\
(-2.18)\end{array}$ & & & & $\begin{array}{l}-0.129 \\
(-1.01)\end{array}$ & & & \\
\hline Displaced & & $\begin{array}{c}-0.038^{* * *} \\
(-3.11)\end{array}$ & & $\begin{array}{c}-0.046^{* * *} \\
(-3.77)\end{array}$ & & $\begin{array}{c}-0.061^{* * *} \\
(-3.44)\end{array}$ & & $\begin{array}{c}-0.082^{* * *} \\
(-4.69)\end{array}$ \\
\hline Displaced x House price G. & & $\begin{array}{c}0.140^{*} \\
(1.75)\end{array}$ & & $\begin{array}{c}0.134^{*} \\
(1.65)\end{array}$ & & $\begin{array}{c}0.077 \\
(0.57)\end{array}$ & & $\begin{array}{c}0.062 \\
(0.46)\end{array}$ \\
\hline Disabled & & & $\begin{array}{c}-0.032^{* * *} \\
(-2.81)\end{array}$ & $\begin{array}{c}-0.034^{* * *} \\
(-2.99)\end{array}$ & & & $\begin{array}{c}-0.048^{* *} \\
(-2.28)\end{array}$ & $\begin{array}{c}-0.056^{* *} \\
(-2.49)\end{array}$ \\
\hline Disability x House price G. & & & $\begin{array}{c}0.257^{* * *} \\
(3.06)\end{array}$ & $\begin{array}{c}0.261^{* * *} \\
(3.05)\end{array}$ & & & $\begin{array}{l}-0.133 \\
(-0.79)\end{array}$ & $\begin{array}{l}-0.164 \\
(-0.92)\end{array}$ \\
\hline Fam. size G. & $\begin{array}{c}0.327^{* * * *} \\
(22.78)\end{array}$ & $\begin{array}{c}0.330^{* * *} \\
(22.57)\end{array}$ & $\begin{array}{c}0.328^{* * *} \\
(22.89)\end{array}$ & $\begin{array}{c}0.337^{* * *} \\
(22.79)\end{array}$ & $\begin{array}{c}0.243^{* * *} \\
(13.23)\end{array}$ & $\begin{array}{c}0.248^{* * *} \\
(13.19)\end{array}$ & $\begin{array}{c}0.242^{* * *} \\
(13.11)\end{array}$ & $\begin{array}{c}0.260^{* * *} \\
(14.32)\end{array}$ \\
\hline Age & $\begin{array}{c}-0.006^{*} \\
(-1.82)\end{array}$ & $\begin{array}{l}-0.005 \\
(-1.55)\end{array}$ & $\begin{array}{c}-0.006^{*} \\
(-1.89)\end{array}$ & $\begin{array}{l}-0.004 \\
(-1.25)\end{array}$ & $\begin{array}{l}0.003 \\
(0.69)\end{array}$ & $\begin{array}{l}0.002 \\
(0.56)\end{array}$ & $\begin{array}{l}0.003 \\
(0.67)\end{array}$ & $\begin{array}{l}-0.000 \\
(-0.11)\end{array}$ \\
\hline Age sq./100 & $\begin{array}{l}0.002 \\
(0.65)\end{array}$ & $\begin{array}{l}0.002 \\
(0.44)\end{array}$ & $\begin{array}{l}0.002 \\
(0.73)\end{array}$ & $\begin{array}{l}-0.000 \\
(-0.05)\end{array}$ & $\begin{array}{l}-0.006 \\
(-1.39)\end{array}$ & $\begin{array}{l}-0.006 \\
(-1.36)\end{array}$ & $\begin{array}{l}-0.006 \\
(-1.37)\end{array}$ & $\begin{array}{l}-0.004 \\
(-0.94)\end{array}$ \\
\hline Adj. R sq. & 0.088 & 0.088 & 0.088 & 0.080 & 0.056 & 0.057 & 0.057 & 0.039 \\
\hline $\mathrm{F}$ & 171.5 & 132.5 & 170.6 & 130.4 & 88.0 & 79.1 & 75.2 & 31.5 \\
\hline $\mathrm{N}$ & 17,276 & 16,287 & 17,272 & 16,283 & 7,481 & 7,196 & 7,481 & 7,196 \\
\hline
\end{tabular}

Notes: See notes to Table 2. Regressions use the residual measure of house-price appreciation as in Table 6. The income measure used is an estimate of household disposable non-financial income.

*** significant at the $1 \%$ level, ** significant at the $5 \%$ level, * significant at the $10 \%$ level. 
Table A-2: Food Equation. CEX Data: 1980-2002

\begin{tabular}{|c|c|c|c|c|}
\hline & $\begin{array}{l}\text { OLS, Indep. var.: } \\
\text { Nondur. cons. }\end{array}$ & $\begin{array}{l}\text { IV, Indep. var.: } \\
\text { Nondur. cons. }\end{array}$ & $\begin{array}{l}\text { OLS, Indep. var.: } \\
\text { Nondur. cons.+hous. }\end{array}$ & $\begin{array}{c}\text { IV, Indep. var.: } \\
\text { Nondur. cons.+hous. }\end{array}$ \\
\hline \multirow[t]{2}{*}{ Log nondurable cons. } & $0.606^{* * *}$ & $0.788^{* * *}$ & $0.579^{* * *}$ & $0.775^{* * *}$ \\
\hline & $(73.71)$ & $(11.00)$ & $(60.51)$ & $(9.58)$ \\
\hline \multirow[t]{2}{*}{ Log nondurable cons. $\times 1980$} & $0.069^{* * *}$ & -0.032 & $0.128^{* * *}$ & $0.113^{* *}$ \\
\hline & $(4.97)$ & $(-0.74)$ & $(7.74)$ & $(2.28)$ \\
\hline \multirow[t]{2}{*}{ Log nondurable cons. $\times 1981$} & $0.066^{* * *}$ & -0.005 & $0.116^{* * *}$ & $0.110^{* * *}$ \\
\hline & $(6.16)$ & $(-0.14)$ & $(9.09)$ & $(2.92)$ \\
\hline \multirow[t]{2}{*}{ Log nondurable cons. $\times 1982$} & $0.073^{* * *}$ & 0.020 & $0.104^{* * *}$ & $0.106^{* * *}$ \\
\hline & $(8.29)$ & $(0.71)$ & $(10.22)$ & $(3.50)$ \\
\hline \multirow[t]{2}{*}{ Log nondurable cons. $\times 1983$} & $0.081^{* * *}$ & 0.040 & $0.104^{* * *}$ & $0.112^{* * *}$ \\
\hline & $(10.25)$ & $(1.53)$ & $(11.39)$ & $(4.14)$ \\
\hline \multirow[t]{2}{*}{ Log nondurable cons. $\times 1984$} & $0.075^{* * *}$ & 0.044 & $0.098 * * *$ & $0.107^{* * *}$ \\
\hline & $(8.14)$ & $(1.55)$ & $(9.23)$ & $(3.70)$ \\
\hline \multirow[t]{2}{*}{ Log nondurable cons. $\times 1985$} & $0.076^{* * *}$ & $0.050^{*}$ & $0.097^{* * *}$ & $0.108^{* * *}$ \\
\hline & $(8.27)$ & $(1.79)$ & $(9.13)$ & $(3.78)$ \\
\hline \multirow[t]{2}{*}{ Log nondurable cons. $\times 1986$} & $0.067^{* * *}$ & 0.029 & $0.087^{* * *}$ & $0.093^{* * *}$ \\
\hline & $(8.58)$ & $(1.23)$ & $(9.72)$ & $(3.72)$ \\
\hline \multirow[t]{2}{*}{ Log nondurable cons. $\times 1987$} & $0.054^{* * *}$ & 0.014 & $0.076^{* * *}$ & $0.079^{* * *}$ \\
\hline & $(9.37)$ & $(0.68)$ & $(11.40)$ & $(3.64)$ \\
\hline \multirow[t]{2}{*}{ Log nondurable cons. $\times 1988$} & $0.055^{* * *}$ & 0.011 & $0.078^{* * *}$ & $0.075^{* * *}$ \\
\hline & $(9.67)$ & $(0.59)$ & $(11.81)$ & $(3.71)$ \\
\hline \multirow[t]{2}{*}{ Log nondurable cons. $\times 1989$} & $0.048^{* * *}$ & 0.015 & $0.069^{* * *}$ & $0.067^{* * *}$ \\
\hline & $(8.38)$ & $(0.79)$ & $(10.25)$ & $(3.37)$ \\
\hline \multirow[t]{2}{*}{ Log nondurable cons. $\times 1990$} & $0.041^{* * *}$ & 0.017 & $0.058^{* * *}$ & $0.059^{* * *}$ \\
\hline & $(6.11)$ & $(0.82)$ & $(7.47)$ & $(2.69)$ \\
\hline \multirow[t]{2}{*}{ Log nondurable cons. $\times 1991$} & $0.026^{* * *}$ & -0.009 & $0.045^{* * *}$ & $0.041^{* *}$ \\
\hline & $(4.79)$ & $(-0.57)$ & $(7.09)$ & $(2.30)$ \\
\hline \multirow[t]{2}{*}{ Log nondurable cons. $\times 1992$} & $0.024^{* * *}$ & -0.013 & $0.042^{* * *}$ & $0.037^{*}$ \\
\hline & $(3.58)$ & $(-0.72)$ & $(5.57)$ & $(1.82)$ \\
\hline Log nondurable cons. $\times 1993$ & $0.023^{* * *}$ & -0.007 & $0.041^{* * *}$ & $0.037^{*}$ \\
\hline
\end{tabular}




\begin{tabular}{|c|c|c|c|c|}
\hline & $\begin{array}{l}\text { OLS, Indep. var.: } \\
\text { Nondur. cons. }\end{array}$ & $\begin{array}{l}\text { IV, Indep. var.: } \\
\text { Nondur. cons. }\end{array}$ & $\begin{array}{c}\text { OLS, Indep. var.: } \\
\text { Nondur. cons.+hous. }\end{array}$ & $\begin{array}{c}\text { IV, Indep. var.: } \\
\text { Nondur. cons.+hous. }\end{array}$ \\
\hline & $(3.30)$ & $(-0.38)$ & $(5.02)$ & $(1.78)$ \\
\hline \multirow[t]{2}{*}{ Log nondurable cons. $\times 1994$} & $0.025^{* * *}$ & -0.000 & $0.040^{* * *}$ & $0.038^{* *}$ \\
\hline & $(3.90)$ & $(-0.00)$ & $(5.53)$ & $(2.05)$ \\
\hline \multirow[t]{2}{*}{ Log nondurable cons. $\times 1995$} & $0.017^{* *}$ & -0.006 & $0.033^{* * *}$ & 0.028 \\
\hline & $(2.18)$ & $(-0.26)$ & $(3.75)$ & $(1.24)$ \\
\hline \multirow[t]{2}{*}{ Log nondurable cons. $\times 1996$} & $0.013^{*}$ & -0.005 & $0.029^{* * *}$ & 0.025 \\
\hline & $(1.78)$ & $(-0.26)$ & $(3.41)$ & $(1.16)$ \\
\hline \multirow[t]{2}{*}{ Log nondurable cons. $\times 1997$} & $0.015^{* *}$ & 0.003 & $0.027^{* * *}$ & 0.024 \\
\hline & $(2.19)$ & $(0.16)$ & $(3.47)$ & $(1.26)$ \\
\hline \multirow[t]{2}{*}{ Log nondurable cons. $\times 1998$} & 0.006 & -0.010 & $0.018^{* * *}$ & 0.014 \\
\hline & $(1.60)$ & $(-0.94)$ & $(3.97)$ & $(1.16)$ \\
\hline \multirow[t]{2}{*}{ Log nondurable cons. $\times 1999$} & -0.001 & $-0.021^{* *}$ & $0.010^{* *}$ & 0.003 \\
\hline & $(-0.22)$ & $(-2.02)$ & $(2.41)$ & $(0.27)$ \\
\hline \multirow[t]{2}{*}{ Log nondurable cons. $\times 2000$} & -0.002 & -0.015 & 0.010 & 0.003 \\
\hline & $(-0.24)$ & $(-0.66)$ & $(1.10)$ & $(0.12)$ \\
\hline \multirow[t]{2}{*}{ Log nondurable cons. $\times 2001$} & $0.024^{* * *}$ & $0.043^{* * *}$ & $0.017^{* * *}$ & $0.029^{*}$ \\
\hline & $(4.32)$ & $(2.87)$ & $(2.73)$ & $(1.81)$ \\
\hline \multirow[t]{2}{*}{ Log nondurable cons. $\times$ HS and more } & $0.041^{* * *}$ & $0.108^{* *}$ & $0.049^{* * *}$ & $0.142^{* *}$ \\
\hline & $(5.62)$ & $(2.15)$ & $(5.76)$ & $(2.17)$ \\
\hline \multirow[t]{2}{*}{ Log nondurable cons. $\times$ coll. and more } & $-0.023^{* * *}$ & $0.096^{* *}$ & 0.002 & $0.145^{* *}$ \\
\hline & $(-2.86)$ & $(1.98)$ & $(0.18)$ & $(2.42)$ \\
\hline \multirow[t]{2}{*}{ Log food CPI } & 0.478 & -1.296 & 1.123 & 0.721 \\
\hline & $(0.36)$ & $(-0.36)$ & $(0.71)$ & $(0.18)$ \\
\hline \multirow[t]{2}{*}{ Log transport. CPI } & 0.882 & 1.003 & 0.079 & 0.709 \\
\hline & $(0.84)$ & $(0.34)$ & $(0.06)$ & $(0.22)$ \\
\hline \multirow[t]{2}{*}{ Log fuel/util. CPI } & $-2.238^{* * *}$ & $-4.475^{* * *}$ & -1.076 & -2.579 \\
\hline & $(-3.61)$ & $(-2.58)$ & $(-1.43)$ & $(-1.31)$ \\
\hline \multirow[t]{2}{*}{ Log alcohol CPI } & 1.375 & 3.699 & 0.970 & 1.886 \\
\hline & $(1.16)$ & $(1.17)$ & $(0.68)$ & $(0.53)$ \\
\hline \multirow[t]{2}{*}{ White } & $0.047^{* * *}$ & 0.014 & $0.052^{* * *}$ & 0.014 \\
\hline & $(11.58)$ & $(1.15)$ & $(12.18)$ & $(1.09)$ \\
\hline \multirow[t]{2}{*}{ Fam. size } & $0.074^{* * *}$ & $0.055^{* * *}$ & $0.087^{* * *}$ & $0.069^{* * *}$ \\
\hline & $(64.67)$ & $(9.22)$ & $(71.85)$ & $(13.33)$ \\
\hline \multirow[t]{2}{*}{ HS and more } & $-0.416^{* * *}$ & $-1.088^{* *}$ & $-0.512^{* * *}$ & $-1.464^{* *}$ \\
\hline & $(-6.36)$ & $(-2.36)$ & $(-6.38)$ & $(-2.36)$ \\
\hline Coll. and more & $0.157^{* *}$ & $-1.073^{* *}$ & -0.084 & $-1.631^{* * *}$ \\
\hline
\end{tabular}




\begin{tabular}{|c|c|c|c|c|}
\hline & $\begin{array}{c}\text { OLS, Indep. var. } \\
\text { Nondur. cons. }\end{array}$ & $\begin{array}{l}\text { IV, Indep. var.: } \\
\text { Nondur. cons. }\end{array}$ & $\begin{array}{c}\text { OLS, Indep. var.: } \\
\text { Nondur. cons.+hous. }\end{array}$ & $\begin{array}{c}\text { IV, Indep. var.: } \\
\text { Nondur. cons.+hous. }\end{array}$ \\
\hline & $(2.11)$ & $(-2.42)$ & $(-0.92)$ & $(-2.85)$ \\
\hline \multirow[t]{2}{*}{ Male head } & $0.066^{* * *}$ & $0.052^{* * *}$ & $0.076^{* * *}$ & $0.060^{* * *}$ \\
\hline & $(14.14)$ & $(6.66)$ & $(15.29)$ & $(7.90)$ \\
\hline \multirow[t]{2}{*}{ Married } & -0.005 & $-0.080^{* * *}$ & $0.013^{* * *}$ & $-0.073^{* * *}$ \\
\hline & $(-0.98)$ & $(-3.41)$ & $(2.68)$ & $(-3.01)$ \\
\hline \multirow[t]{2}{*}{ Age } & $0.018^{* * *}$ & 0.005 & $0.020^{* * *}$ & 0.004 \\
\hline & $(12.17)$ & $(1.01)$ & $(12.79)$ & $(0.77)$ \\
\hline \multirow[t]{2}{*}{ Age sq./100 } & $-0.018^{* * *}$ & -0.005 & $-0.020^{* * *}$ & -0.005 \\
\hline & $(-11.94)$ & $(-1.19)$ & $(-12.70)$ & $(-1.00)$ \\
\hline \multirow[t]{2}{*}{ Born 1924-1932 } & -0.016 & $-0.022^{*}$ & -0.004 & -0.012 \\
\hline & $(-1.61)$ & $(-1.82)$ & $(-0.39)$ & $(-0.99)$ \\
\hline \multirow[t]{2}{*}{ Born 1933-1941 } & -0.018 & $-0.029^{*}$ & -0.004 & -0.019 \\
\hline & $(-1.39)$ & $(-1.92)$ & $(-0.32)$ & $(-1.19)$ \\
\hline \multirow[t]{2}{*}{ Born 1942-1950 } & -0.015 & -0.027 & 0.003 & -0.007 \\
\hline & $(-0.90)$ & $(-1.45)$ & $(0.17)$ & $(-0.35)$ \\
\hline \multirow[t]{2}{*}{ Born 1951-1959 } & -0.009 & -0.019 & 0.005 & -0.003 \\
\hline & $(-0.44)$ & $(-0.86)$ & $(0.21)$ & $(-0.11)$ \\
\hline \multirow[t]{2}{*}{ Born 1960-1968 } & 0.012 & -0.001 & 0.027 & 0.015 \\
\hline & $(0.49)$ & $(-0.02)$ & $(1.00)$ & $(0.51)$ \\
\hline \multirow[t]{2}{*}{ Born 1969-1978 } & 0.021 & 0.004 & 0.044 & 0.026 \\
\hline & $(0.70)$ & $(0.12)$ & $(1.39)$ & $(0.76)$ \\
\hline \multirow[t]{2}{*}{ Constant } & $1.02^{* * *}$ & 0.18 & $0.68^{* * *}$ & -0.67 \\
\hline & $(12.34)$ & $(0.29)$ & $(6.96)$ & $(-0.91)$ \\
\hline Adj. R sq. & 0.690 & 0.652 & 0.648 & 0.597 \\
\hline $\mathrm{F}$ & 2224.2 & 1122.4 & 1836.7 & 970.5 \\
\hline $\mathrm{N}$ & 42,945 & 42,911 & 42,945 & 42,911 \\
\hline
\end{tabular}


Table A-3: Risk Sharing Regressions. Total (Imputed) Nondurable Consumption.

\begin{tabular}{|c|c|c|c|c|c|c|c|c|}
\hline & \multicolumn{4}{|c|}{ Owners } & \multicolumn{4}{|c|}{ Renters } \\
\hline & (1) & $(2)$ & $(3)$ & (4) & $(5)$ & $(6)$ & (7) & (8) \\
\hline Income $\mathrm{G}$. & $\begin{array}{c}0.115^{* * *} \\
(9.04)\end{array}$ & $\begin{array}{c}0.118^{* * *} \\
(8.31)\end{array}$ & $\begin{array}{c}0.114^{* * *} \\
(8.88)\end{array}$ & & $\begin{array}{c}0.204^{* * *} \\
(11.13)\end{array}$ & $\begin{array}{c}0.192^{* * *} \\
(10.23)\end{array}$ & $\begin{array}{c}0.203^{* * *} \\
(10.92)\end{array}$ & \\
\hline House price G. & $\begin{array}{c}0.075^{* *} \\
(2.39)\end{array}$ & $\begin{array}{c}0.077^{* *} \\
(2.31)\end{array}$ & $\begin{array}{c}0.076^{* *} \\
(2.39)\end{array}$ & $\begin{array}{c}0.090^{* * *} \\
(2.64)\end{array}$ & $\begin{array}{c}0.199^{* * *} \\
(2.79)\end{array}$ & $\begin{array}{c}0.193^{* * *} \\
(2.83)\end{array}$ & $\begin{array}{c}0.195^{* * *} \\
(2.90)\end{array}$ & $\begin{array}{c}0.227^{* * *} \\
(3.21)\end{array}$ \\
\hline Inc. G. $x$ House price G. & $\begin{array}{c}-0.214^{* *} \\
(-2.27)\end{array}$ & & & & $\begin{array}{l}-0.067 \\
(-0.42)\end{array}$ & & & \\
\hline Displaced & & $\begin{array}{l}-0.021 \\
(-1.17)\end{array}$ & & $\begin{array}{c}-0.033^{*} \\
(-1.80)\end{array}$ & & $\begin{array}{c}-0.071 * * * \\
(-2.75)\end{array}$ & & $\begin{array}{c}-0.098^{* * *} \\
(-3.73)\end{array}$ \\
\hline Displaced x House price G. & & $\begin{array}{l}0.128 \\
(1.00)\end{array}$ & & $\begin{array}{c}0.101 \\
(0.78)\end{array}$ & & $\begin{array}{c}0.142 \\
(0.75)\end{array}$ & & $\begin{array}{c}0.135 \\
(0.69)\end{array}$ \\
\hline Disabled & & & $\begin{array}{c}-0.059 * * * \\
(-3.03)\end{array}$ & $\begin{array}{c}-0.064^{* * *} \\
(-3.12)\end{array}$ & & & $\begin{array}{c}-0.047^{*} \\
(-1.81)\end{array}$ & $\begin{array}{c}-0.055^{*} \\
(-1.89)\end{array}$ \\
\hline Disability x House price G. & & & $\begin{array}{c}0.295^{* * *} \\
(2.76)\end{array}$ & $\begin{array}{c}0.317^{* * *} \\
(2.73)\end{array}$ & & & $\begin{array}{l}-0.149 \\
(-0.64)\end{array}$ & $\begin{array}{l}-0.170 \\
(-0.67)\end{array}$ \\
\hline Fam. size G. & $\begin{array}{c}0.223^{* * *} \\
(11.30)\end{array}$ & $\begin{array}{c}0.230^{* * *} \\
(11.45)\end{array}$ & $\begin{array}{c}0.223^{* * *} \\
(11.27)\end{array}$ & $\begin{array}{c}0.234^{* * *} * \\
(11.60)\end{array}$ & $\begin{array}{c}0.166^{* * *} \\
(5.39)\end{array}$ & $\begin{array}{c}0.178^{* * *} \\
(5.66)\end{array}$ & $\begin{array}{c}0.166^{* * *} \\
(5.42)\end{array}$ & $\begin{array}{c}0.186^{* * *} \\
(6.53)\end{array}$ \\
\hline Age & $\begin{array}{c}-0.014^{* * *} \\
(-3.28)\end{array}$ & $\begin{array}{c}-0.013^{* * *} \\
(-2.81)\end{array}$ & $\begin{array}{c}-0.014^{* * *} \\
(-3.29)\end{array}$ & $\begin{array}{c}-0.009^{* *} \\
(-2.05)\end{array}$ & $\begin{array}{l}-0.004 \\
(-0.46)\end{array}$ & $\begin{array}{l}-0.004 \\
(-0.55)\end{array}$ & $\begin{array}{l}-0.004 \\
(-0.48)\end{array}$ & $\begin{array}{l}-0.006 \\
(-0.81)\end{array}$ \\
\hline Age sq./100 & $\begin{array}{c}0.011^{* *} \\
(2.36)\end{array}$ & $\begin{array}{c}0.010^{*} \\
(1.97)\end{array}$ & $\begin{array}{c}0.011^{* *} \\
(2.38)\end{array}$ & $\begin{array}{l}0.005 \\
(1.01)\end{array}$ & $\begin{array}{l}0.001 \\
(0.08)\end{array}$ & $\begin{array}{l}0.001 \\
(0.12)\end{array}$ & $\begin{array}{l}0.001 \\
(0.10)\end{array}$ & $\begin{array}{l}0.001 \\
(0.16)\end{array}$ \\
\hline $\begin{array}{l}\text { Adj. R sq. } \\
\text { F }\end{array}$ & 0.050 & 0.050 & 0.051 & 0.039 & 0.046 & 0.047 & 0.047 & 0.023 \\
\hline $\begin{array}{l}\mathrm{F} \\
\mathrm{N}\end{array}$ & $\begin{array}{c}87.5 \\
11,846\end{array}$ & $\begin{array}{c}65.5 \\
10,983\end{array}$ & $\begin{array}{c}83.0 \\
11,846\end{array}$ & $\begin{array}{c}55.8 \\
10,983\end{array}$ & $\begin{array}{c}39.8 \\
4,345\end{array}$ & $\begin{array}{c}38.2 \\
4,102\end{array}$ & $\begin{array}{c}35.6 \\
4,345\end{array}$ & $\begin{array}{c}21.8 \\
4,102\end{array}$ \\
\hline
\end{tabular}

Notes: See notes to Table 2. Regressions use the residual measure of house-price appreciation as in Table 6.

t-statistics in parentheses. $* * *$ significant at the $1 \%$ level, $* *$ significant at the $5 \%$ level, ${ }^{*}$ significant at the $10 \%$ level. 
Table A-4: Risk Sharing Regressions. Wealth-Rich vs. Wealth-Poor

\begin{tabular}{|c|c|c|c|c|c|c|c|c|}
\hline & \multicolumn{4}{|c|}{ RICH } & \multicolumn{4}{|c|}{ POOR } \\
\hline & \multicolumn{2}{|c|}{ Owner } & \multicolumn{2}{|c|}{ Renter } & \multicolumn{2}{|c|}{ Owner } & \multicolumn{2}{|c|}{ Renter } \\
\hline & $(1)$ & $(2)$ & $(3)$ & $(4)$ & $(5)$ & $(6)$ & $(7)$ & $(8)$ \\
\hline Income G. & $\begin{array}{c}0.092^{* * *} \\
(7.91)\end{array}$ & $\begin{array}{c}0.090^{* * *} \\
(8.08)\end{array}$ & $\begin{array}{c}0.111^{* * *} \\
(3.13)\end{array}$ & $\begin{array}{c}0.122^{* * *} \\
(3.74)\end{array}$ & $\begin{array}{c}0.135^{* * *} \\
(4.49)\end{array}$ & $\begin{array}{c}0.135^{* * *} \\
(4.84)\end{array}$ & $\begin{array}{c}0.232^{* * *} \\
(9.39)\end{array}$ & $\begin{array}{c}0.235^{* * *} \\
(10.19)\end{array}$ \\
\hline House price G. & $\begin{array}{c}0.112^{* * *} \\
(3.93)\end{array}$ & $\begin{array}{c}0.112^{* * *} \\
(3.94)\end{array}$ & $\begin{array}{c}-0.111^{*} \\
(-1.84)\end{array}$ & $\begin{array}{l}-0.099 \\
(-1.57)\end{array}$ & $\begin{array}{l}0.090 \\
(1.38)\end{array}$ & $\begin{array}{l}0.091 \\
(1.41)\end{array}$ & $\begin{array}{c}0.109 \\
(1.51)\end{array}$ & $\begin{array}{l}0.107 \\
(1.47)\end{array}$ \\
\hline Displaced & $\begin{array}{c}-0.051^{* * *} \\
(-4.23)\end{array}$ & & $\begin{array}{c}-0.063^{*} \\
(-1.91)\end{array}$ & & $\begin{array}{l}-0.001 \\
(-0.02)\end{array}$ & & $\begin{array}{c}-0.065^{* *} \\
(-2.30)\end{array}$ & \\
\hline Displaced x House price G. & $\begin{array}{c}0.187^{*} \\
(1.69)\end{array}$ & & $\begin{array}{l}0.007 \\
(0.04)\end{array}$ & & $\begin{array}{l}-0.135 \\
(-0.69)\end{array}$ & & $\begin{array}{l}0.090 \\
(0.55)\end{array}$ & \\
\hline Disabled & & $\begin{array}{c}-0.032^{* *} \\
(-2.07)\end{array}$ & & $\begin{array}{l}-0.007 \\
(-0.10)\end{array}$ & & $\begin{array}{l}-0.018 \\
(-0.65)\end{array}$ & & $\begin{array}{c}-0.066^{*} \\
(-1.83)\end{array}$ \\
\hline Disability x House price G. & & $\begin{array}{l}0.101 \\
(1.08)\end{array}$ & & $\begin{array}{l}-0.283 \\
(-0.53)\end{array}$ & & $\begin{array}{c}0.446^{* *} \\
(2.24)\end{array}$ & & $\begin{array}{l}-0.163 \\
(-0.74)\end{array}$ \\
\hline Fam. size G. & $\begin{array}{c}0.349^{* * *} \\
(15.51)\end{array}$ & $\begin{array}{c}0.346^{* * *} \\
(15.38)\end{array}$ & $\begin{array}{c}0.315^{* * *} \\
(4.73)\end{array}$ & $\begin{array}{c}0.293^{* * *} \\
(4.38)\end{array}$ & $\begin{array}{c}0.259^{* * *} \\
(7.42)\end{array}$ & $\begin{array}{c}0.272^{* * *} \\
(8.12)\end{array}$ & $\begin{array}{c}0.234^{* * *} \\
(8.24)\end{array}$ & $\begin{array}{c}0.231^{* * *} \\
(8.09)\end{array}$ \\
\hline Age & $\begin{array}{c}-0.008^{*} \\
(-1.69)\end{array}$ & $\begin{array}{c}-0.008^{*} \\
(-1.70)\end{array}$ & $\begin{array}{l}0.007 \\
(0.51)\end{array}$ & $\begin{array}{l}0.007 \\
(0.51)\end{array}$ & $\begin{array}{c}-0.034^{* * *} \\
(-2.81)\end{array}$ & $\begin{array}{c}-0.035^{* * *} \\
(-2.89)\end{array}$ & $\begin{array}{l}-0.008 \\
(-0.93)\end{array}$ & $\begin{array}{l}-0.009 \\
(-1.05)\end{array}$ \\
\hline Age sq./100 & $\begin{array}{l}0.004 \\
(0.91)\end{array}$ & $\begin{array}{l}0.004 \\
(0.90)\end{array}$ & $\begin{array}{l}-0.012 \\
(-0.81)\end{array}$ & $\begin{array}{l}-0.013 \\
(-0.78)\end{array}$ & $\begin{array}{c}0.032^{* *} \\
(2.56)\end{array}$ & $\begin{array}{c}0.033^{* * *} \\
(2.63)\end{array}$ & $\begin{array}{l}0.005 \\
(0.58)\end{array}$ & $\begin{array}{l}0.007 \\
(0.79)\end{array}$ \\
\hline Adj. R sq. & 0.100 & 0.098 & 0.087 & 0.081 & 0.067 & 0.074 & 0.065 & 0.065 \\
\hline $\mathrm{F}$ & 124.0 & 141.7 & 13.0 & 8.6 & 29.5 & 39.8 & 75.6 & 54.5 \\
\hline $\mathrm{N}$ & 8,578 & 9,027 & 1,053 & 1,083 & 2,328 & 2,443 & 3,479 & 3,561 \\
\hline
\end{tabular}

Notes: See notes to Table 2. Households are labeled "rich" if their liquid wealth (total net worth excluding housing equity and business wealth) in 1984 is above the 60th percentile of the wealth distribution in 1984. "Poor" households are those whose liquid wealth in 1984 is below the 40th percentile of the liquid wealth distribution in 1984. Regressions use the residual measure of house-price appreciation as in Table 6 . t-statistics in parentheses. ${ }^{* * *}$ significant at the $1 \%$ level, $* *$ significant at the $5 \%$ level, * significant at the $10 \%$ level. 
Table A-5: Risk Sharing Regressions. Credit Conditions on Installment Loans

\begin{tabular}{|c|c|c|c|c|}
\hline & \multicolumn{2}{|c|}{ Owners } & \multicolumn{2}{|c|}{ Renters } \\
\hline & $(1)$ & $(2)$ & $(3)$ & $(4)$ \\
\hline Income G. & $\begin{array}{c}0.097^{* * *} \\
(10.10)\end{array}$ & $\begin{array}{c}0.096^{* * *} \\
(10.86)\end{array}$ & $\begin{array}{c}0.168^{* * *} \\
(11.02)\end{array}$ & $\begin{array}{c}0.177^{* * *} \\
(11.57)\end{array}$ \\
\hline Credit Conditions & $\begin{array}{l}-0.034 \\
(-1.37)\end{array}$ & $\begin{array}{l}-0.030 \\
(-1.26)\end{array}$ & $\begin{array}{c}0.070^{* *} \\
(1.99)\end{array}$ & $\begin{array}{c}0.062^{*} \\
(1.76)\end{array}$ \\
\hline Displaced & $\begin{array}{c}-0.038 * * * \\
(-3.04)\end{array}$ & & $\begin{array}{c}-0.059^{* * *} \\
(-3.44)\end{array}$ & \\
\hline Displaced x Credit Conditions & $\begin{array}{l}-0.025 \\
(-0.32)\end{array}$ & & $\begin{array}{l}-0.004 \\
(-0.04)\end{array}$ & \\
\hline Disabled & & $\begin{array}{c}-0.032^{* * *} \\
(-2.80)\end{array}$ & & $\begin{array}{c}-0.044^{* *} \\
(-2.06)\end{array}$ \\
\hline Disability x Credit Conditions & & $\begin{array}{l}0.069 \\
(0.82)\end{array}$ & & $\begin{array}{l}0.108 \\
(0.87)\end{array}$ \\
\hline Fam. size G. & $\begin{array}{c}0.334^{* * *} \\
(22.68)\end{array}$ & $\begin{array}{c}0.332^{* * * *} \\
(22.94)\end{array}$ & $\begin{array}{c}0.257^{* * * *} \\
(14.11)\end{array}$ & $\begin{array}{c}0.251^{* * *} \\
(14.07)\end{array}$ \\
\hline Age & $\begin{array}{c}-0.006^{*} \\
(-1.71)\end{array}$ & $\begin{array}{c}-0.007^{* *} \\
(-2.09)\end{array}$ & $\begin{array}{l}0.002 \\
(0.45)\end{array}$ & $\begin{array}{l}0.002 \\
(0.54)\end{array}$ \\
\hline Age sq./100 & $\begin{array}{l}0.002 \\
(0.68)\end{array}$ & $\begin{array}{l}0.004 \\
(1.02)\end{array}$ & $\begin{array}{l}-0.005 \\
(-1.15)\end{array}$ & $\begin{array}{l}-0.005 \\
(-1.14)\end{array}$ \\
\hline Adj. R sq. & 0.089 & 0.088 & 0.059 & 0.059 \\
\hline $\mathrm{F}$ & 123.2 & 189.2 & 77.8 & 87.4 \\
\hline $\mathrm{N}$ & 16298 & 17283 & 7204 & 7489 \\
\hline
\end{tabular}

Notes: In column (1), we run the regression: $c_{i t}-\bar{c}_{t}=\mu+\alpha\left(y_{i t}-\bar{y}_{t}\right)+\beta\left(b_{t}-\bar{b}\right)+\gamma\left(y_{i t}-\bar{y}_{t}\right) \times\left(b_{t}-\bar{b}\right)+\left(X_{i t}-\bar{X}_{t}\right)^{\prime} \delta+\varepsilon_{i t}$, where $c_{i t}$ is the 4-year $\log$ difference of consumption for individual $i$ in year $t, y_{i t}$ is the 4-year log difference of income, and $\bar{y}_{t}$ is the mean 4-year $\log$ income difference in period $t ; b_{t}$ is a variable summarizing credit conditions on installment loans. Similar regressions for other columns. Owners own a house between years $t$ and $t-4$; renters continuously rent a house between years $t$ and $t-4$. All resided in the same MSA and did not change family composition during that time span. Serial correlation in the regression errors is corrected using the Prais-Winsten transformation; standard errors in the regressions are clustered by the MSA where the household lives between years $t$ and $t-4$. t-statistics in parentheses. ${ }^{* * *}$ significant at the $1 \%$ level, ${ }^{* *}$ significant at the $5 \%$ level, ${ }^{*}$ significant at the $10 \%$ level. 
Table B-1: Risk Sharing Regressions in the Model. Permanent and Transitory Displacement Shocks

\begin{tabular}{|c|c|c|c|c|c|c|}
\hline & \multicolumn{2}{|c|}{ All } & \multicolumn{2}{|c|}{ Owners } & \multicolumn{2}{|c|}{ Renters } \\
\hline & $(1)$ & $(2)$ & $(3)$ & $(4)$ & $(5)$ & $(6)$ \\
\hline Income Growth & $\begin{array}{c}0.16^{* * *} \\
(177.19)\end{array}$ & $\begin{array}{c}0.15^{* * *} \\
(83.16)\end{array}$ & $\begin{array}{c}0.11^{* * *} \\
(209.97)\end{array}$ & $\begin{array}{c}0.10^{* * *} \\
(104.84)\end{array}$ & $\begin{array}{c}0.30^{* * *} \\
(178.91)\end{array}$ & $\begin{array}{l}0.30^{* * *} \\
(178.75)\end{array}$ \\
\hline House Price Growth & $\begin{array}{l}0.15^{* * *} \\
(100.15)\end{array}$ & $\begin{array}{l}0.15^{* * *} \\
(103.29)\end{array}$ & $\begin{array}{l}0.22^{* * *} \\
(151.37)\end{array}$ & $\begin{array}{l}0.22^{* * *} \\
(152.31)\end{array}$ & $\begin{array}{c}0.00 \\
(0.82)\end{array}$ & $\begin{array}{c}0.00 \\
(1.24)\end{array}$ \\
\hline Income G. x House Price G. & $\begin{array}{c}-0.04^{* * *} \\
(-18.12)\end{array}$ & & $\begin{array}{c}-0.02^{* * *} \\
(-16.08)\end{array}$ & & $\begin{array}{l}0.01^{*} \\
(1.83)\end{array}$ & \\
\hline Displaced & & $\begin{array}{c}-0.05^{* * *} \\
(-32.16)\end{array}$ & & $\begin{array}{c}-0.05^{* * *} \\
(-35.83)\end{array}$ & & $\begin{array}{c}-0.05^{* * *} \\
(-20.07)\end{array}$ \\
\hline Displaced x House Price G. & & $\begin{array}{c}0.03^{* * *} \\
(8.11)\end{array}$ & & $\begin{array}{c}0.03^{* * *} \\
(8.50)\end{array}$ & & $\begin{array}{c}-0.01 \\
(-0.72)\end{array}$ \\
\hline Age & $\begin{array}{c}-0.01^{* * *} \\
(-37.90)\end{array}$ & $\begin{array}{c}-0.01 * * * \\
(-40.36)\end{array}$ & $\begin{array}{c}0.01^{* * *} \\
(43.56)\end{array}$ & $\begin{array}{c}0.01^{* * *} \\
(43.02)\end{array}$ & $\begin{array}{c}-0.04^{* * *} \\
(-48.16)\end{array}$ & $\begin{array}{c}-0.04^{* * *} \\
(-47.47)\end{array}$ \\
\hline Age sq./100 & $\begin{array}{c}0.01^{* * *} \\
(29.70)\end{array}$ & $\begin{array}{c}0.01^{* * *} \\
(31.04)\end{array}$ & $\begin{array}{c}-0.01^{* * *} \\
(-37.76)\end{array}$ & $\begin{array}{c}-0.01^{* * *} \\
(-36.85)\end{array}$ & $\begin{array}{c}0.04^{* * *} \\
(39.78)\end{array}$ & $\begin{array}{c}0.04^{* * *} \\
(39.12)\end{array}$ \\
\hline Adj. R sq. & 0.287 & 0.290 & 0.282 & 0.289 & 0.469 & 0.471 \\
\hline $\mathrm{F}$ & 16038.6 & 9948.5 & 15375.9 & 12168.3 & 11495.4 & 7121.2 \\
\hline $\mathrm{N}$ & 274291 & 274291 & 180335 & 180335 & 64518 & 64518 \\
\hline
\end{tabular}

Notes: See notes to Table 14. Mixed of permanent and transitory displacement shocks. Permanent (transitory) shocks occur with a $1 \%(5 \%)$ annual probability and reduce income by $25 \%$ (60\%). This combination of shocks results in a mean for the displacement dummy of .116 and a standard deviation of .32, matching PSID data in Table 1. Parameters recalibrated appropriately. Discount rate: 3.17\%; minimum house size: 1.62; housing share parameter in the utility function: .2 .

Prais-Winsten regressions. Robust standard errors in the regressions clustered by region. t-statistics in parentheses. *** significant at the $1 \%$ level, ** significant at the $5 \%$ level, $*$ significant at the $10 \%$ level. 
Table B-2: Risk Sharing Regressions in the Model. CES utility

\begin{tabular}{|c|c|c|c|c|}
\hline & \multicolumn{2}{|c|}{ No bequest or Correlation } & \multicolumn{2}{|c|}{ Bequest and Correlation } \\
\hline & $\begin{array}{c}\text { Owner } \\
(1)\end{array}$ & $\begin{array}{c}\text { Renter } \\
(2)\end{array}$ & $\begin{array}{c}\text { Owner } \\
(3)\end{array}$ & $\begin{array}{c}\text { Renter } \\
(4)\end{array}$ \\
\hline Income Growth & $\begin{array}{l}0.11^{* * *} \\
(200.90)\end{array}$ & $\begin{array}{l}0.27 * * * \\
(179.73)\end{array}$ & $\begin{array}{l}0.11^{* * *} \\
(196.22)\end{array}$ & $\begin{array}{l}0.20^{* * *} \\
(134.97)\end{array}$ \\
\hline House Price Growth & $\begin{array}{c}0.22^{* * *} \\
(123.89)\end{array}$ & $\begin{array}{c}-0.00 \\
(-0.12)\end{array}$ & $\begin{array}{c}0.36^{* * *} \\
(176.79)\end{array}$ & $\begin{array}{c}0.15^{* * *} \\
(48.12)\end{array}$ \\
\hline Income G. $\times$ House Price G. & $\begin{array}{c}-0.02^{* * *} \\
(-15.34)\end{array}$ & $\begin{array}{c}0.01^{* * *} \\
(2.79)\end{array}$ & $\begin{array}{c}-0.01^{* * *} \\
(-4.37)\end{array}$ & $\begin{array}{c}-0.01 \\
(-1.52)\end{array}$ \\
\hline Displaced & $\begin{array}{l}-0.16^{* * *} \\
(-136.68)\end{array}$ & $\begin{array}{c}-0.20^{* * *} \\
(-43.79)\end{array}$ & $\begin{array}{l}-0.15^{* * *} \\
(-150.82)\end{array}$ & $\begin{array}{c}-0.20^{* * *} \\
(-65.33)\end{array}$ \\
\hline Displaced $\times$ House Price G. & $\begin{array}{c}0.03^{* * *} \\
(9.20)\end{array}$ & $\begin{array}{c}0.01 \\
(0.84)\end{array}$ & $\begin{array}{c}0.02^{* * *} \\
(5.60)\end{array}$ & $\begin{array}{l}0.02^{*} \\
(1.73)\end{array}$ \\
\hline Age & $\begin{array}{c}0.01^{* * *} \\
(20.47)\end{array}$ & $\begin{array}{c}-0.04^{* * *} \\
(-48.18)\end{array}$ & $\begin{array}{c}0.01^{* * *} \\
(21.77)\end{array}$ & $\begin{array}{c}0.01^{* * *} \\
(10.40)\end{array}$ \\
\hline Age sq./100 & $\begin{array}{c}-0.01^{* * *} \\
(-20.50)\end{array}$ & $\begin{array}{l}0.04^{* * *} \\
(40.47)\end{array}$ & $\begin{array}{c}-0.01^{* * *} \\
(-23.40)\end{array}$ & $\begin{array}{c}-0.01^{* * *} \\
(-11.41)\end{array}$ \\
\hline $\begin{array}{l}\text { Adj. R sq. } \\
\text { F }\end{array}$ & $\begin{array}{c}0.347 \\
24416\end{array}$ & $\begin{array}{c}0.444 \\
0262 ?\end{array}$ & $\begin{array}{c}0.459 \\
223946\end{array}$ & 0.359 \\
\hline $\begin{array}{l}\mathrm{F} \\
\mathrm{N}\end{array}$ & $\begin{array}{l}24410.1 \\
179,606\end{array}$ & $\begin{array}{l}9202.2 \\
62,398\end{array}$ & $\begin{array}{l}22594.0 \\
160841\end{array}$ & 81985 \\
\hline
\end{tabular}

Notes: See notes to Table 14. Parameters recalibrated appropriately. Discount rate with no bequest or correlation (bequest and correlation): 2.95\% (4.02\%); minimum house size: 1.64 (.167); bequest parameter: 0 (1.0). In both cases the housing share parameter in the utility function is 0.62 and the intratemporal elasticity of substitution is 0.32 as estimated in ?.

Prais-Winsten regressions. Robust standard errors in the regressions clustered by region. t-statistics in parentheses. *** significant at the $1 \%$ level, ** significant at the $5 \%$ level, * significant at the $10 \%$ level. 
FiguRE 1: MSA house-price appreciation (4-year growth rates)

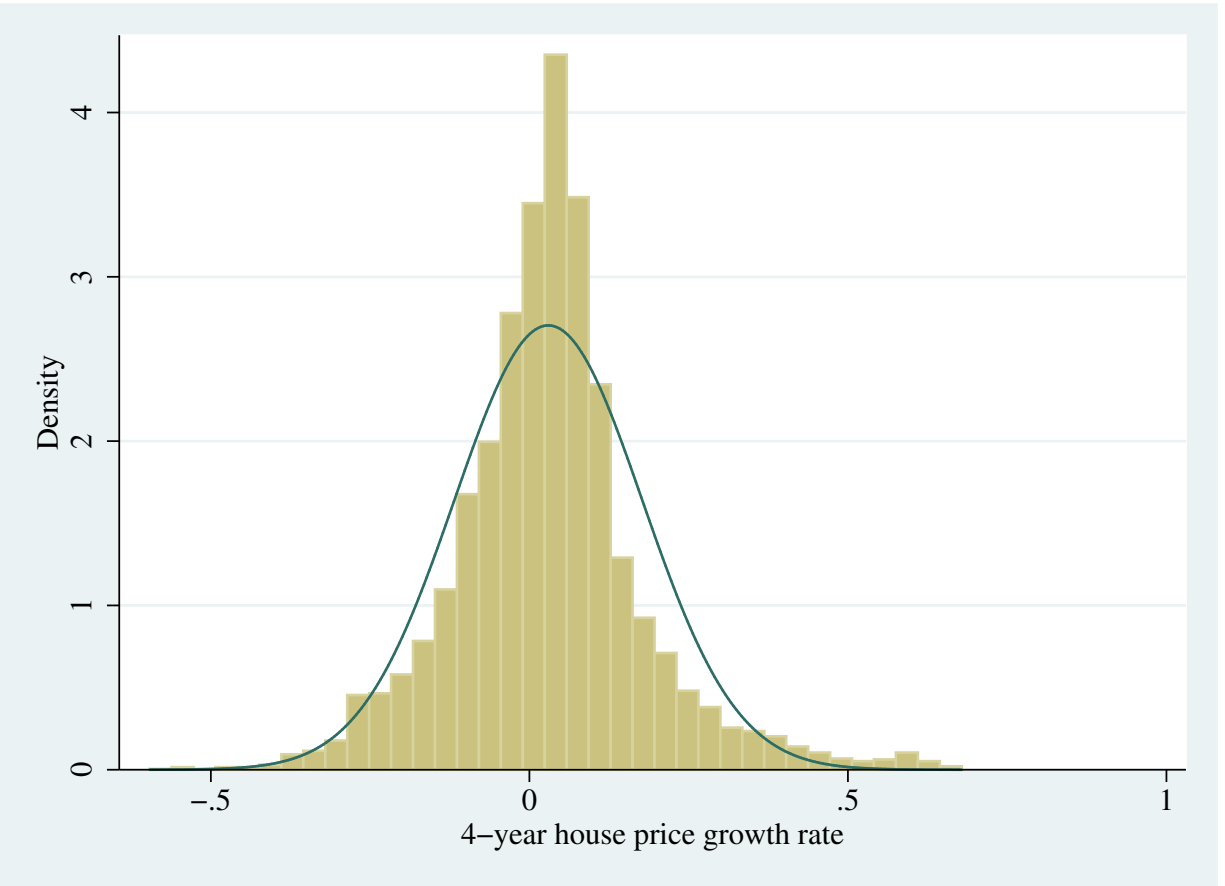


Figure 2: MSA house-price appreciation. Selected MSAs

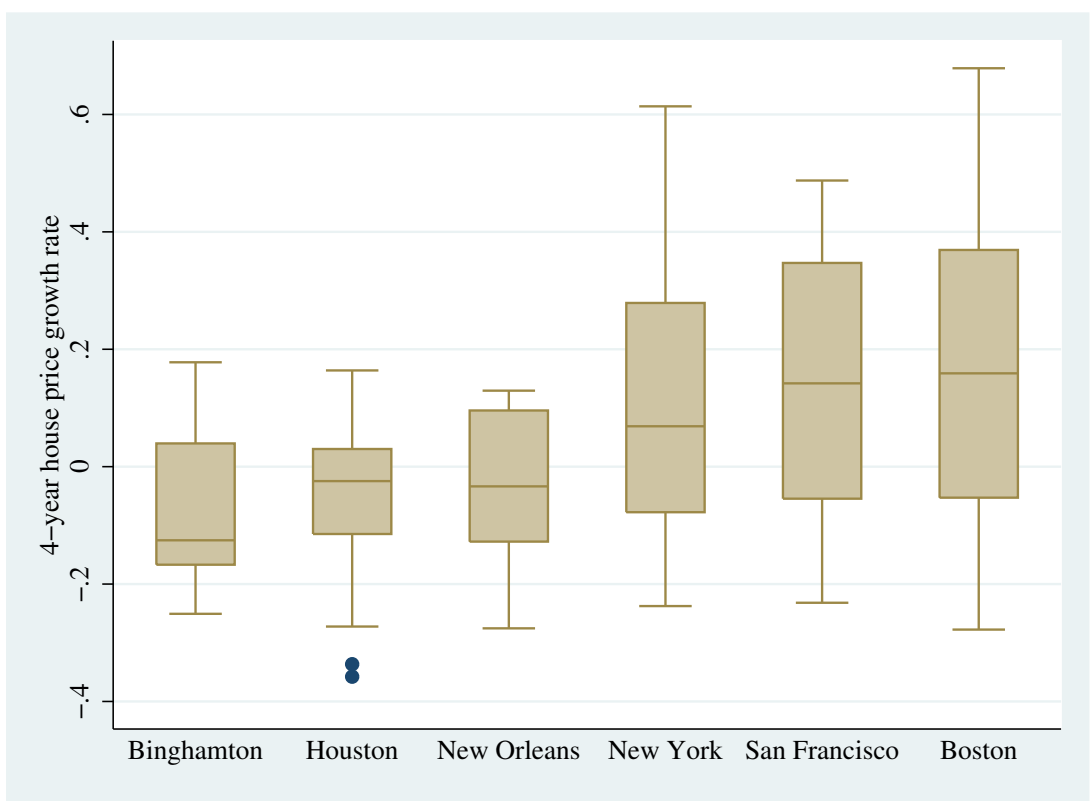

(a) Low vs. High

On each box, the central mark is the median, the edges of the box are the 25th and 75th percentiles, the whiskers extend to the most extreme data points not considered outliers, and outliers are plotted individually.

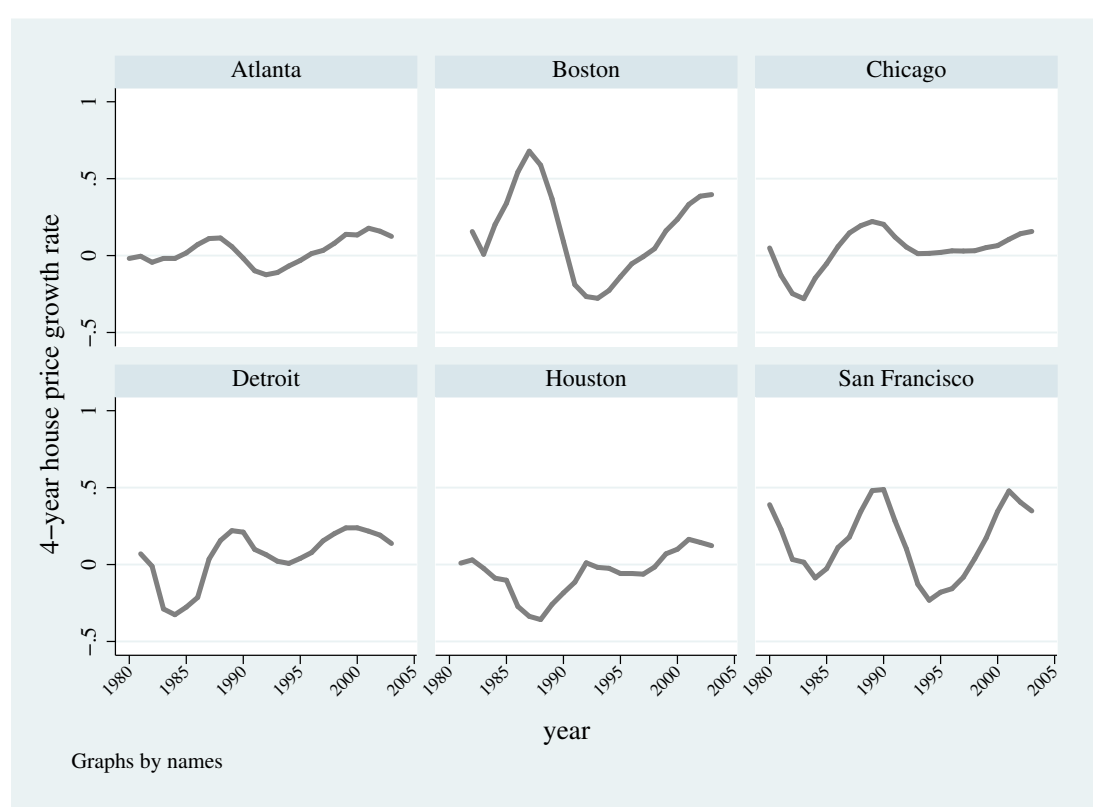

(b) Over Time 
Figure 3: Life-cycle Profiles. The Benchmark Case

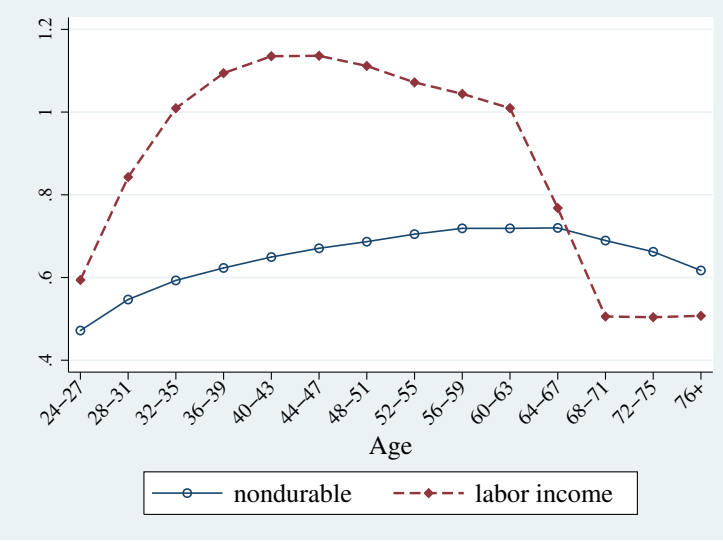

(a) Income and Consumption

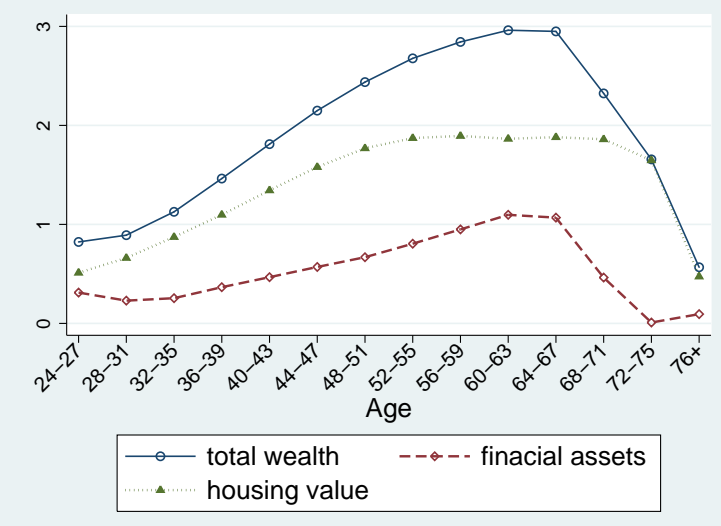

(b) Wealth 
Figure 4: The Benchmark and the Data
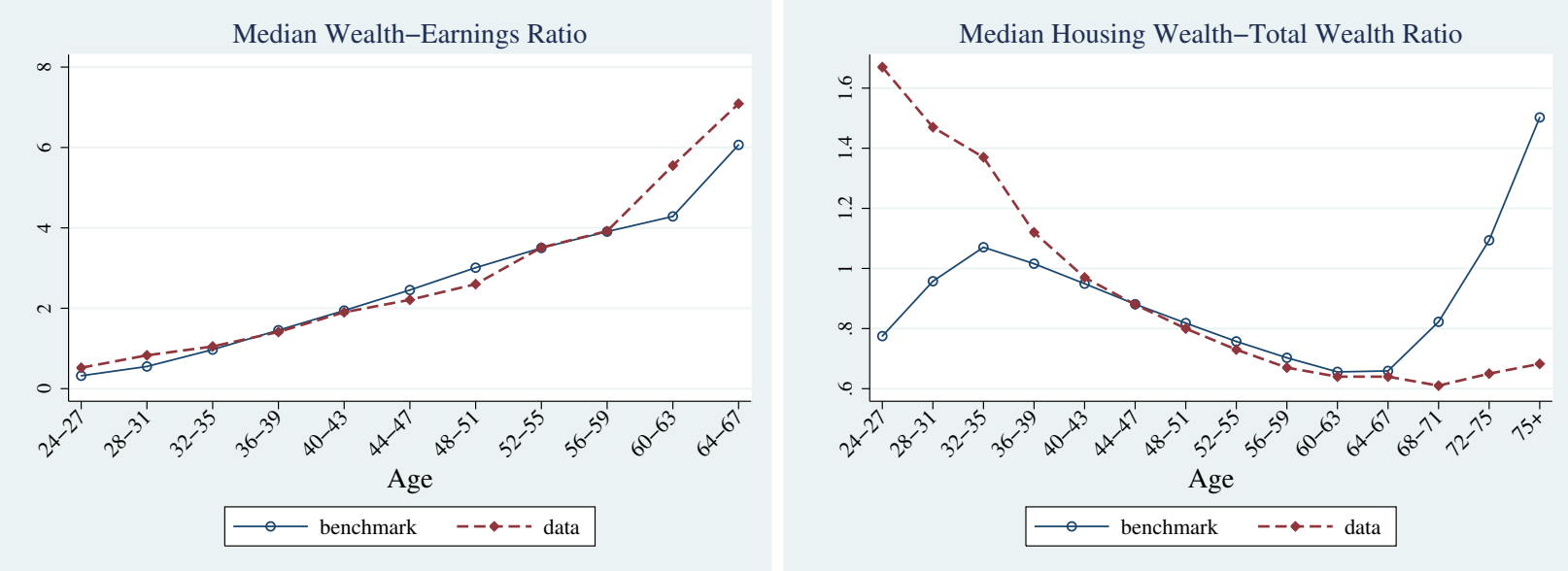

(a) Wealth and Earnings

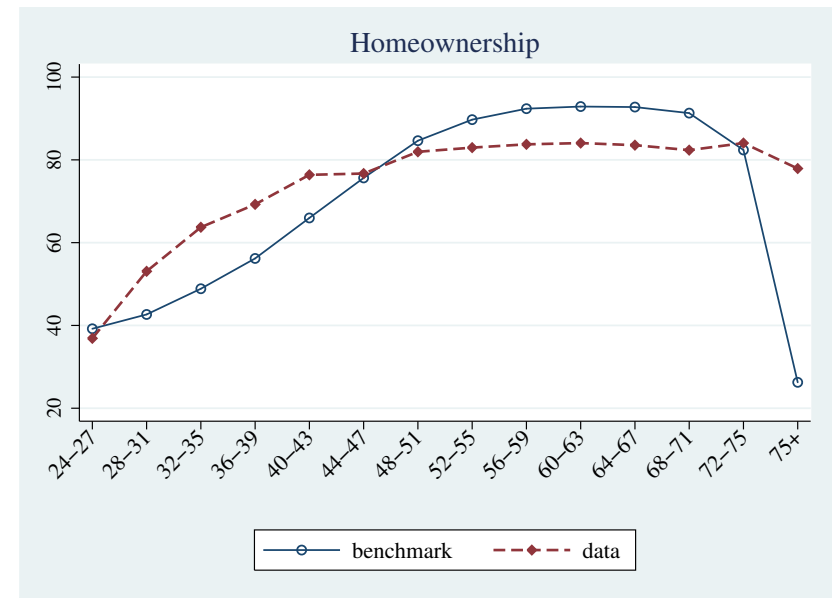

(b) Home ownership 
FIguRE 5: Home ownership under Different Assumptions

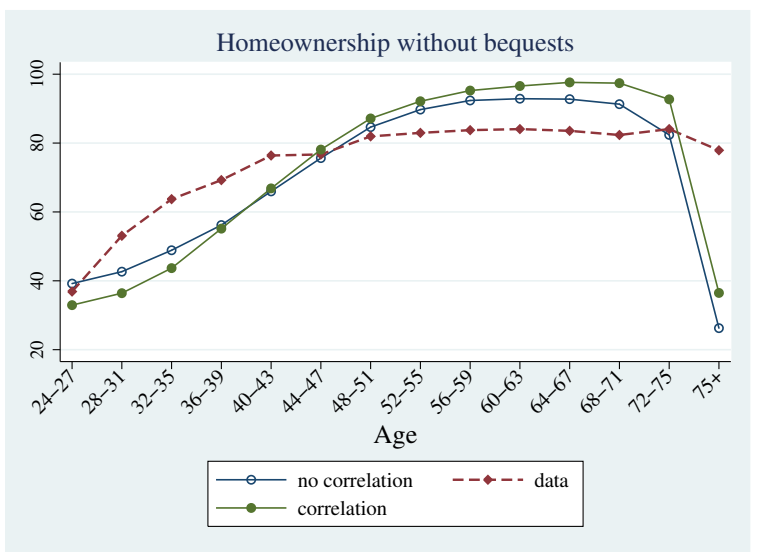

(a) Accidental Bequests

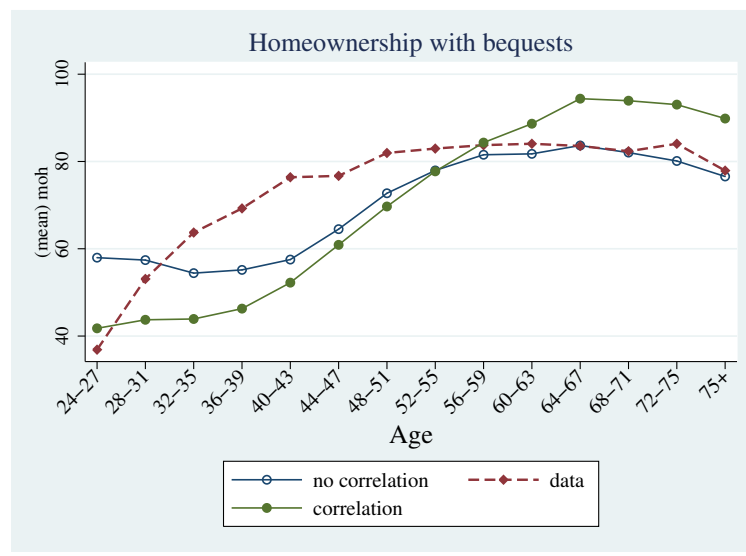

(b) Bequest Motive 